OAKRIDGE NATIONAL LABORATORY

MANAGED BY UT-BATTELLE FOR THE DEPAATAENT OF ENEAGY

\title{
THE FEDERAL HIGHWAY ADMINISTRATION GASOHOL CONSUMPTION ESTIMATION MODEL
}

\section{August 2003}

Ho-Ling Hwang

Lorena F. Truett

Stacy C. Davis

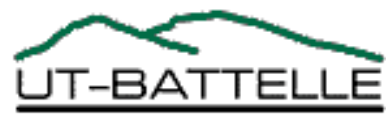




\section{DOCUMENT AVAILABILITY}

Reports produced after January 1,1996, are generally available free via the U.S. Department of Energy (DOE) Information Bridge.

Web site http://www.osti.gov/bridge

Reports produced before January 1, 1996, may be purchased by members of the public from the following source.

National Technical Information Service

5285 Port Royal Road

Springfield, VA 22161

Telephone 703-605-6000 (1-800-553-6847)

TDD 703-487-4639

Fax 703-605-6900

E-mail info@ntis.fedworld.gov

Web site http://www.ntis.gov/support/ordernowabout.htm

Reports are available to DOE employees, DOE contractors, Energy Technology Data Exchange (ETDE) representatives, and International Nuclear Information System (INIS) representatives from the following source.

Office of Scientific and Technical Information

P.O. Box 62

Oak Ridge, TN 37831

Telephone 865-576-8401

Fax 865-576-5728

E-mail reports@adonis.osti.gov

Web site http://www.osti.gov/contact.html

This report was prepared as an account of work sponsored by an agency of the United States Government. Neither the United States government nor any agency thereof, nor any of their employees, makes any warranty, express or implied, or assumes any legal liability or responsibility for the accuracy, completeness, or usefulness of any information, apparatus, product, or process disclosed, or represents that its use would not infringe privately owned rights. Reference herein to any specific commercial product, process, or service by trade name, trademark, manufacturer, or otherwise, does not necessarily constitute or imply its endorsement, recommendation, or favoring by the United States Government or any agency thereof. The views and opinions of authors expressed herein do not necessarily state or reflect those of the United States Government or any agency thereof. 


\title{
THE FEDERAL HIGHWAY ADMINISTRATION GASOHOL CONSUMPTION ESTIMATION MODEL
}

\author{
Ho-Ling Hwang \\ Tykey Truett \\ Stacy Davis \\ Center for Transportation Analysis \\ Oak Ridge National Laboratory
}

August 2003

Prepared for the

Office of Highway Policy Information

Federal Highway Administration

U.S. Department of Transportation

Washington, D.C. 20590

Prepared by the

Center for Transportation Analysis

Oak Ridge National Laboratory

Oak Ridge, Tennessee 37831

managed by

UT-Battelle, LLC

for the

U.S. Department of Energy

Under Contract No. DE-AC05-00OR22725 



\section{CONTENTS}

ABSTRACT ix

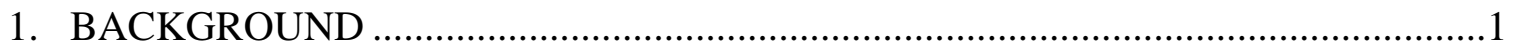

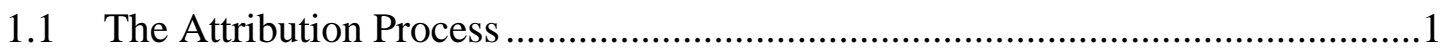

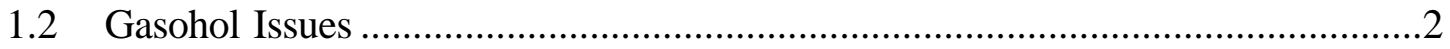

1.3 Development of the Gasohol Model.................................................................

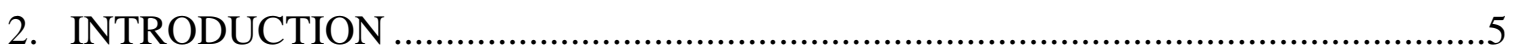

$2.1 \quad$ Purpose of This Tasking ...........................................................................5

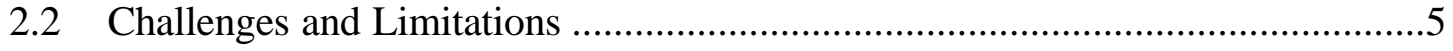

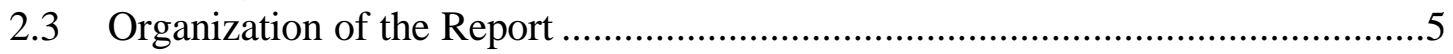

3. THE FHWA REGRESSION-BASED GASOHOL ESTIMATION MODEL ...............7

3.1 Description of the Regression-Based Model..................................................

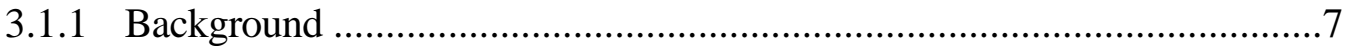

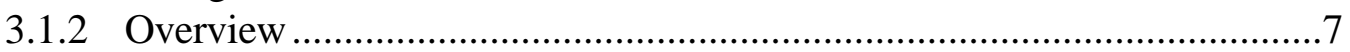

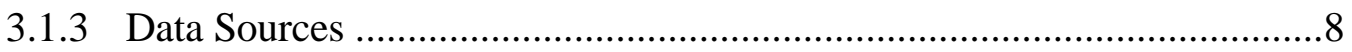

3.1.3.1 State-submitted Motor Fuel Data ..............................................

3.1.3.2 IRS Quarterly Tax Revenue Data and Tax Rates .......................9

3.1.3.3 Environmental Protection Agency Nonattainment Areas Information..................................................................

3.1.3.4 Renewable Fuels Association Reports .....................................10

3.1.3.5 State Responses to Gasohol Questionnaire ................................10

3.1.3.6 Clean Fuels Report...................................................................11

3.1.4 Description of the Regression-based Gasohol Estimation Process ..........11

3.1.4.1 Computing the Control Total..................................................11

3.1.4.2 Use of State-Provided Data......................................................12

3.1.4.3 Estimating Ethanol Gallons for Non-selected States ................12

3.1.4.4 Estimating Gasohol Gallons ……………………………......12

3.1.4.5 The Regression Estimation Method ...........................................13

3.2 Analytical Assessment of the Regression-Based Model.......................................13

3.2.1 The Spreadsheet Files .........................................................................14

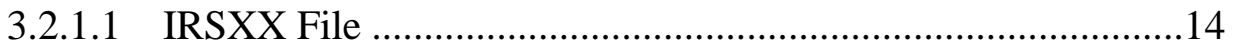

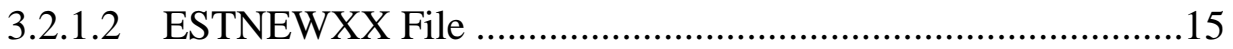

3.2.2 The Regression Equation...................................................................16

3.2.3 Inputs to the Regression Equation .........................................................16

3.2.3.1 State- level Ethanol Consumption .............................................17

3.2.3.2 Proximity to a Production Plant ..............................................17

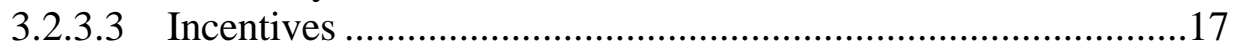

3.2.3.4 Carbon Monoxide Factor ……………………...........................17

3.2.3.5 Total Gasoline Used by State...................................................17

3.2.4 Review Comments on the Regression Equation......................................18

3.2.4.1 Proximity to a Production Plant ...............................................18 


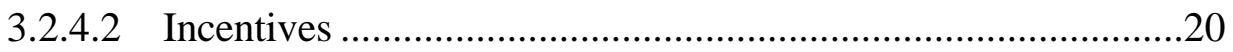

3.2.4.3 Model Formulation ..............................................................20

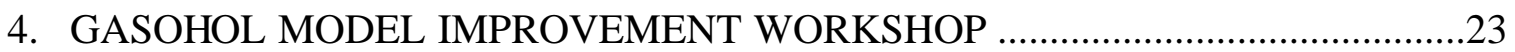

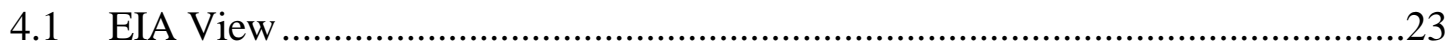

4.2 Perspective of the DOE Field Expert …………….........................................24

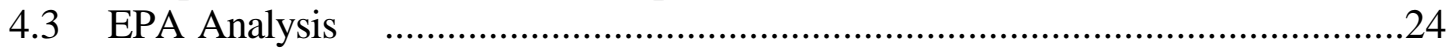

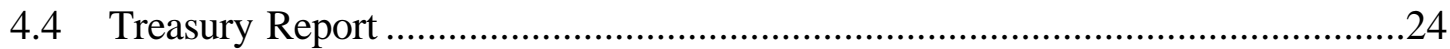

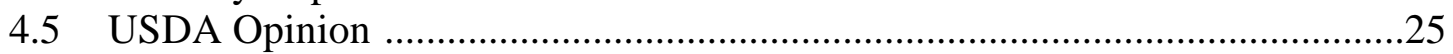

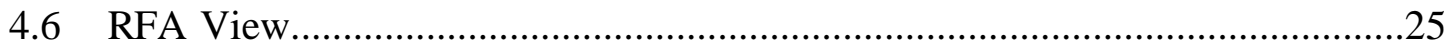

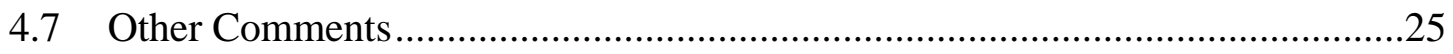

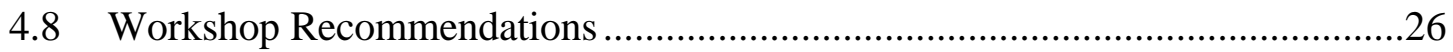

5. THE NEW RULE-BASED GASOHOL CONSUMPTION

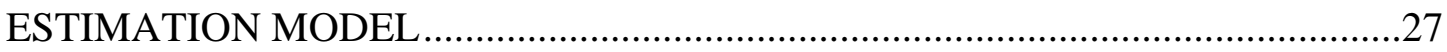

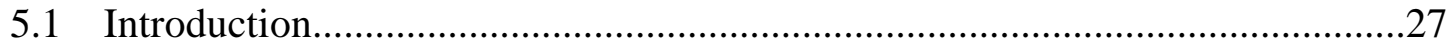

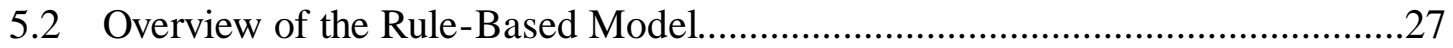

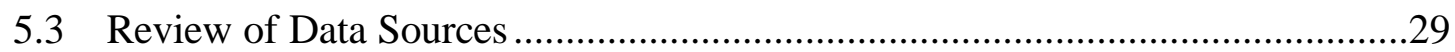

5.3.1 State-reported Fuel Usage …………………….................................29

5.3.2 IRS Quarterly HTF Revenue Data and Tax Rates ................................29

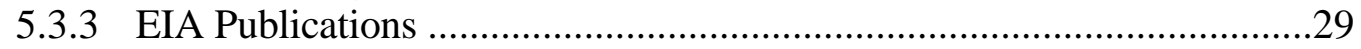

5.3.4 EPA RFG Survey Data …………………….....................................

5.3.5 EPA State Winter Oxygenate Fuel Data ....................................................32

5.3.6 RFA Reports on Ethanol Production Plant Locations ...............................33

5.3.7 State Comments ..................................................................................

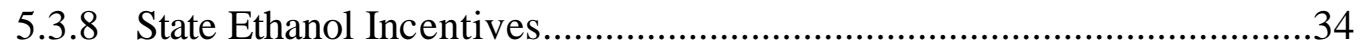

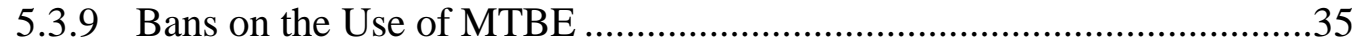

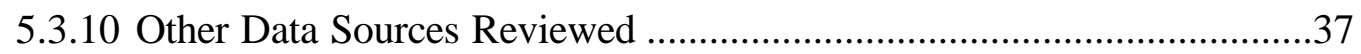

5.4 Process Description of the Rule-Based Model......................................................37

5.4.1 Computing the Control Totals …………………..................................37

5.4.2 Determining the States with Zero Gasohol Usage ...................................39

5.4.3 Determining the States with Reliable Data on Gasohol Usage .................40

5.4.3.1 RFG/Oxy Areas and Gasohol Use ............................................40

5.4.3.2 Comparison of State-reported Gallons and

EIA/EPA-based Estimates .......................................................41

5.4.3.3 Use of Gasohol in RFG/Oxy States in Areas Outside the RFG/Oxy Areas...............................................................41

5.4.3.4 Tax Incentives and/or Good Documentation.............................41

5.4.4 Determining the "Not-Accounted-For" Gallons .......................................42

5.4.5 Computing Gasohol Usage for States Not Meeting Reliability

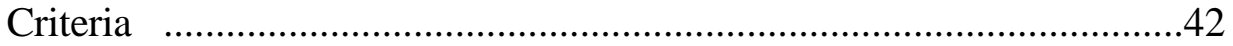

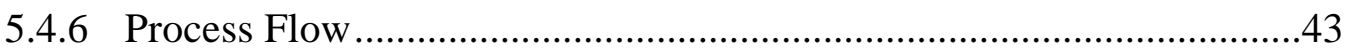

5.4.7 Considering the Impact of MTBE Bans ………………........................46

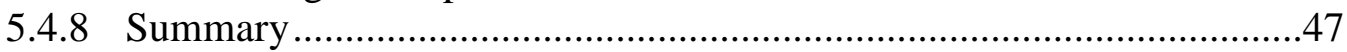

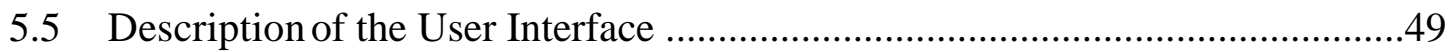

5.6 Sensitivity Analysis of the Rule-Based Model...................................................50 
6. SUMMARY AND CONCLUSIONS

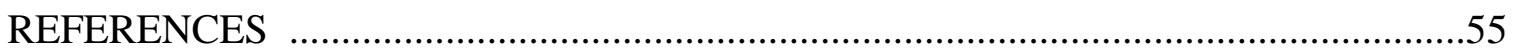

APPENDIX A: ACRONYMS AND ABBREVIATIONS ...............................................59

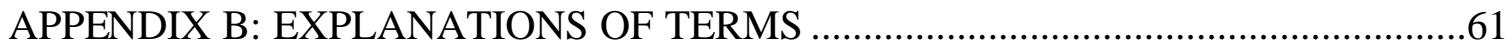

APPENDIX C: DATA SOURCES USED IN THE GASOHOL MODELS ......................63

APPENDIX D: NOTES FROM CONTACTS WITH STATE WEIGHTS AND

MEASURES PROGRAMS AND OTHER STATE INFORMATION SOURCES ....65

APPENDIX E: SENSITIVITY ANALYSIS 


\section{LIST OF TABLES AND FIGURES}

$\underline{\text { Tables }}$

1 Total Federal HTF tax revenues for CY2001 gasohol and gas used

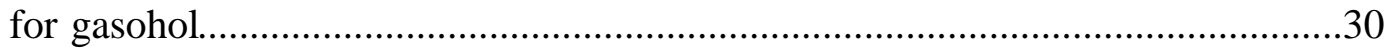

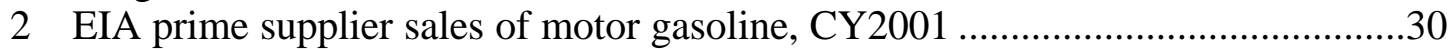

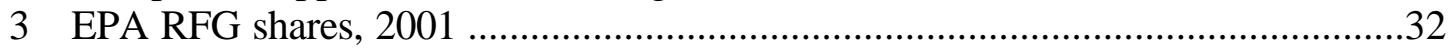

4 Winter oxygenated fuel program requirements as of October $2001 \ldots \ldots \ldots \ldots \ldots \ldots . . . . . . .33$

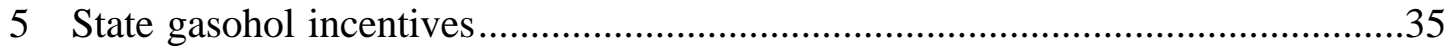

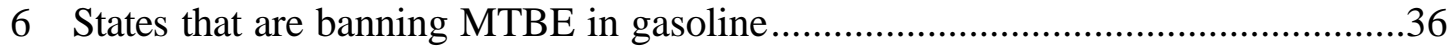

7 Federal excise tax rates during CY2001 on gasohol and gas used for gasohol .....38

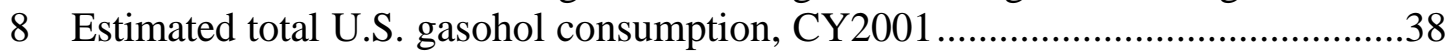

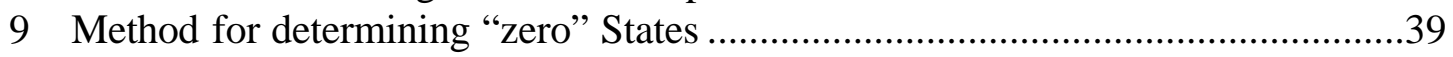

10 Estimates of gasohol consumption for analysis year 2001 ................................48

\section{Figures}

1 Overview of the regression-based gasohol consumption estimation model...........8

2 Areas within a 100-mile radius of ethanol production plants .............................19

3 Capacity of ethanol production plants in the United States ................................20

4 Overview of the new rule-based gasohol consumption estimation model ............28

5 Flow chart of rule-based gasohol estimation model, Part 1: determining zero States

6 Flow chart of rule-based gasohol estimation model, Part 2: determining States with reliable gasohol data

7 Flow chart of rule-based gasohol estimation model, Part 3: computing State shares for "not-accounted-for" States

8 Flow chart of rule-based gasohol estimation model, Part 4: additional gasohol use due to MTBE ban, estimated for the year following the analysis year 


\begin{abstract}
The Federal Highway Administration (FHWA) is responsible for estimating the portion of Federal highway funds attributable to each State. The process involves use of Statereported data (gallons) and a set of estimation models when accurate State data is unavailable. To ensure that the distribution of funds is equitable, FHWA periodically reviews the estimation models.

Estimation of the use of gasohol is difficult because of State differences in the definition of gasohol, inability of many States to separate and report gasohol usage from other fuel types, changes in fuel composition in nonattainment areas to address concerns over the use of certain fuel additives, and the lack of a valid State-level surrogate data set for gasohol use.
\end{abstract}

Under the sponsorship of FHWA, Oak Ridge National Laboratory (ORNL) reviewed the regression-based gasohol estimation model that has been in use for several years. Based on an analytical assessment of that model and an extensive review of potential data sets, ORNL developed an improved rule-based model.

The new model uses data from Internal Revenue Service, Energy Information Administration, Environmental Protection Agency, Department of Energy, ORNL, and FHWA sources. The model basically consists of three parts: (1) development of a controlled total of national gasohol usage, (2) determination of reliable State gasohol consumption data, and (3) estimation of gasohol usage for all other States.

The new model will be employed for the 2004 attribution process. FHWA is currently soliciting comments and inputs from interested parties. Relevant data, as identified, will be pursued and refinements will be made by the research team if warranted. 



\section{BACKGROUND}

The Transportation Equity Act for the $21^{\text {st }}$ Century (TEA-21) (Public Law 105-178) has increased the importance of State-level motor-fuel use data in attributing the Highway Trust Fund (HTF) receipts to highway users in each State. The underlying assumption is that Federal highway user tax payments to the HTF are received from highway users in each State in proportion to the share of highway use of motor-fuel in that State. TEA-21 established mechanisms for using motor-fuel use data as input to the apportionment of several Federalaid highway program funds. This includes the Federal Surface Transportation Program (STP) funds, Interstate Maintenance (IM) funds, and the National Highway System (NHS) funds. Highway Account contributions are also used in the computation of the Minimum Guarantee. The Minimum Guarantee ensures that each State receives at least $90.5 \%$ of its percentage contributions to the Highway Account.

The process of distributing these highway program funds to the States includes two components: (1) the Treasury Department determines the total amount of tax receipts in the HTF; and (2) the Federal Highway Administration (FHWA), U.S. Department of Transportation (DOT), estimates the portion of the total amount that is attributable to each State. Contrary to common belief, State-by-State tax contributions to the HTF are not available from the Internal Revenue Service (IRS). Because Federal motor-fuel taxes are imposed when the fuel is first removed from bulk storage and paid by the sellers, the typical Federal fuel taxpayers are oil companies. IRS tax receipts would reflect only those States in which major oil companies established their headquarters. As tax records cannot provide the desired information, FHWA must rely on other data sources to estimate the HTF contributions from highway users in each State.

\subsection{THE ATTRIBUTION PROCESS}

Under the attribution process, FHWA collects and analyzes State-reported motor-fuel consumption and tax data to develop a uniform database across all States. FHWA then determines the portion of motor-fuel that was used on highways in each State and estimates the amount of HTF contributions that are attributable to highway users in each State. To ensure equitable treatment of all States and to have a complete and reasonably consistent data set for all States, FHWA must make adjustments to the State-reported motor-fuel data. These adjustments are necessary in order to account for differences in motor-fuel taxation

procedures and reporting practices among States and to account for fuel used off-highway or by public sectors.

Thus, to ensure a fair and accurate distribution of HTF funds, the FHWA requires input from the States on fuel usage within each State. Then, through a process using State-submitted data and statistical models, FHWA attributes annual on-highway fuel usage for gasoline, gasohol, and special fuels (primarily diesel) to each State. 


\subsection{GASOHOL ISSUES}

In the case of gasohol (an alcohol blended gasoline), the reporting requirement on gasohol consumption has posed a great challenge to many States. Prior to 1993, gasohol was not defined as three blends, so only one tax rate was applied to gasohol use. When the Federal law was enacted to define three blends (i.e., alcohol content of $5.7 \%$ to less than $7.7 \%, 7.7 \%$ to less than $10 \%$, and $10 \%$ ), it also defined three different tax rates. Very few States, however, recognize the Federal definitions of gasohol. Most States consider only the 10\% blend as gasohol. In fact, only one State (Washington) currently recognizes or defines in legislation three types of gasohol. Some States define gasohol as reformulated gasoline (RFG), not as an ethanol blend. Furthermore, most States tax gasohol at the same rate as gasoline, and the tax receipts are combined for these fuel types. Consequently, States are not able to furnish data with the level of detail required by FHWA.

Since highway-funding attribution is based on Federal motor-fuel tax revenue, FHWA has to determine gasohol revenues attributed to each State using the Federal definition of the three types of gasohol. FHWA has been using a modeling approach to determine the distribution of total gasohol consumption by the three Federal gasohol tax categories by State.

As with other motor fuels, reliable estimates of gasohol consumption are important to the FHWA because this information is needed for HTF attribution purpose. Accurate gasohol consumption statistics are also required because many organizations are relying on these numbers, as published in the annual Highway Statistics, for their applications.

In recent years, the consumption of gasohol has increased rapidly. Although gasohol remains a small percentage of the total fuel used in the United States, it nevertheless has increased from $5.8 \%$ in 1991 to $10.3 \%$ in 2001 . Therefore, accurate measurement of gasohol gallons is becoming more of an issue. Furthermore, the fuel additive Methyl Tertiary Butyl Ether (MTBE) has been used as an oxygen enhancer for fuel in some States, notably California and Texas. Recently, however, some States have banned the use of MTBE because of its adverse environmental impacts on water quality ${ }^{1}$. Ethanol is also an oxygen enhancer often used in gasoline. The bans of MTBE may imply that the use of ethanol as an oxygenate will increase, which may mean that the quantity of gasohol consumed in those States will increase.

\subsection{DEVELOPMENT OF THE GASOHOL MODEL}

The gasohol consumption estimation model currently (i.e., through 2002) used by FHWA was originally developed by Battelle in 1993 and has been used by FHWA since 1994. The model uses a regression modeling approach to estimate gasohol consumption not reported by those States known to have gasohol usages. Input data for the model and the parameters for the regression equation were updated by Battelle in a subsequent study during 1999. However, the estimation methodology was not revised at that time. Current movement on

\footnotetext{
${ }^{1}$ McCarthy, James E., and Mary Tiemann, "MTBE in Gasoline: Clean Air and Drinking Water Issues," Congressional Research Service Report for Congress, 98-290 ENR, February 2000.
} 
banning the use of MTBE, the primary competitor to ethanol as an oxygen enhancer, and the upcoming re-authorization debate on the highway bill led FHWA to conclude that a significant review of the gasohol estimation procedure was necessary. Therefore, in late 2002, FHWA initiated another review of the gasohol model. 



\section{INTRODUCTION}

\subsection{PURPOSE OF THIS TASKING}

Because of the increasing importance of gasohol as a motor fuel, as well as the concern of the model being outdated, Oak Ridge National Laboratory (ORNL) was tasked by FHWA in 2002 to conduct an extensive review of the regression-based gasohol estimation model. As part of this review, ORNL participated in several motor-fuel workshops for discussing alternative data sources and possible methodologies for model improvements. Subsequently, ORNL was also tasked by FHWA to develop an improved gasohol model.

The purposes of this report are (1) to document findings from the review and analysis of the regression-based gasohol estimation model and (2) to describe the new rule-based model developed by ORNL. The review and analysis included identification of weaknesses in the regression-based modeling approach and assessments of potential new data sources. Improvements to the gasohol estimation process included the use of more reliable data sources, development of a new rule-based approach, and improvements to the user interface.

\subsection{CHALLENGES AND LIMITATIONS}

The most ideal and preferred measurement of gasohol consump tion would be accurate usage data reported from each State. As noted in Section 1.2, however, many States are unable to furnish this information to the FHWA. Although changes to State tax laws and data collection methodologies to allow for accurate gasohol reporting might be possible, they generally do not occur quickly. Changes to the gasohol estimation procedure, therefore, are needed in order to improve the accuracy of the results generated from the estimation model.

There are several difficult challenges, however. The new gasohol model needs not only to be able to produce accurate estimates for current gasohol consumption by State, it also needs to accommodate changes in gasohol consumption brought about by environmental concerns. Furthermore, the model needs to accommodate possible shifts in regional ethanol production and consumption, as well as revisions to Federal and State policies.

In making changes to the model, it is important to note that the existence of the "ideal" data set for assessing gasohol use on the State level does not exist at this time. Therefore, the limitations of each potential data set must be carefully examined to determine its accuracy, usefulness, reliability, timeliness, and availability.

\subsection{ORGANIZATION OF THE REPOR T}

The remainder of this report consists of three major chapters. Chapter 3 is a review of the regression-based gasohol estimation model currently (through 2002) being used by the 
FHWA. Discussions on major data sources and the process used in deriving the state-level consumption estimates are included in this section. An analytical assessment of the model and certain technical issues in its modeling process are also presented.

In January 2003, FHWA sponsored a Gasohol Improvement Workshop and invited a panel of experts (mostly from Federal agencies interested in gasohol) to help identify emerging issues that might impact estimates of future gasohol consumption and to initiate discussions on these issues. Significant inputs were gathered during, and following, the workshop from many of the panelists. A summary of the workshop discussions is presented in Chapter 4 of this report. This workshop provided crucial guidance to the development of a new gasohol model.

Chapter 5 provides a description and technical discussion of the new, rule-based gasohol model. It provides a review of potential data sources that were examined. A process description and analytical discussion of the rule-based model are also provided in this section of the report.

A summary of findings and conclusions based on the tasking are provided in Chapter 6 . Appendices contain a list of acronyms and abbreviations and an explanation of terms used in this report, as well as additional supporting materials. 


\section{THE FHWA REGRESSION-BASED GASOHOL ESTIMATION MODEL}

This chapter provides an extensive review of the regression-based model (Section 3.1) that is currently (i.e., through 2002) being used by FHWA to estimate gasohol consumption among the States. The analytical assessment described in Section 3.2 identifies specific areas of the model that need corrections or improvements.

\subsection{DESCRIPTION OF THE REGRESSION-BASED MODEL}

\subsubsection{Background}

The regression-based gasohol consumption estimation model was originally developed by Battelle under a contract with FHWA during 1993-1994. The original model was reviewed and updated by Battelle for FHWA in 1999. During the 1999 review, Battelle validated and verified the input data to the model and evaluated the goodness of the regression equation. Specifically, it evaluated how the equation performed in determining gasohol usage for the States in that year.

As a result of the 1999 review, the gasohol estimation model was revised. The screen design of the model (i.e., user-interface) was also updated to improve the ease of transition between data tables maintained by FHWA. The assessment of State data on gasohol, the analysis of the regression equation, and the conclusions drawn from this effort were documented in the 1999 Battelle report, Gasohol Estimation Model Review. ${ }^{2}$ Battelle noted that the revised model more accurately reflected new data identified during the 1999 study.

\subsubsection{Overview}

Major data sources used in the regression-based gasohol estimation model are Form FHWA551M and IRS quarterly Federal tax revenue data. Information collected by contacting States through a questionnaire survey conducted as a part of the 1999 model review activity was also used. State responses to this survey were documented and provided in Gasohol Estimation Model Review, State Responses to Questionnaire ${ }^{3}$ by Battelle. A description of all data sources used in this model is provided in Section 3.1.3.

The regression-based gasohol consumption estimation model consists of two spreadsheet files. These files were originally developed in Lotus- 123 format and were converted into Microsoft Excel recently by FHWA. The files are identified as ESTNEWXX.XLS and IRSXX.XLS, where XX denotes the analysis year. For example, files used for analysis year 2000 are named ESTNEW00.XLS and IRS00.XLS. ESTNEWXX.XLS is the main analysis

\footnotetext{
${ }^{2}$ Battelle, Gasohol Estimation Model Review, report submitted to Federal Highway Administration, April 30, 1999.

${ }^{3}$ Battelle, Gasohol Estimation Model Review, State Responses to Questionnaire, report submitted to Federal Highway Administration, April 30, 1999.
} 
module for the gasohol estimation model, while IRSXX.XLS contains the IRS control total, which is used to calibrate the model. Figure 1 presents a flow chart of processes contained within the regression-based gasohol estimation model. Detailed descriptions of these processes will be presented following the discussion of major data sources.

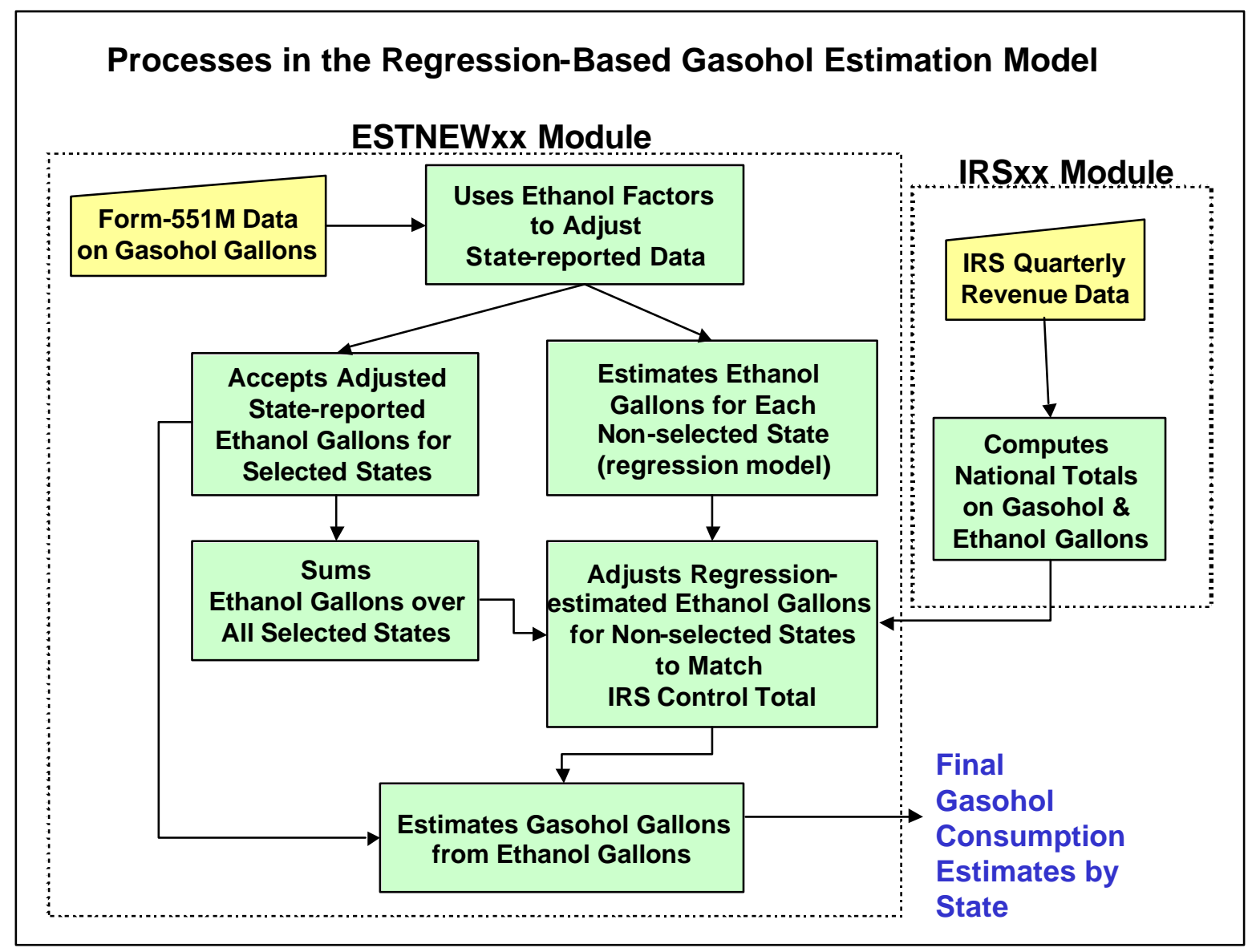

Figure 1. Overview of the regression-based gasohol consumption estimation model.

\subsubsection{Data Sources}

The following data sources provide input to the regression-based gasohol consumption estimation model. A brief description on their uses in the model is also provided. Additional discussion on the use of these data is included in Section 3.2.

\subsubsection{State-submitted Motor Fuel Data}

Form FHWA-551M ("Monthly Motor-Fuel Consumption") is completed by the State agency that collects the motor fuel tax. The form is submitted to FHWA no later than 90 days after the close of the month for which data are being reported. Unavailable data from one month can be included in the next month's report, with notes of explanation included on the second page of the form. The State enters the total number of gallons of gasohol based on several 
State taxation characteristics (e.g., gross volume reported, fully tax exempt gallons, gross volume taxed, fully refunded gallons, and net volume taxed).

Once a year, States also submit Form FHWA-556 ("State Motor-Fuel Tax Receipts and Initial Distribution by Collection Agencies") to report their annual motor-fuel tax revenue data. Input from this form is used by FHWA as a cross-check to ensure that total calendar year gallons match the sum of the monthly gallons reported for the State during that year.

\subsubsection{IRS Quarterly Tax Revenue Data and Tax Rates}

IRS taxes gasoline, gasohol (gasoline blended with specific volume percent of ethanol), and gasoline to be blended with ethanol (within a 24-hour period) as separate motor fuel products. These products are taxed under different tax rates. The three blends of gasohol $(10 \%$, less than $10 \%$ to $7.7 \%$, and less than $7.7 \%$ to $5.7 \%$ ) are also taxed differently. Refunds and credits provided by IRS for gasohol and gasoline to be used in gasohol are not separated by the three different gasohol blends, however.

Federal motor fuel excise taxes, including gasohol, are reported using IRS Form-720 (“Quarterly Federal Excise Tax Return”). The spreadsheet IRSXX of the regression-based gasohol model contains tax revenue data provided by U.S. Treasury based on information collected from IRS-Form 720 and other related tax forms. As noted earlier, IRS data are available only at the national level not at State level. Total quarterly tax liabilities (dollars) on gas-for-gasohol and gasohol-sold, for each of the three types of gasohol, are entered annually by FHWA analysts into the worksheets in IRSXX. Tax rates in these worksheets are updated periodically when rate changes occurr. Tax rates on all types of motor fuels are available from Table FE-121 in Highway Statistics as well as from IRS tax forms.

Based on IRS tax revenue and tax rates, the model computes total gasohol gallons for a fiscal year. Note that IRS fuel taxes include some funds that are not deposited into the HTF. These include percentages for the Leaking Underground Storage Tanks (LUST) trust fund and the general fund. These rates have varied through the years. Generally the LUST rate has been about 0.1 cents/gallon, but the rate for deficit reduction (general fund) has ranged from 2.5 to 6.9 cents/gallon on gasohol.

\subsubsection{Environmental Protection Agency Nonattainment Areas Information}

A nonattainment area is defined as a locality where the air pollution levels persistently exceed the ambient air standards of the Clean Air Act (CAA) Amendments of 1990. Air pollutants covered by the standards include ozone, carbon monoxide $(\mathrm{CO})$, nitrogen dioxide, sulfur dioxide, particulate matter, and lead. ${ }^{4}$ The U.S. Environmental Protection Agency (EPA) maintains a list of nonattainment areas. ${ }^{5}$

The CAA Amendments of 1990 address automobile emissions in an effort to decrease levels of ozone and CO. Two primary additives - MTBE and ethanol - have been used to increase the level of oxygen in motor fuels. (As noted in Section 1.2, MTBE is being phased out in

\footnotetext{
${ }^{4}$ Environmental Protection Agency, "Green Book," http://www.epa.gov/oar/oaqps/greenbk/.

${ }^{5}$ Environmental Protection Agency, "USA Air Quality Nonattainment Areas," http://www.epa.gov/airs/nonattn.html .
} 
some States as an oxygenate because of issues concerning water pollution.) Oxygenated fuels comprise about $35 \%$ of the nation's gasoline. ${ }^{6}$ Two clean fuels programs are the Winter Oxygenated Fuels Program, which targets $\mathrm{CO}$ pollution in nonattainment areas, and the RFG Program, which targets urban areas with ozone (smog) pollution. The Energy Information Agency (EIA) estimates that, in recent years, RFG makes up about $30 \%$ of the nation's total gasoline.

To capture the relationship between ethanol usage and the environmental requirement of the State, data on the percentage of ethanol market share in carbon monoxide nonattainment areas and the percentage of travel within an oxyfuel area in relation to the total travel within the State are obtained from the EPA. These percentages are multiplied together to derive a "carbon monoxide factor" which is then used in the regression-based gasohol model.

\subsubsection{Renewable Fuels Association Reports}

Proximity to an ethanol production plant is included as a factor in the regression-based gasohol estimation model. This information is based on ethanol production capacity published by the Renewable Fuels Association (RFA). ${ }^{7}$ In some instances, only a combined production capacity figure is published for a company with plants in multiple States. In this situation, an estimated production capacity for each of the States involved is calculated by equally dividing the combined total among all States.

The RFA publication also includes information on State excise tax exemptions and producer credits given to encourage the use of ethanol by the States. This information was used in conjunction with similar information published in The Clean Fuels Report by J. E. Sinor Consultants (see Section 3.1.3.6) to provide inputs to two of the variables in the regressionbased gasohol model.

\subsubsection{State Responses to Gasohol Questionnaire}

During its 1998 gasohol model reviewing process, Battelle conducted a survey for FHWA concerning State gasohol data. According to that survey, only about 23 States report reasonably good gasohol data, another 10 States do not use gasohol, and the remaining 18 States have unreliable data - they either do not report gasohol use when it is known to exist or they report an estimated number with a questionable accuracy. ${ }^{8}$

In that survey, Battelle interviewed every State to obtain information on data collection methods used by each State, the State's opinion on the reliability of its gasohol data, existing State incentives, gasohol blending levels and their market shares in the State, and the State's ability to separate gasohol from gasoline reporting. Furthermore, information on the source of the estimate for the gasohol usage (e.g., Department of Revenue, Department of Safety, motor fuel distributors, etc.) was also collected.

\footnotetext{
${ }^{6}$ Renewable Fuels Association, Ethanol Industry Outlook 2001: Clean Air, Clean Water, Clean Fuel, http://www.ethanolrfa.org/rfareport2001.html?NS-search-set=13e6d0\s65.6d004d\&NS-doc-offset=0\&.

${ }^{7}$ Renewable Fuels Association, "Ethanol Production Facilities," http://www.ethanolrfa.org/eth prod fac.html .

${ }^{8}$ Federal Highway Administration, “The Buck Starts Here, Motor Fuel Attribution: FHWA Estimation of Highway Trust Fund Tax Receipts from Each State,” presentation for Gasohol Workshop, February 2003.
} 


\subsubsection{The Clean Fuels Report}

The Clean Fuels Report prepared by J. E. Sinor Consultants provided information on State ethanol incentives - specifically, tax exemptions on blended fuel and producer incentives. According to this February 1998 report, nine States allowed some type of State tax exemption on blended fuel and twelve States provided producer incentives to encourage ethanol usage. ${ }^{9}$

\subsubsection{Description of the Regression-based Gasohol Estimation Process}

As mentioned previously, estimating gasohol consumption by State for the HTF attribution purpose is a challenging task. Since 1993, gasohol has been taxed at three different blending levels by the IRS, each with a different tax rate. However, very few States can distinguish among the Federal definition of three different blends of gasohol. Most States consider only the $10 \%$ blend as gasohol. Thus, the gasohol usage reported by States must be adjusted by FHWA to account for each blend.

The current (i.e., through 2002) FHWA gasohol attribution practice follows these steps: States providing reasonably good gasohol data (gallons) are allocated their share; States known to have no gasohol consumption are allocated zero; shares for the remaining States are allocated using gasohol consumption estimated from the regression model. This regression-based gasohol model was originally developed and used for the first time in the 1994 edition of Highway Statistics. Before that, only State-reported gasohol gallons were used, and no estimation was made by FHWA for non-reporting States. Thus, some States may have had zero usage recorded in editions of Highway Statistics prior to 1994 even when gasohol was used in the State.

In the following paragraphs, the 2000 analysis-year is used as an example to briefly describe the processes used in the regression-based model. In-depth analytical assessment of the methodologies is discussed later in Section 3.2.

\subsubsection{Computing the Control Total}

The IRS00 spreadsheet module contains Federal tax revenue data provided by the Treasury, based on information collected from IRS-Form 720, for the four quarters in tax-year 2000. The data includes quarterly tax liabilities (dollars) on gasoline-for-gasohol and gasohol-sold, for each of the three types of gasohol. The FHWA analyst is responsible for entering these revenue data into worksheets in IRS00. FHWA also enters Federal tax rates, for each of the revenue types, using information obtained from Table FE-21B of the Highway Statistics. The total gasohol used (in gallons) is then automatically computed for each blend of gasohol using a simple formula, dividing the tax liability by its corresponding tax rate. Note that IRS data do not separate refunds and credits by the three blends of gasohol. The shares of refunded or credited tax liability among these three types of gasohol, therefore, are assumed to be the same as the shares calculated from those quarterly reported total tax liabilities.

\footnotetext{
${ }^{9}$ Battelle, Gasohol Estimation Model Review, report submitted to Federal Highway Administration, April 30, 1999, Table 5.
} 
After adjusting amounts associated with refunds and credits, total gallons of ethanol used in gasohol are calculated for each quarter. These quarterly totals are consolidated into an annual national total and used as a control total to calibrate the estimates obtained from the regression equation within the ESTNEW00 module.

\subsubsection{Use of State-Provided Data}

FHWA receives the amount of gasohol consumption (in gallons) from States as reported on the Form FHWA-551M. These data are entered into a worksheet in the ESTNEW00 module as an input to the estimation model. These State-reported gasohol consumption estimates are multiplied by an ethanol adjustment factor to calculate the gallons of ethanol that are used by each State. In general, the ethanol adjustment factor used for most States is $10 \%$ (i.e., a $10 \%$ blend). Different adjustments are made to acknowledge under-reporting in some States (as identified during interviews conducted under the 1999 model review effort). Adjustments are also made for States that use more than one blending for gasohol. Finally, for States that are not using gasohol, this factor is set to 0 .

FHWA then assesses the accuracy of State-reported consumption to select those States that represent accurate reporting of the gasohol used. Thirty-three States meet the FHWA selection criteria (including States that do not use gasohol). For these selected States, FHWA accepts the State-provided and FHWA-adjusted ethanol gallons as accurate. No further estimation process is required for these States.

\subsubsection{Estimating Ethanol Gallons for Non-selected States}

The ethanol consumption for States that are not selected by FHWA (i.e., States whose reported values are in question or States that do not report any gallons but are known to use gasohol) are estimated using a regression equation. This regression equation was originally developed by Battelle in 1994 and revised in 1999. The equation is further discussed in Section 3.2.2 of this report.

Since ethanol consumption for the nation (obtained from IRS00) and the selected States are known, the total ethanol consumption from those non-selected States can be calculated by simple subtraction. The resulting difference is then used as a control total to adjust the ethanol consumption estimates produced from the regression equation for those non-selected States. More specifically, State-level ethanol consumption estimates produced by the regression equation are added to form a total for these non-selected States. Regressionestimated consumption for each non-selected State is then divided by this total (i.e., sum of all regression-based estimates) to produce a "share" (i.e., percentage of the total) for the State. The control total (i.e., the difference obtained from above) is then distributed to individual States according to these calculated shares. The values generated from this process are the amount of ethanol consumption estimated for each of the non-selected States. All these computations are performed within the ESTNEW00 module.

\subsubsection{Estimating Gasohol Gallons}

The annual ethanol consumption by State, either from State-provided data or by regressionestimation, is adjusted one more time to determine the total gasohol consumed by each State. This adjustment is done by taking a State's ethanol consumption and dividing the number by 
its percentage blends of gasohol (i.e., at 5.7\%, 7.7\%, or 10\%). Although the percentage blend for each State is provided on FHWA-551M, many States do not report their percentage blend. Information collected from the 1999 Battelle survey is therefore used in the ESTNEW00 module for these States.

\subsubsection{The Regression Estimation Method}

The core of this gasohol model is a statistical regression equation developed by Battelle in the 1994 study and recalibrated in the 1999 review. This equation and its parameters were built as a separate worksheet within the ESTNEWXX module. Each year, FHWA performs the necessary updates on State sales and other input data elements in this module with the latest information available. The system then proceeds to re-calculate the gasohol consumption estimates for each State.

The regression equation was derived based on relationships between gallons of ethanol consumed by a State and several other explanatory variables (also referred to as predictors in this report). These explanatory variables include the proximity of an ethanol plant to the subject State, the amount of the ethanol producer's incentive in the State, the amount of the blender's incentive in the State, the total amount of gasoline used in the State, and a CO factor.

The proximity of an ethanol plant to the State is a factor that reflects ethanol production capacity in the State. Ethanol incentives provided by the State are used to encourage the use of ethanolbased fuels and, therefore, can affect the sales of the ethanol product. Not surprisingly, ethanol usage in a State is highly correlated with the total amount of gasoline used in that State, combining both non-blended gasoline and gasohol blends. Therefore, this variable (i.e., total gasoline usage) is also included as an explanatory variable to the regression model. Besides the obvious associations between gasoline and ethanol consumption, a major advantage of using this information is that this data is readily available from State-submitted Form FHWA-551M.

The $\mathrm{CO}$ factor used in the regression analysis was calculated based on the market share of ethanol and adjusted by the percentage of vehicle- miles traveled (VMT) within the ethanol fuel area. Specially, Battelle used data produced by EPA on the percentage of ethanol market share in CO nonattainment areas to calculate weighted average market shares for States. These State market shares were then multiplied by their associated VMT adjustment factor for each State. These VMT adjustment factors are computed as the percentage of travel within an oxyfuel area in relation to total travel occurring within the State.

\subsection{ANALYTICAL ASSESSMENT OF THE REGRESSION-BASED MODEL}

In an effort to improve the accuracy of gasohol consumption estimates produced by FHWA for its annual attribution process, FHWA tasked ORNL to conduct a critical review of the regression-based gasohol model. This in-depth review and assessment of the model was necessary in order for ORNL to (1) fully understand the assumptions and methodology employed within the model; (2) identify possible shortfalls in the model; and (3) recommend 
improvements or alternatives to the model. As indicated in Section 3.1, the regression-based gasohol consumption estimation model consists of two Excel spreadsheet files - IRSXX and ESTNEWXX. Processes within these two spreadsheet modules were addressed in Section 3.1. Discussions presented in the following section focus on technical issues found during the in-depth assessment.

\subsubsection{The Spreadsheet Files}

\subsubsection{IRSXX File}

This spreadsheet consists of five worksheets, one for each of the quarterly HTF revenue statistics and one for the annual total. The purpose of this file is to use data from IRS on Federal gasohol tax revenues, with associated tax rates, to estimate the total gallons of gasohol used in the U.S. for each of the three gasohol blends. This conversion (i.e., from dollars to gallons) is based on a simple formula of dividing the tax liability (dollars) by its corresponding tax rate (dollars per gallon). All gallon estimation processes are performed within the quarterly sheets. The annual worksheet contains totals summed over the four quarterly sheets.

Total gallons of ethanol needed for blending into gasoline to produce gasohol are also estimated from the process described above in each of the quarterly worksheets. These quarterly totals (both gasohol and ethanol gallons) are then consolidated into annual national totals contained in the annual worksheet. The national ethanol total is used (with autolinkage between spreadsheet files) to calibrate the State estimates obtained from the regression equation within the ESTNEWXX module.

A comprehensive review of this spreadsheet module, conducted by ORNL, identified several technical errors and concerns. These computational issues are discussed below.

- Although gasohol tax receipts provided by IRS (Treasury) are separated into three blending levels, refunds and credits are not. Because of a lack of other available information, shares of refunds and credits for the three blends are, therefore, assumed to be the same as the gasohol receipts collected in the same quarter. While this assumption is reasonable, the formula used in performing this separation contains errors. There is a mathematical error in all quarterly spreadsheets except for the first quarter. When copying formulas from the first quarter spreadsheet to other quarters, the model designer failed to correct the formulas to reflect appropriate reference locations in the spreadsheet cells. Instead of referring to cells in the current worksheet (e.g., quarter 2) during the computation of totals, the formula continues to use the totals computed from the first-quarter worksheet. Impact from this error is generally small because the amount of refunds and credits is typically much lower than the tax collected.

- The tax rates used to convert revenues into gallons are inaccurate. The user of the gasohol model is required to manually enter updated tax rates into the appropriate spreadsheet cells whe never new changes occur. Since the model was first developed in 1993, there have been several changes made in the Federal motor fuel tax rates. 
These rates, however, have not been properly updated for tax years after 1994. Impacts due to this error vary from year to year, depending on the size of the tax rate changes.

- During the calculation of total gasohol gallons and total ethanol gallons needed for blending into gasoline, refunds and credits are added into, rather than subtracted from, the overall consumption. The resulting gallons, therefore, are slightly higher than what they should be. Because the size of refunds and credits are typically small, the impact on the estimated U.S. control total is relatively small.

- The Federal motor fuel tax rate contains a portion that goes into non-HTF accounts. For example in tax year 2001, a 0.1 cent per gallon tax from gasohol goes to LUST while 2.5 cents per gallon goes into the general fund. The amount of quarterly tax revenues provided to FHWA by Treasury, in fact, contains only receipts certified by IRS for the HTF accounts (Highway account and Mass transit account). Therefore, the conversion from dollars to gallons should use HTF portion of the tax rates instead of the fuel tax rates as posted by the IRS. For instance, instead of 13.1 cents per gallon tax for the $10 \%$-blend gasohol, the HTF portion of the revenue is 10.5 cents per gallon. Because the denominator in the conversion formula is larger than what it should be, the resulting gallons are smaller. Therefore, the control total as estimated in the IRSXX module of the gasohol model is significantly understated.

Consequently, gasohol consumption for States that were estimated from the regression-based model are underestimated. This, undoubtedly, is the most significant problem found in the current regression-based model. It impacts gasohol share estimates for all States.

\subsubsection{ESTNEWXX File}

The main estimation process of the gasohol model is included in the ESTNEWXX spreadsheet file. This module contains seven worksheets as well as a title sheet. Simple instructions, along with a cell for FHWA to input the target year for analysis, are given in this title sheet. State-reported gasohol gallons and gasoline consumptions, from FHWA$551 \mathrm{M}$ or MF-20, are entered in an input worksheet, entitled "State."

There is some amount of subjectivity concerning the determination of which States submit "good" gasohol data. The initial decision was based on the information collected by Battelle from its 1999 survey of States. When a State determines its usage based on either State tax returns or from distributor reports, the State data is considered valid. It should be noted that the State data may be considered "good" when the State actually reports and has zero gasohol usage. Based on the results of the 1999 survey, the model currently (i.e., through 2002) accepts 33 States as having "good" data. Of the remaining States (including the District of Columbia), 13 States reported zero usage when they were expected to have some gasohol consumption, and five States reported unreliable number of gallons. For these 18 States, the model is used to estimate their gasohol usages. 


\subsubsection{The Regression Equation}

The core of the ESTNEWXX module is a statistical regression equation that produces estimates for ethanol consumptions at the State level. The regression equation currently implemented in the model consists of seven terms. The mathematical form of this equation is as follows:

$$
\begin{aligned}
& \text { EthanolConsumption }=-3691515+7887941 * \text { PLTPROX }-195554 * \text { PRIN *PLTPROX } \\
& -3939 * \text { PRIN *CO+963*BLIN *CO+968*BLIN *CO* PLTPROX } \\
& +424083 * \text { BLIN * PLTPROX }+0.00215 * \text { TOTGAS }
\end{aligned}
$$

where

EthanolConsumption is the estimated number of ethanol gallons consumed by a State,

PLTPROX is the proximity score of a State to an ethanol plant with values ranging from 0 to 6 ,

PRIN is the amount of the producer's incentive in the State in dollars per thousand gallons,

$B L I N$ is the amount of the blender's incentive in the State in dollars per thousand gallons,

$\mathrm{CO}$ is the product of two percentages, the ethanol market share and the VMT in the nonattainment areas within the State, and

TOTGAS is the total amount of gasoline use reported by the State.

This regression equation was set up as a formula within a worksheet to calculate ethanol gallons used in gasohol blends by State. Regression parameters (i.e., coefficients of the variables in the equation) and their associated variances were included in a separate worksheet from all other data. This allows modifications of these parameters to be performed without the need to change formulas embedded in the data cells. The following section provides an explanation on all variables used in this regression equation.

\subsubsection{Inputs to the Regression Equation}

\subsubsection{State-level Ethanol Consumption}

As discussed in Section 3.1.4.2, State-reported sales on gasohol and gasoline were obtained from the MF-20 tables maintained by the FHWA for its annual attribution process. The State-reported gasohol consumption (i.e., sales) data were converted into ethanol consumption for each State using adjustment factors. These adjustment factors were generated based on the State's responses to the 1999 Battelle survey. For States that use only $10 \%$ blend gasohol, this factor is 10 . If a State does not use gasohol, the adjustment factor would be set to zero. When multiple gasohol blends are used in a State, its adjustment factor would be a market-shares-weighted sum. For example, if $80 \%$ of a State's gasohol market is on the $10 \%$-blend and $20 \%$ is on the $7.7 \%$-blend, the adjustment factor would be calculated as $0.8 * 10+0.2 * 7.7$, which is 9.54 for the given State. 
These State-level ethanol consumption values, as obtained from above, are then used as the input for the response (i.e., dependent variable) in the regression model. The remaining discussions are on inputs to the predictors (i.e., independent variables) of the regression equation.

\subsubsection{Proximity to a Production Plant}

The PLTPROX variable is defined by applying a simple additive scoring method to each State. The scoring method takes into consideration the ethanol production capacity of the State and its likelihood of using gasohol (i.e., being adjacent to a production State). The assumption is that if ethanol is produced in or near a State, it will be more likely for the State to use ethanol-blended fuel. Data on ethanol production capacity are available from the RFA, and adjacent States are determined using a U.S. map. The proximity score (i.e., PLTPROX) ranged from 0 to 6 , with 6 being the most likely to use ethanol in the State. A State gets one point from each of the following criteria if the condition is met:

- has ethanol production capacity,

- has ethanol production capacity over 30 million gallons per year,

- has ethanol production capacity over 100 million gallons per year,

- is adjacent to a State with production capacity,

- is adjacent to a State with production capacity over 30 million gallons per year,

- is adjacent to a State with production capacity over 100 million gallons per year.

\subsubsection{Incentives}

Two incentives are used in the model, the producer's incentive (i.e., PRIN) and the blender's tax incentive (i.e., BLIN). The producer's incentive is calculated based on gallons of ethanol produced while the blender's tax credit is based on gallons of ethanol blended with gasoline. Ethanol incentives are provided by the Federal government and by some States to encourage the use of ethanol-based fuels. Data on incentives can be obtained from the RFA and The Clean Fuels Report. The most important incentives are a partial exemption to the Federal motor fuel excise tax for gasohol (at three levels) and an income tax credit for ethanol used as a motor fuel. Currently, the Federal ethanol tax incentive is nominally worth up to 53 cents per gallon of ethanol.

\subsubsection{Carbon Monoxide Factor}

Because ethanol is commonly used as an oxygen enhancer to fulfill requirements from environmental regulation and policies, a positive correlation between ethanol usage and the characteristics of non-attainment areas in States is expected. In order to capture these impacts, the model includes a $\mathrm{CO}$ factor in its regression equation. This factor is defined as the product of two percentages, the weighted ethanol market share in CO non-attainment areas in the State and the VMT share in these oxyfuel areas for the State. Estimates for these two shares were obtained from EPA.

\subsubsection{Total Gasoline Used by State}

Gasoline consumptions reported by a State on its monthly FHWA-551M are summarized into an annual total by FHWA and published in the Highway Statistics. Since gasohol is an ethanol-blended gasoline, the amounts of gasoline and gasohol consumed within individual 
States are expected to be highly correlated. Therefore the total gasoline consumption by State, TOTGAS, is also included in the model as a predictor.

\subsubsection{Review Comments on the Regression Equation}

The predictors used in the regression-based gasohol consumption estimation model are all excellent choices of factors that could have impacts on ethanol consumption. Concerns raised in this section are mainly focused on how these predictors were used together in the equation (i.e., the model formulation).

\subsubsection{Proximity to a Production Plant}

Because gasoline and ethanol blends (i.e., gasohol) can easily separate into phases with low levels of water contamination, special attention needs to be taken to shield it from possible water incursion. As a result, most gasoline/ethanol blending is done at distribution terminals located near retail distribution points. The ethanol used for blending is usually shipped by rail or truck to avoid moisture, which typically exists in pipelines. This method of shipping introduces additional logistics and handling costs to the use of gasohol fuel. Consequently, transportation cost is viewed as a factor that might impact gasohol demands.

Unfortunately, data on transportation costs for ethanol used in gasoline blending is not readily available. The "proximity to a production plant" is, therefore, a reasonable surrogate for the model to capture this relationship. The importance of this predictor, however, was overly emphasized in the regression model. As seen from the regression equation (see Section 3.2.2), PLTPROX appears in four out of the seven terms (excluding the constant term). Consequently, the model is expected to be sensitive to any slight changes in the value of this variable.

The proximity score, as defined in the regression-based model (see Section 3.2.3.2), takes into account both the size of ethanol plants (i.e., capacity) and their locations (adjacent State). The rational is that a State would be more likely to use gasohol if it is adjacent to other States that produce ethanol. This is a valid and rather straightforward assumption. The drawback is that being adjacent to a State does not necessary mean that it is close enough (distance-wise) to get transportation benefit from ethanol plant(s) located in that State. For example, as shown in Figure 2, shipping products from the Tennessee plant to South Carolina is much closer than shipping to Mississippi even though Mississippi is an adjacent State to Tennessee. To better reflect the transportation cost, it is suggested that areas within a specified distance surrounding the ethanol plants (e.g., within 100 miles radius of the plant), instead of "adjacent to a State," should be considered. 


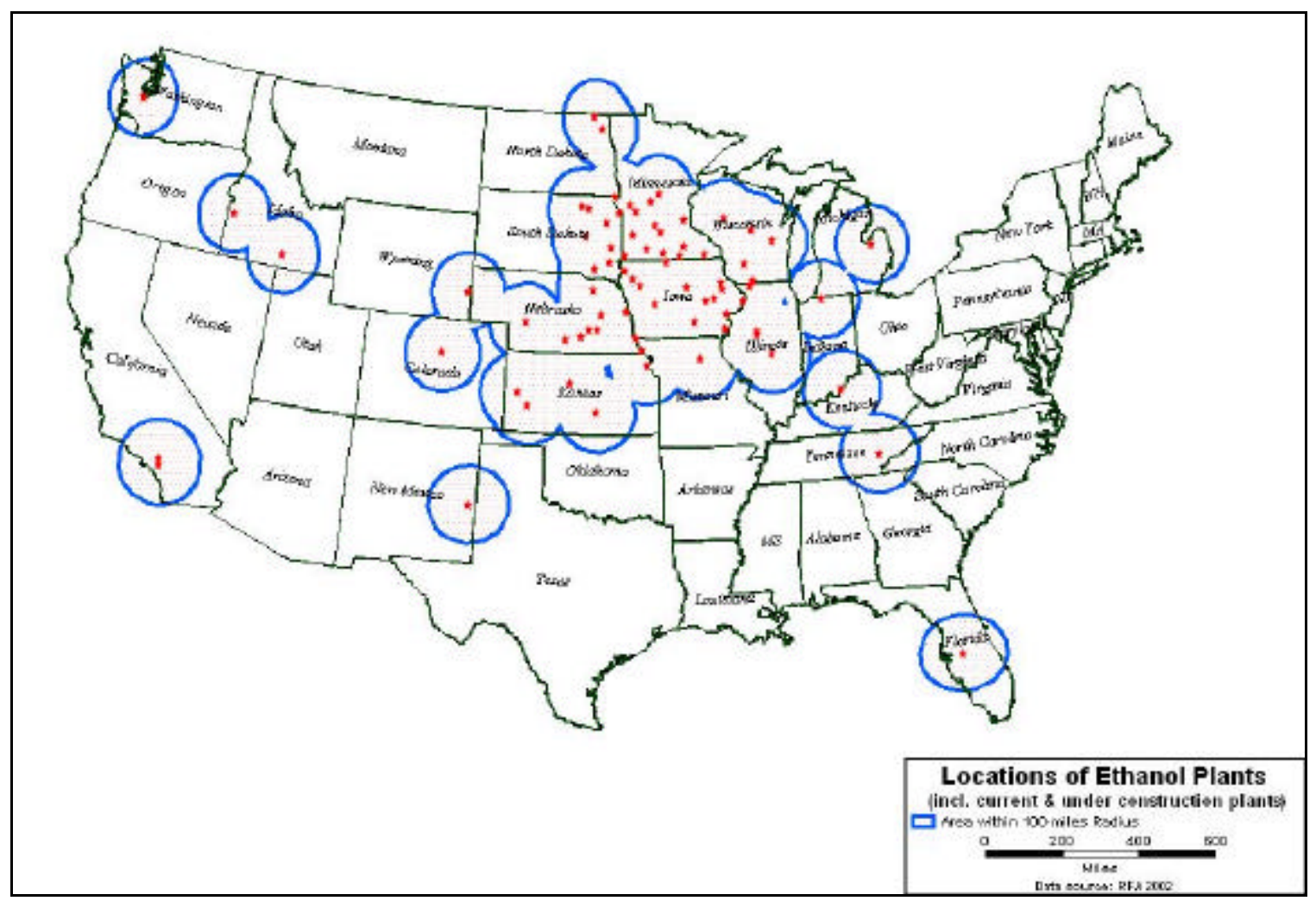

Figure 2. Areas within a 100-mile radius of ethanol production plants. Source:

Renewable Fuels Association, "Ethanol Production Facilities," 2002. Note: These data are updated by RFA every six months.

Note that capacity was not incorporated in the example shown in Figure 2, as this figure only illustrates locations of the plants with respect to their neighboring States. The size of a production plant unquestionably impacts the size of its market area. Figure 3 displays current production capacities at ethanol plants in the lower 48 States as of November 2002. The size of plants varies significantly, ranging from below 1 million gallons per year to approximately 200 million gallons annual production capacity. Certain combinations of the size and distance (similar to those implemented in the current model) might be necessary when modeling ethanol consumption by State. Note that production "capacity" does not necessarily reflect actual production, however. Furthermore, not all ethanol is produced for gasohol blending purposes. This is a data limitation and should be kept in mind when applying this information for gasohol consumption estimation. 


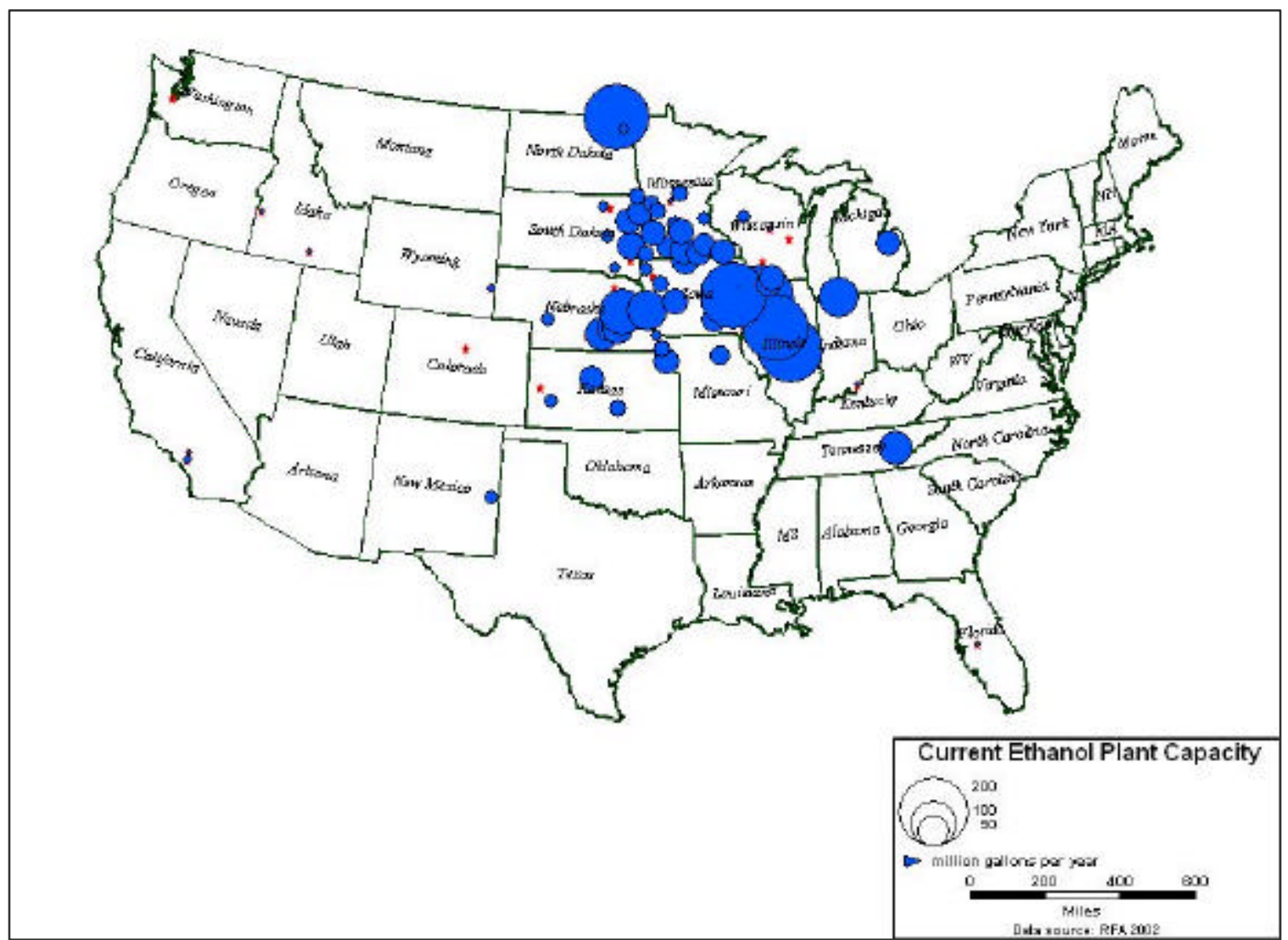

Figure 3. Capacity of ethanol production plants in the United States. Source: Renewable Fuels Association, "Ethanol Production Facilities," 2002. Note: These data are updated by RFA every six months.

\subsubsection{Incentives}

It has been pointed out that the nominal tax incentive value generally quoted (i.e., 53 cents per gallon of ethanol) overstates the actual ethanol subsidy. ${ }^{10}$ The major reason is that motor fuel taxes are assessed by volume (i.e., gallons) and ethanol has only about two-thirds of the energy content of gasoline for an equal volume. For the same miles driven, more ethanol is used by volume and, therefore, greater tax receipts are collected. Moreover, although incentives affect ethanol production, whether they impact the amount of gasohol sold is still not apparent because ethanol can be blended in various forms besides gasohol. Further investigation in this area is still necessary.

\subsubsection{Model Formulation}

The regression-based model used data from approximately two-thirds of the States (including those not using gasohol as motor fuels) to estimate missing ethanol consumption values for the remaining one-third of the States. That is, approximately 33 observations were used in developing an eight-term regression equation (including the constant term). Although this regression equation might have had a reasonable $\mathrm{R}$-square value for the data set used in

\footnotetext{
${ }^{10}$ Andress, David, Ethanol Tax Incentives and Issues, a report prepared by David Andress \& Associates, Inc., under contract with Oak Ridge National Laboratory, April 1998.
} 
building the model, performance of this regression model is not likely be sustainable when new data sets are applied to the same equation. Because the equation has been overly adjusted to fit one particular data set, it lacks robustness.

The generalization of applying a regression equation built on data obtained from 33 specific States to the other 18 States also raised some concerns. This assumes that all characteristics in those to-be-estimated States (18) are basically the same as those used for the regression equation development (33 States). This is a rather weak assumption, if not problematic.

Furthermore, the current formulation of the model (i.e., regression equation) allows a negative value of ethanol consumption to be produced. Although a large portion (about 30\%) of the State ethanol consumption is zero because those States are not using gasohol as a motor fuel, all other consumption values should be greater than zero. Currently, the regression equation can generate negative estimates for States that indeed are using gasohol as motor fuels. If the regression approach were to be retained for future gasohol estimation model, a certain constraint to restrain the response (i.e., ethanol consumption) to nonnegative values would need to be implemented so that this situation could be prevented. 



\section{GASOHOL MODEL IMPROVEMENT WORKSHOP}

In an effort to improve the accuracy of the current gasohol consumption estimates and to respond to potential impacts from the incoming regulatory policy changes on MTBE, FHWA invited a group of experts to attend a one-day "Gasohol Model Improvement Workshop." This workshop, sponsored by the FHWA's Office of Highway Policy Information (OHPI), was held in Washington, D.C., on January 7, 2003. Representatives from EIA, EPA, U.S. Department of Agriculture (USDA), U.S. Department of Treasury, RFA, and ORNL, as well as a field expert representing the U.S. Department of Energy (DOE) and a private consultant were invited to join FHWA in discussions of gasohol issues. The workshop participants were asked to help FHWA in identifying emerging issues that might impact estimates of future gasohol consumption and to make recommendations on how to address these issues. It was recognized that, through this effort, participating agencies would all benefit from having more accurate gasohol consumption statistics.

During the workshop, participants were told that FHWA is emphasizing data quality in FHWA products. FHWA is trying to shift the focus of data quality to the State (i.e., source of data) before the submittal. Because the accountability for data quality is placed on the States, FHWA is developing tools that can assist States to improve their data quality. In this context, the gasohol model posed one of the primary issues. Specifically, FHWA needs to be able to respond with logical and reasonable explanations when States raise questions on estimates produced from the gasohol model. Furthermore, FHWA needs to know how to deal with changes expected for gasohol usage in the near future.

The following sections briefly summarize the inputs provided by various organizations that participated in the gasohol improvement workshop.

\subsection{EIA VIEW}

EIA conducts a monthly ethanol production and stocks survey. This production survey cannot be used directly for the gasohol estimation model because the data are not at the State level. EIA publications that might be of some use include the Petroleum Supply Monthly and the Petroleum Marketing Monthly. ${ }^{11}$ Particularly, Table 48 of the Petroleum Marketing Monthly, which provides State-level gasoline sales by grade and type, was recommended to FHWA as one of the best data sources for gasohol estimation. Unfortunately, each of the potential data sources had certain limitations - e.g., confidentiality of the data or aggregation issues when trying to separate gasohol gallons from gallons of fuel oxygenates that are not gasohol.

Although EIA uses forecasting models, it does not do forecasting on ethanol or gasohol. EIA generally obtains the natio nal ethanol estimates from USDA. EIA frequently conducts

\footnotetext{
${ }^{11}$ Information available online at http://www.eia.doe.gov/oil gas/petroleum/data publications/petroleum supply monthly/psm.html and http://www.eia.doe.gov/oil gas/petroleum/data publications/petroleum marketing monthly/pmm.html
} 
analysis on current problems and has looked at the supply impacts of the ban on MTBE in motor fuel. ${ }^{12}$

\subsection{PERSPECTIVE OF THE DOE FIELD EXPERT}

The DOE field expert noted that policies and incentives would have an impact on the gasohol fuel market. The DOE representative noted that the Clean Air Act specified that RFG must contain 2 weight-percent of oxygen (about $5.7 \%$ ethanol by volume) while oxygenated fuels must contain 2.7 percent oxygen by weight (about $7.7 \%$ ethanol by volume). He also mentioned potential impacts caused by the renewable fuel standard.

The field expert noted that current data gaps for gasohol are the following:

- Nationwide collection of State-level gasohol consumption, and

- Information on gasohol versus E85 production and usage.

A study done by Downstream Alternatives, Inc., for DOE, was mentioned as a potential data source for the gasohol model. This data set includes forecasts at the terminal level. ${ }^{13}$

\subsection{EPA ANALYSIS}

The EPA delegate discussed two data sets that are relevant to the gasohol issue. One, which is used for ensuring compliance by refiners and importers to RFG requirements, contains confidential business information and is unavailable for public use. The other data set is a survey of gas stations in RFG areas. This data set can be provided to other agencies after certain confidential business information is stripped out. This data set provides actual oxygen content information by area and season.

The EPA representative noted several factors that could affect ethanol use, including the MTBE bans, the RFG opt-outs, and the RFG oxygenate waivers. He also noted that there are some differences among EPA, FHWA, and EIA numbers for ethanol use in certain States. These differences might be caused by variation in the definitions.

\subsection{TREASURY REPORT}

The U.S. Department of Treasury discussed HTF-related activities within Treasury but had no recommendations for additional data sets that could be of use for the gasohol model. Under a partnership with FHWA, IRS is developing new data collection and reporting system, the Excise Files Information Retrieval System (ExFIRS). A major component of the ExFIRS, named Excise Summary Terminal Activity Reporting System (ExSTARS), is designed to

\footnotetext{
${ }^{12}$ Supply Impacts of an MTBE Ban, Office of Oil and Gas, Energy Information Administration, September 2002.

${ }^{13}$ Downstream Alternatives, Inc., Infrastructure Requirements for an Expanded Fuel Ethanol Industry, January $15,2002$.
} 
track all petroleum product movements, including gasohol, through approved terminals. The system also captures destination State information when the product is disbursed through the terminal rack. This new system is not yet complete, however. It is anticipated that fuel- use estimation models will no longer be necessary when the gallons of fuel by State destination are collected through the ExFIRS/ExSTARS in the future.

\subsection{USDA OPINION}

USDA representatives discussed results of analyses on ethanol production. There were no specific recommendations for additional data sets to improve the gasohol model. There was an extensive discussion on Federal policies, particularly subsidies, as they pertain to the ethanol and domestic oil industries. It was pointed out that most USDA analyses are related to agricultural economics and are on a national level (i.e., no State level details).

\subsection{RFA VIEW}

The RFA representative noted that policies influence fuel usage. He also noted that both consumers and industry want clean air and inexpensive fuels. Although no recommendations were made for new data sets for use with the gasohol model, it was noted that RFA has good contacts with terminals and is interested in working with FHWA.

\subsection{COMMENTS AND DISCUSSIONS}

A former contractor of the USDA discussed a study that was conducted for the USDA which determined State ethanol consumption using State fuel-testing data. Two sources of gasoline survey data were noted by this panelist: one conducted by TRW in 15 marketing regions twice a year and the other conducted by the American Automobile Manufacturers Association. Both of these data sets are limited, however. The most promising data is the State fuel-testing program conducted by many States for quality control purposes. These programs usually include tests for MTBE and ethanol. Some limitations exist in this data, however. They include: (1) variations in data collection frequencies; (2) use of assumptions, averaging, and smoothing; (3) difficulty in collecting the data; (4) gaps in the data (i.e., some States do not have this program); and (5) a lack of information on ethanol blending levels.

Participants of the Gasohol Model Improvement Workshop agreed that several pertinent comments may impact the future use of gasohol and, therefore, may need to be considered in the revision of the gasohol estimation model. These include: (1) the decrease in MTBE use could result in an increase in ethanol use; (2) regional concentrations of ethanol consumption could shift; (3) regional concentrations of ethanol production might shift; and (4) the reliability of future gasohol data is uncertain.

Furthermore, it was noted that data reliability has become more important in recent years. Congressional staff members are also paying more attention to the gasohol numbers and 
energy acts are expected to impact gasohol in the future. Currently, about $\$ 1.3$ billion annually is impacted due to gasohol usages. In addition to the 0.1 cent/gallon of fuel tax that goes to the LUST Fund, 2.5 cents/gallon is taken from gasohol taxes and placed into the General Fund. This practice is generally considered as a "loss" of revenue from the HTF.

Differences in definitions between non-attainment areas and RFG areas as well as distinctions among gasohol, oxyfuel, and E85 were also noted by the workshop participants. The importance of the proximity factor (as described in the regression-based model) was questioned by several panelists. It was pointed out that, in some situations, ethanol production plants may not necessarily be producing fuel ethanol.

\subsection{WORKSHOP RECOMMENDATIONS}

General consensus and recommendations from participants of the gasohol model improvement workshop are summarized as the following:

1. The workshop attendees agreed that a regression modeling approach, as used in the current gasohol model, is probably inappropriate.

2. The working group strongly recommended that FHWA take advantage of the RFG survey data from EPA. This data set has a sound coverage for the total ethanol used in RFG, including gasohol. It was recognized by the group as some of the best data available to meet FHWA needs. A limitation to this data set was also noted that the EPA data set only includes RFG, but not all gasohol is RFG. On the conventional gasoline side, it was suggested that results from the Downstream Alternatives, Inc., study might be of some use to the gasohol modeling. Further review of this information will be needed.

3. It was agreed that the State-testing program data has the potential to provide FHWA, at a minimum, with information needed to validate the State-submitted gasohol consumption data especially those with zero consumption. Further uses of this data might be identified after ORNL has an opportunity to review the data contents.

4. EXFIRS/EXSTARS has the potential to provide FHWA with needed data in the future. This system, however, is not ready for use at this time. 


\section{THE NEW RULE-BASED GASOHOL CONSUMPTION ESTIMATION MODEL}

\subsection{INTRODUCTION}

As stated earlier, FHWA has concerns on the regression-based gasohol consumption estimation model due to several of its weaknesses. The issues include:

1. The model is overly sensitive to even slight changes on the proximity score variable;

2. Its determination of a "good State" is too subjective and is not well justified;

3. The goodness of fit of the regression equation is questionable when applied with recent data;

4. Several computational errors identified during ORNL review of the model raised the data accuracy issue; and

5. The model does not have the ability to reflect the anticipated increase of gasohol usage caused by ongoing MTBE bans.

The upcoming reauthorization of the TEA-21, the Safe, Accountable, Flexible and Efficient Transportation Equity Act of 2003 (SAFETEA), also prompts a critical review of data quality and accuracy, particularly, on those factors used in formulas for HTF attribution purposes. With its increasing demand by the States, the gasohol issue has become much more important than before.

This chapter provides a description of the newly developed rule-based model by ORNL. Data sources and criteria (rules) used in determining State-level gasohol consumption are discussed. The major challenge is that the model needs to produce robust estimates of gasohol consumption by State and also needs to be able to capture the increases on gasohol usages induced by changes in MTBE polices. While the new IRS systems, EXFIRS and EXSTARS, have the potential to provide valuable information for tracking gasohol usage by State, results from these systems are not yet available.

The Gasohol Improvement Workshop conducted by FHWA in January 2003, played a crucial role in shaping the development of this rule-based model. New data sources were identified during the workshop and, subsequently, were provided through cooperation of various participating agencies.

\subsection{OVERVIEW OF THE RULE-BASED MODEL}

Similar to the regression-based gasohol estimation model, the rule-based gasohol estimation model was implemented as a spreadsheet application for FHWA use. There are three major processes in the rule-based model - one to compute the control total from the amount of revenue collected by the Treasury, one to determine gasohol usage for "reliable data" States, and one to estimate the gasohol usage for States that fail all rules. Figure 4 presents an 


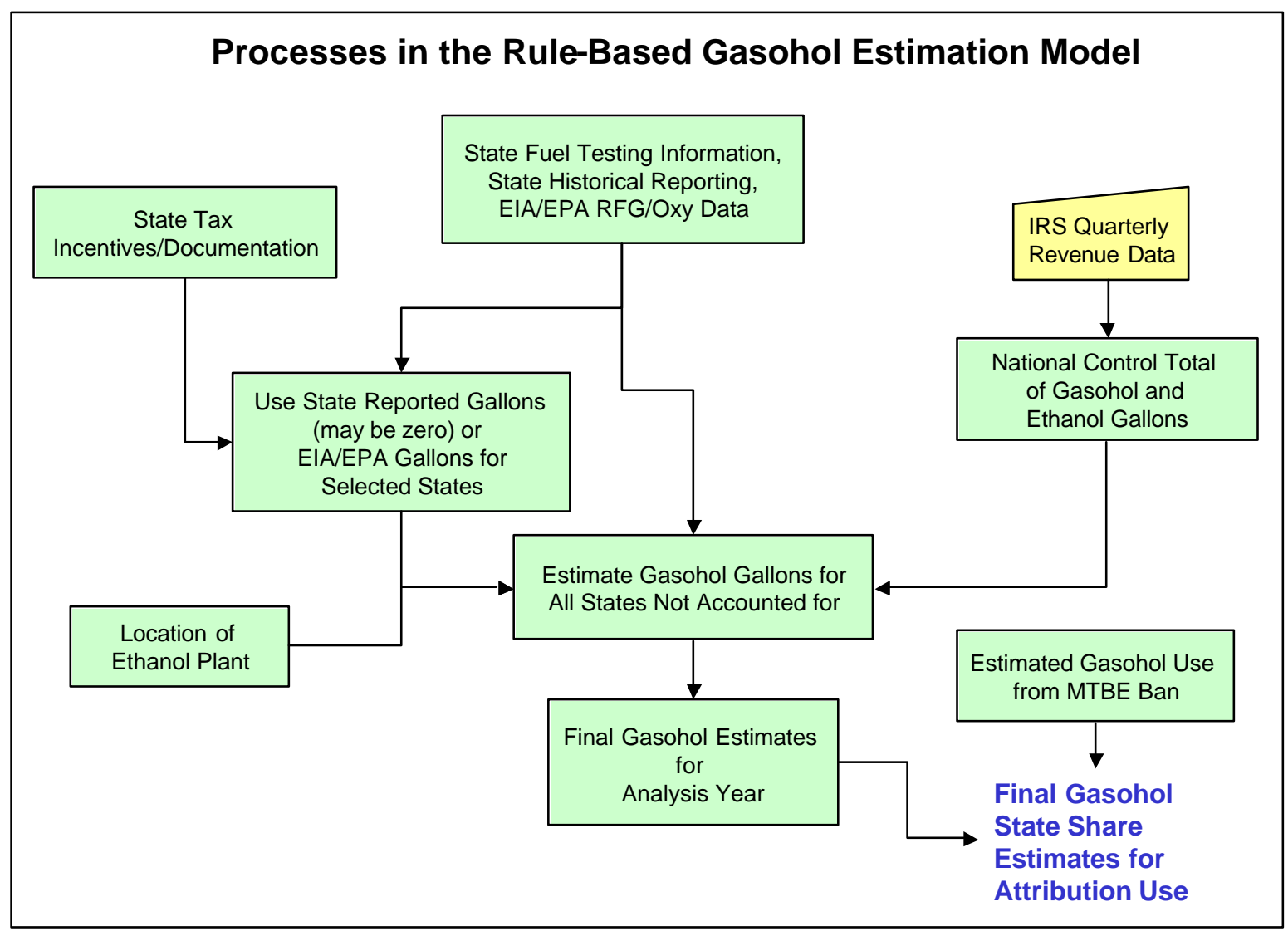

Figure 4. Overview of the new rule-based gasohol consumption estimation model.

overview of processes contained within the new rule-based model. More specific flowcharts and additional details concerning the rule-based process are provided in Sections 5.3-5.5.

Primary data sources for this model are the Treasury-provided quarterly HTF revenue and associated refunds and credits data, State-reported fuel usage as presented in Table MF33GA of the Highway Statistics, RFG survey data provided by EPA, and Table 48 of the Petroleum Marketing Annual published by EIA. These data sets are described in Section 5.3. For further information, a listing of the data sources used in both the regression-based and the rule-based models, along with additional information such as data provider and update frequencies, are provided in Appendix $\mathrm{C}$ of this report.

The most significant revision to FHWA's gasohol estimation concept is the change from a regression-based to a rule-based approach for estimating gasohol consumption for States that must be estimated. A process description for the new rule-based methodology is provided in Section 5.4 .

The new rule-based gasohol model also features more automation in its processes and is equipped with many data protections to prevent accidental overwrite of important formulas. Furthermore, data entry was kept at a minimum to reduce user burden as well as to decrease any potential errors during data entries. The user-interface of the new rule-based model was 
also designed to be as user-friendly as possible. For example, spreadsheet cells in the new model are color coded and annotated to identify where data entry is required. The spreadsheet file and its user interface are described in Section 5.5.

To evaluate several assumptions used in the rule-based gasohol model and to ensure robustness of the model results, ORNL conducted a sensitivity analysis. A discussion of this analysis is provided in Section 5.6 and scenario results are provided in Appendix E.

\subsection{REVIEW OF DATA SOURCES}

During the development of the new rule-based gasohol model, several data sources, including some previously used in the regression-based model, were reviewed. The review also included performing some data analysis using these data sets. The process is briefly described in this section.

\subsubsection{State-reported Fuel Usage}

Because FHWA-551M is the primary input mechanism for the States to submit usage data to FHWA, it is a critical data feed for the model. State-reported gasoline and gasohol data are included in Tables MF-33GA and MF-33GLA, respectively, by FHWA. Although not all States are able to ascertain their actual gasohol usage, the States that can report reliable usage data form the backbone of the gasohol model.

\subsubsection{Quarterly HTF Revenue Data and Tax Rates}

The IRS quarterly reports provide the total amount of Federal tax revenue that has been collected and certified to HTF on gasohol usage in the nation. Because this is the most reliable information currently available, this revenue data (dollars) are used to estimate a national total usage (in gallons), which is then applied as a control total in the gasohol model. Table 1 shows the quarterly HTF revenues for calendar year (CY) 2001. Note that refunds and credits have been subtracted from the total revenue presented in this table.

\subsubsection{EIA Publication}

The EIA surveys gasoline suppliers in each State on a monthly basis using Form EIA-782C, "Monthly Report of Prime Supplier Sales of Petroleum Products Sold for Local Consumption." The results of this survey are published in the Petroleum Marketing Annual, Table 48, which lists prime supplier sales volumes of motor gasoline by grade (i.e., regular, midgrade, premium) and type [i.e., conventional, oxygenated (oxy), reformulated] by State. Supplier sales can be used as a proxy for gasoline use within the State, although they do not indicate the amount of gasohol use within a State. Combined with other sources of information (e.g., EPA), these data (Table 2) are used in the new rule-based model. 


\begin{tabular}{|c|c|c|c|c|c|}
\hline & \begin{tabular}{c|} 
Qtr (Jan- \\
Mar) 2001 \\
\end{tabular} & $\begin{array}{c}\text { Qtr (Apr-Jun) } \\
2001 \\
\end{array}$ & $\begin{array}{c}\text { Qtr (Jul-Sep) } \\
2001 \\
\end{array}$ & \begin{tabular}{|c|} 
Qtr (Oct-Dec) \\
2001 \\
\end{tabular} & $\begin{array}{c}\text { Annual Total Tax } \\
\text { Revenue } 2001 \\
\end{array}$ \\
\hline Gasohol sold & $\$ 527,483,000$ & $\$ 421,029,000$ & $\$ 411,223,000$ & \begin{tabular}{|l|l|}
$560,946,000$ \\
\end{tabular} & $\$ \mathbf{\$ 1 , 9 2 0 , 6 8 1 , 0 0 0}$ \\
\hline Gasohol sold - $10 \%$ & $\$ 367,021,044$ & $\$ 361,611,481$ & $\$ 348,559,691$ & $\$ 388,774,237$ & $\$ 1,465,966,452$ \\
\hline Gasohol sold $-7.7 \%$ & $\$ 58,947,863$ & $\$ 2,511,228$ & $\$ 3,327,294$ & $\$ 79,854,287$ & $\$ 144,640,672$ \\
\hline Gasohol sold $-5.7 \%$ & $\$ 101,514,093$ & $\$ 56,906,291$ & $\$ 59,336,015$ & $\$ 92,317,477$ & $\$ 310,073,876$ \\
\hline Gas for gasohol & $\$ 39,543,000$ & $\$ 46,497,000$ & $\$ 44,151,000$ & $\$ 52,744,000$ & $\$ 182,935,000$ \\
\hline Gas for gasohol - $10 \%$ & $\$ 37,383,672$ & $\$ 46,033,384$ & $\$ 44,096,334$ & $\$ 50,097,366$ & $\$ 177,610,756$ \\
\hline Gas for gasohol $-7.7 \%$ & $\$ 2,153,882$ & $\$ 463,616$ & $\$ 54,666$ & $\$ 2,628,844$ & $\$ 5,301,007$ \\
\hline Gas for gasohol $-5.7 \%$ & $\$ 5,447$ & $\$ 0$ & $\$ 0$ & $\$ 17,791$ & $\$ 23,237$ \\
\hline \multicolumn{5}{|l|}{ TOTAL } & $\$ 2,103,616,000$ \\
\hline \multicolumn{6}{|c|}{$\begin{array}{l}{ }^{a} \text { Three grades are combined on IRS refund and credit reports. Refund and credit calculations assume same } \\
\text { proportions between blends as excise tax returns. } \\
\text { Sources: Department of the Treasury, Internal Revenue Service, official correspondence containing Highway } \\
\text { Trust Fund (HTF) certification for processing quarters during various time frames. }\end{array}$} \\
\hline
\end{tabular}

\begin{tabular}{|c|c|c|c|c|c|}
\hline \multirow[b]{2}{*}{ State } & \multicolumn{4}{|c|}{ All grades (thousand gallons per day) } & \multirow{2}{*}{$\begin{array}{c}\text { Gasoline } \\
\text { in } \\
\text { RFG/oxy } \\
\text { areas (\%) }\end{array}$} \\
\hline & $\begin{array}{c}\text { Conventional } \\
\text { gasoline }\end{array}$ & $\begin{array}{c}\text { Oxygenated } \\
\text { gasoline }\end{array}$ & $\begin{array}{l}\text { Reformulated } \\
\text { gasoline }\end{array}$ & Total gasoline & \\
\hline Alabama & 6,312 & 0 & 0 & 6,312 & $0.00 \%$ \\
\hline Alaska & 631 & 130 & $\overline{0}$ & 761 & $17.08 \%$ \\
\hline Arizona & 2,100 & 383 & 3,642 & 6,126 & $65.71 \%$ \\
\hline \begin{tabular}{|l|} 
Arkansas \\
\end{tabular} & 3,740 & 0 & 0 & 3,740 & $0.00 \%$ \\
\hline California & 71 & 0 & 40,800 & 40,871 & $99.83 \%$ \\
\hline Colorado & 3,694 & 1,751 & 0 & 5,445 & $32.16 \%$ \\
\hline Connecticut & 0 & 0 & 4,059 & 4,059 & $100.00 \%$ \\
\hline Delaware & 0 & 0 & 1,215 & 1,215 & $100.00 \%$ \\
\hline District of Columbia & 0 & 0 & 302 & 302 & $100.00 \%$ \\
\hline Florida & 20,584 & 0 & 0 & 20,584 & $0.00 \%$ \\
\hline Georgia & 13,077 & 0 & 0 & 13,077 & $0.00 \%$ \\
\hline Hawaii & 1,074 & 0 & 0 & 1,074 & $0.00 \%$ \\
\hline Idaho & 1,642 & 0 & 0 & 1,642 & $0.00 \%$ \\
\hline Illinois & 4,983 & 0 & 7,378 & 12,361 & $59.69 \%$ \\
\hline Indiana & 7,293 & 0 & 1,128 & 8,421 & $13.39 \%$ \\
\hline Iowa & 4,133 & 0 & 0 & 4,133 & $0.00 \%$ \\
\hline Kansas & 3,885 & 0 & 0 & 3,885 & $0.00 \%$ \\
\hline Kentucky & 4,409 & 0 & 1,467 & 5,876 & $24.97 \%$ \\
\hline Louisiana & 5,950 & 0 & 0 & 5,950 & $0.00 \%$ \\
\hline Maine & 2,079 & 0 & 0 & 2,079 & $0.00 \%$ \\
\hline Maryland & 649 & 0 & 5,506 & 6,155 & $89.46 \%$ \\
\hline Massachusetts & 0 & 0 & 7,293 & 7,293 & $100.00 \%$ \\
\hline Michigan & 12,954 & 0 & 0 & 12,954 & $0.00 \%$ \\
\hline Minnesota & 141 & 6,673 & 0 & 6,814 & $97.94 \%$ \\
\hline Mississippi & 4,143 & 0 & 0 & 4,143 & $0.00 \%$ \\
\hline Missouri & 6,431 & 0 & 2,062 & 8,493 & $24.28 \%$ \\
\hline Montana & 1,363 & 18 & 0 & 1,380 & $1.30 \%$ \\
\hline Nebraska & 2,283 & 0 & 0 & 2,283 & $0.00 \%$ \\
\hline
\end{tabular}




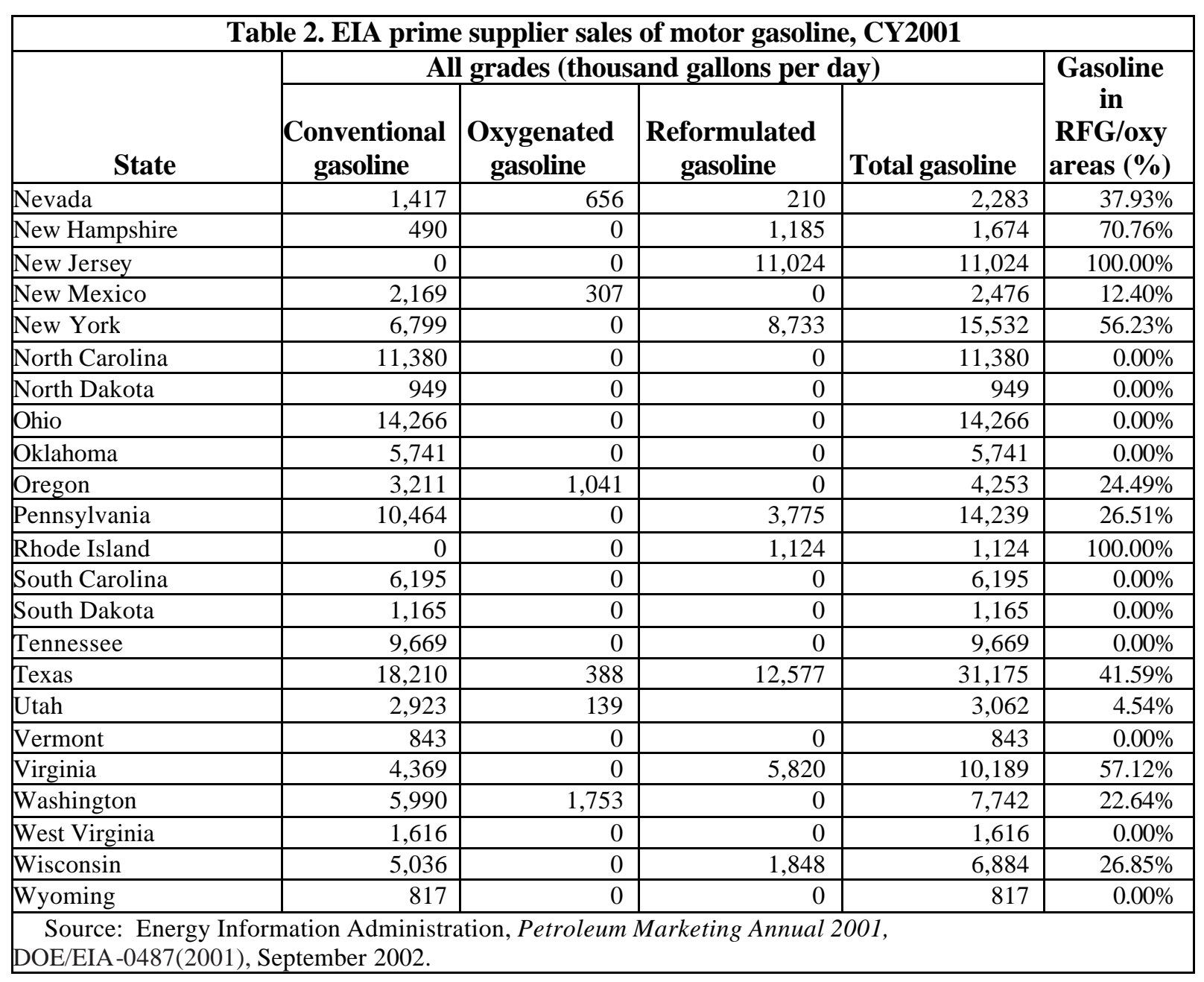

\subsubsection{EPA RFG Survey Data}

The RFG Survey Association, Inc., is a not-for-profit association of refiners, importers, and blenders of RFG and RFG blend stock for oxygenate blending. One task of the RFG Survey Association is to complete an annual comprehensive survey program on behalf of its members and to deliver the survey results to the EPA. This is in compliance with $40 \mathrm{CFR}$ $\S \S 80.67$ and 80.68 . $^{14}$ Over 150 surveys are conducted under this program each year, which results in a total of more than 10,000 individual samples collected and analyzed. ${ }^{15}$ The data resulting from this survey include the oxygen content of the fuel by weight and the type of oxygenate(s) the fuel contains. By analyzing the survey data, one can estimate the share of samples that are gasohol, by Federal definitions (i.e., volume content $5.7 \%$ and up to $10 \%$ )

\footnotetext{
${ }^{14}$ RFG Survey Association, Inc., “2003 Complex Model RFG Compliance Survey Plan” submitted to the United States Environmental Protection Agency, August 27, 2002.

15 Environmental Protection Agency, "Information on Reformulated Gasoline (RFG) Properties and Emissions Performance by Area and Season - Methodology and Explanation," http://www.epa.gov/otaq/regs/fuels/rfg/properf/perfmeth.htm .
} 
for each State where the sample was collected. The share of samples that use other oxygenates, such as MTBE, can also be determined. Table 3 provides the estimated shares for MTBE and gasohol (in three blends) based on the 2001 RFG Survey data. These estimated shares are used in conjunction with the EIA data in the rule-based model.

\begin{tabular}{|c|c|c|c|c|c|c|}
\hline \multirow[b]{3}{*}{ State } & \multicolumn{5}{|c|}{ Table 3. EPA RFG shares, 2001} & \multirow[b]{3}{*}{ Total } \\
\hline & \multicolumn{5}{|c|}{ Shares of all RFG, 2001 survey } & \\
\hline & MTBE & $\begin{array}{c}5.7 \% \\
\text { ethanol }\end{array}$ & $\begin{array}{c}7.7 \% \\
\text { ethanol }\end{array}$ & $\begin{array}{c}10 \% \\
\text { ethanol }\end{array}$ & Other & \\
\hline California & $87.8 \%$ & $11.7 \%$ & $0.0 \%$ & $0.0 \%$ & $0.5 \%$ & $100.0 \%$ \\
\hline Connecticut & $99.5 \%$ & $0.3 \%$ & $0.0 \%$ & $0.0 \%$ & $0.2 \%$ & $100.0 \%$ \\
\hline Delaware & $100.0 \%$ & $0.0 \%$ & $0.0 \%$ & $0.0 \%$ & $0.0 \%$ & $100.0 \%$ \\
\hline Dis trict of Columbia & $100.0 \%$ & $0.0 \%$ & $0.0 \%$ & $0.0 \%$ & $0.0 \%$ & $100.0 \%$ \\
\hline Illinois & $0.0 \%$ & $0.1 \%$ & $4.1 \%$ & $95.8 \%$ & $0.0 \%$ & $100.0 \%$ \\
\hline Indiana & $0.0 \%$ & $1.1 \%$ & $0.0 \%$ & $98.9 \%$ & $0.0 \%$ & $100.0 \%$ \\
\hline Kentucky & $65.5 \%$ & $0.9 \%$ & $0.0 \%$ & $33.2 \%$ & $0.4 \%$ & $100.0 \%$ \\
\hline Maryland & $100.0 \%$ & $0.0 \%$ & $0.0 \%$ & $0.0 \%$ & $0.0 \%$ & $100.0 \%$ \\
\hline Massachusetts & $98.3 \%$ & $1.4 \%$ & $0.3 \%$ & $0.0 \%$ & $0.1 \%$ & $100.0 \%$ \\
\hline Missouri & $74.3 \%$ & $2.4 \%$ & $0.5 \%$ & $18.3 \%$ & $4.4 \%$ & $100.0 \%$ \\
\hline New Hampshire & $100.0 \%$ & $0.0 \%$ & $0.0 \%$ & $0.0 \%$ & $0.0 \%$ & $100.0 \%$ \\
\hline New Jersey & $99.5 \%$ & $0.3 \%$ & $0.0 \%$ & $0.0 \%$ & $0.2 \%$ & $100.0 \%$ \\
\hline New York & $99.5 \%$ & $0.3 \%$ & $0.0 \%$ & $0.0 \%$ & $0.3 \%$ & $100.0 \%$ \\
\hline Pennsylvania & $99.6 \%$ & $0.0 \%$ & $0.0 \%$ & $0.0 \%$ & $0.4 \%$ & $100.0 \%$ \\
\hline Rhode Island & $98.0 \%$ & $1.0 \%$ & $0.0 \%$ & $0.5 \%$ & $0.5 \%$ & $100.0 \%$ \\
\hline Texas & $100.0 \%$ & $0.0 \%$ & $0.0 \%$ & $0.0 \%$ & $0.0 \%$ & $100.0 \%$ \\
\hline Virginia & $100.0 \%$ & $0.0 \%$ & $0.0 \%$ & $0.0 \%$ & $0.0 \%$ & $100.0 \%$ \\
\hline Wisconsin & $0.0 \%$ & $0.2 \%$ & $10.0 \%$ & $89.8 \%$ & $0.0 \%$ & $100.0 \%$ \\
\hline
\end{tabular}

\subsubsection{EPA State Winter Oxygenate Fuel Data}

The areas covered by the State Winter Oxygenated Fuel Program are mandated by the EPA to use oxy-fuel during the winter months in order to reduce $\mathrm{CO}$ emissions (Table 4). The EPA maintains a list of the areas, the amount of oxygen in the fuel, the type of oxygenate used, and the dates of the control period. ${ }^{16}$ This information, combined with the EIA data on oxy-fuel sales in each State, can be used to estimate the amount of gasohol used in the winter oxy-fuels areas.

\footnotetext{
${ }^{16}$ Environmental Protection Agency, "State Winter Oxygenated Fuel Program Requirements for Attainment or Maintenance of CO NAAQS," http://www.epa.gov/otaq/regs/fuels/oxy-area.pdf.
} 


\begin{tabular}{|l|l|c|c|}
\hline \multicolumn{4}{|c|}{ Table 4. Winter oxygenated fuel program requirements } \\
as of October 2001
\end{tabular}

\subsubsection{RFA Report on Ethanol Production Plant Locations}

As discussed in Section 3.2.4.1, the regression equation in the former model relied heavily on a factor that considered the capacity of ethanol production plants located in, or adjacent to, a State. Attendees at the Gasohol Model Improvement Workshop felt that the proximity factor was not necessarily a good factor. This conclusion was based on the fact that a State might have an ethanol plant but not use gasohol within that State, as for example, is true for Tennessee. ${ }^{17}$ The ethanol produced by the plant in Tennessee is not used for gasohol anywhere in the South, but is shipped to places where oxygenated gasoline is in demand for air quality purposes. ${ }^{18}$

In addition, ORNL pointed out during the Workshop that the proximity factor was used in four of the eight factors in the regression equation and cautioned about its excessive impact on the model estimates. This criticism of the excessive use of this variable, however, was primarily on the amount of weight given to this factor in the regression equation. Geographic proximity to an ethanol production plant is a logical and reasonable factor because of the physical properties of ethanol. Ethanol has a propensity to combine with water, which implies that the transport of ethanol over long distances provides its own set of problems.

\footnotetext{
17 Jennings, Randy, Tennessee Weights and Measures Office, personal communication with Stacy Davis, February 26, 2003.

${ }^{18}$ Downs, Joe, Ethanol Production Supervisor at A.E. Staley, Loudon, TN, personal communication with Stacy Davis, May 20, 2003.
} 
These problems are not insurmountable; however, they are a consideration, as is cost of transporting the ethanol when long distances are involved. A modified proximity to an ethanol plant factor was adopted in the new rule-based gasohol model. This factor is used in determining, when all other rules failed, the likelihood of gasohol use within a State.

\subsubsection{State Comments}

Previously, in the regression-based gasohol model, States that are not using gasohol (zero States) were determined based on information collected from the 1999 Battelle survey. Because changes in State fuel use patterns likely have occurred since the 1999 survey, ORNL considered information collected under that survey as possibly outdated.

Following the suggestion received at the Gasohol Model Improvement Workshop, the potential use of State fuel-testing program information was evaluated by ORNL. It was found that many States have a Weights and Measures Department (W\&MD) that conducts tests on the properties of gasoline sold in the State. This program is designed to protect the consumer by making sure that the gasoline is properly labeled. Due to lack of specific volume data, this information is expected to be useful for the confirmation of "zero States."

The initial list of "zero States" to be confirmed was compiled using information from the regression-based gasohol model estimates. Additional States were added into the contact list as needs for contacting such States arose during the course of model development. In this process, ORNL contacted W\&MDs in these States to verify that States reporting zero gasohol usage on their FHWA-551M were reporting accurately.

Several of the States contacted had no gasoline testing program in place, but they tested the gasoline pumps for accurate pumping measurements. Though some W\&MDs were unable to provide any information on gasohol use, most of the States which were thought to be "zero States" were confirmed by the W\&MD to have no gasohol sold in the State. Although not all States were contacted, all States that were expected to have zero usage were called. (See Appendix D for additional details.)

\subsubsection{State Ethanol Incentives}

Some States offer incentives for the production, blending, or use of ethanol. DOE keeps track of each State's incentives in an on-line database. ${ }^{19}$ This database was explored for all incentives dealing with ethanol production, ethanol blending, and gasohol use. Incentives for the use of E-85 or E-100 were not considered.

States with gasohol incentives are listed in Table 5. There are currently 15 States offering incentives for the production of ethanol within the State and two States offering other types of ethanol incentives, such as tax credits to retail stations which sell ethanol-blended fuel, or tax deductions for using ethanolblended fuel. Some States also offer an excise tax exemption for gasohol, so that it is taxed at a lower rate than gasoline. The FHWA publishes

\footnotetext{
${ }^{19}$ Department of Energy, “Alternative Fuel Vehicle Fleet Buyer's Guide Incentives and Laws,” http://www.fleets.doe.gov/fleet tool.cgi?27519,benefits,2,3957.
} 
State fuel taxes on Table MF-121T in the Highway Statistics. The most recent data are current as of January 1, 2001, and show that four States have gasohol exemptions (Table 5). States with tax exemptions on gasohol are assumed to have reliable data on gasohol use due to data collected in the revenue collection process.

\begin{tabular}{|l|c|c|c|}
\hline \multicolumn{4}{|c|}{ Table 5. State gasohol incentives } \\
\hline \multicolumn{1}{|c|}{ State } & $\begin{array}{c}\text { Producer } \\
\text { incentives }\end{array}$ & $\begin{array}{c}\text { State tax } \\
\text { incentives }\end{array}$ & $\begin{array}{c}\text { Other } \\
\text { incentives }^{a}\end{array}$ \\
\hline Arkansas & $\checkmark$ & & \\
\hline Connecticut & & $\checkmark$ & \\
\hline Hawaii & $\checkmark$ & & \\
\hline Idaho & $\checkmark$ & & \\
\hline Illinois & $\checkmark$ & & \\
\hline Indiana & $\checkmark$ & $\checkmark$ & $\checkmark$ \\
\hline Iowa & $\checkmark$ & & \\
\hline Kansas & $\checkmark$ & & \\
\hline Maine & $\checkmark$ & & \\
\hline Minnesota & $\checkmark$ & & \\
\hline Missouri & $\checkmark$ & & \\
\hline Montana & $\checkmark$ & & \\
\hline Nebraska & $\checkmark$ & & \\
\hline North Carolina & $\checkmark$ & $\checkmark$ & \\
\hline North Dakota & $\checkmark$ & $\checkmark$ & \\
\hline Ohio & $\checkmark$ & & \\
\hline South Dakota & \multicolumn{1}{l|}{} \\
\hline Wyoming & ${ }^{a}$ E-85 incentives are not included. \\
$\begin{array}{l}\text { Source: Department of Energy, “Alternative Fuel Vehicle Fleet } \\
\text { Buyer's Guide, Incentives and Laws," } \\
\text { http://www.fleets.doe.gov/fleet_tool.cgi?27519,benefits,2,3957. }\end{array}$ \\
\hline \hline
\end{tabular}

\subsubsection{Bans on the Use of MTBE}

The Clean Air Act and its amendments require the use of an oxygenate in motor fuel in certain areas of the States to reduce harmful emissions. Since 1992, some States have used the fuel additive MTBE as an oxygenate. However, as pointed out previously, MTBE has environmental consequences to groundwater and many States have banned, or are in the process of banning, its use. The bans on MTBE use are expected to increase the use of ethanol in many States, because ethanol can also be used as an oxygen enhancer in motor fuel. It is generally anticipated that areas banning MTBE could likely be shifting to ethanol to fulfill environmental requirements.

With respect to the concern of increasing ethanol supply due to the banning of MTBE, USDA has conducted an analysis on economic effects of replacing MTBE by ethanol. 
According to this study, USDA has concluded that a 4-year adjustment period is sufficient to enable ethanol production and distribution capacity to expand to meet the projected increase in demand. ${ }^{20}$ Under the rule-based model development, therefore, it is assumed that ethanol production capacity is of no concern. In other words, this study assumes that there will be enough ethanol to replace MTBE in gasoline. Furthermore, in the new rule-based model, it is assumed that ethanol will replace MTBE as the fuel oxygen and that the result will mostly be a $5.7 \%$ blend of gasohol in the State. This assumption is based on the rationale that many refiners will not use the higher amounts of blending because of economical and emission constraint reasons.

Table 6 shows the States that currently disallow or are planning to ban the use of MTBE. The effective date of these bans is also listed in this table. Although there are 17 States that currently have MTBE bans or phase-outs, not all are presently using MTBE. Much of the Midwest has banned MTBE, but it is not being used in that area, so the MTBE bans will not cause any impact on ethanol use in these States. The States that will incur additional ethanol use by banning MTBE (as of 2003) will be Connecticut, California, New York, Missouri, and Kentucky. ${ }^{21}$

\begin{tabular}{|l|c|}
\hline \multicolumn{2}{|c|}{$\begin{array}{c}\text { Table 6. States that are banning MTBE in gasoline } \\
\text { (listing as of April 2003, in chronological order) }\end{array}$} \\
\hline \multicolumn{1}{|c|}{ State $^{a}$} & Month-year of ban \\
\hline Iowa & March-01 \\
\hline Minnesota & March-01 \\
\hline Nebraska & March-01 \\
\hline South Dakota & March-01 \\
\hline Michigan & June-01 \\
\hline Colorado & April-02 \\
\hline Arizona & June-03 \\
\hline Connecticut & October-03 \\
\hline California & December-03 \\
\hline New York & January-04 \\
\hline Illinois & July-04 \\
\hline Indiana & July-04 \\
\hline Kansas & July-04 \\
\hline Washington & 2004 \\
\hline Missouri & July-05 \\
\hline Ohio & July-05 \\
\hline Kentucky & January-06 \\
\hline${ }^{a}$ Target is no more than 0.5\% MTBE for Missouri, Indiana, \\
and Kansas; target is no more than 1.0\% MTBE for Nebraska. \\
Source: Shirley, Chuck, Energy Information \\
Administration, Oxygenates Price Master spreadsheet. \\
\hline
\end{tabular}

20 "Economic Analysis of Replacing MTBE with Ethanol in the United States, USDA, January 2000, http://www.ethanolrfa.org/usda.html.

${ }^{21}$ Lidderdale, Tancred, EIA, personal communication with Stacy Davis, March 13, 2003. 


\subsubsection{Other Data Sources Reviewed}

Several other data sources were also recommended by participants of the Gasohol Improvement Workshop. These data were not used in the rule-based gasohol model for various reasons, as explained below.

The Petroleum Supply Annual, published by EIA, contains data that are collected by a survey at the refinery, so anything blended with ethanol at the refinery is captured in the survey. However, according to EIA, almost half of all ethanol is NOT blended at the refinery. Furthermore, data provided in this report are not broken down to the State level. Therefore, it was not recommended for the use in the gasohol model.

ORNL also looked at the possibility of using corn production, or other agricultural commodity of feedstock production, as a factor in estimating ethanol production with the States. The Agriculture Census is only conducted every five years, however. Based on the timeliness of this data, ORNL determined that Agriculture Census data would not be appropriate for FHWA applications.

Two other reports providing data on ethanol terminal capacities - Petroleum Terminal Encyclopedia by Oil Price Information Service ${ }^{22}$ and Infrastructure Requirements for an Expanded Ethanol Industry produced by Downstream Alternatives, Inc. ${ }^{23}$ were recommended by a panelist of the Gasohol Model Improvement Workshop. The Petroleum Terminal Encyclopedia contains a listing of terminals by State and individual storage capacity of ethanol and gasoline. Infrastructure Requirements for an Expanded Ethanol Industry contains forecasted case studies on ethanol use by PADD (Petroleum Administration for Defense District) and forecasted ethanol capacities by individual terminal.

As a result from the review of these reports, it was determined that terminal capacity is not meaningful in itself. Throughput is necessary to tell how much ethanol and gasoline are really used. In addition, storage terminals located in a State intuitively indicate that a product is used within the State but are no guarantee of this assumption. Therefore, this information was not used in the new rule-based model.

\subsection{PROCESS DESCRIPTION OF THE RULE-BASED GASOHOL MODEL}

The processes used in the new gasohol estimation model are described in this section. Flow charts illustrating these processes, as well as rules applied in determining the flows, are also provided.

\subsubsection{Computing the Control Totals}

Every quarter, FHWA obtains IRS processed and certified HTF revenue data on gasohol and gasoline-to-be-used-in-gasohol (gas for gasohol) from the Treasury Department. These revenue data are national totals and are provided by the three gasohol blending levels.

\footnotetext{
${ }^{22}$ Oil Price Information Service, Petroleum Terminal Encyclopedia, 2002/2003.

${ }^{23}$ Downstream Alternatives, Inc., Infrastructure Requirements for an Expanded Ethanol Industry, 2002.
} 
FHWA also obtains refunds and credits on gasohol and gas-for-gasohol from the Treasury on a quarterly basis. These refunds and credits are not separated by gasohol blends, however.

The gasohol revenue data from Treasury provide the most reliable information currently available, at the national level. Since FHWA is interested in gasohol usage in gallons, conversion from the total dollars to total gallons is necessary. To arrive at total fuel gallons, the revenue dollars are divided by the tax rate. Table 7 shows the excise tax rates and the portion of the excise taxes that must be removed because they are not deposited into the HTF. Table 8 shows the estimated total U.S. gallons of gasohol consumed during CY2001, as calculated from the IRS tax revenues. This is used as the "control total" for this time period.

Table 7. Federal excise tax rates during CY2001 on gasohol and gas used for gasohol

\begin{tabular}{|c|c|c|c|c|}
\hline & $\begin{array}{c}\text { Qtr (Jan-Mar) } \\
2001\end{array}$ & $\begin{array}{c}\text { Qtr (Apr-Jun) } \\
2001\end{array}$ & $\begin{array}{c}\text { Qtr (Jul-Sep) } \\
2001\end{array}$ & $\begin{array}{c}\text { Qtr (Oct-Dec) } \\
2001\end{array}$ \\
\hline \multicolumn{5}{|c|}{ Excise tax rate (cents per gallon) } \\
\hline \multicolumn{5}{|l|}{ Gasohol sold } \\
\hline Gasohol sold $-10 \%$ & $\$ 0.13000$ & $\$ 0.13000$ & $\$ 0.13000$ & $\$ 0.13100$ \\
\hline Gasohol sold $-7.7 \%$ & $\$ 0.14242$ & $\$ 0.14242$ & $\$ 0.14242$ & $\$ 0.14319$ \\
\hline Gasohol sold $-5.7 \%$ & $\$ 0.15322$ & $\$ 0.15322$ & $\$ 0.15322$ & $\$ 0.15379$ \\
\hline \multicolumn{5}{|l|}{ Gas for gasohol } \\
\hline Gas for gasohol $-10 \%$ & $\$ 0.14444$ & $\$ 0.14444$ & $\$ 0.14444$ & $\$ 0.14555$ \\
\hline Gas for gasohol $-7.7 \%$ & $\$ 0.15430$ & $\$ 0.15430$ & $\$ 0.15430$ & $\$ 0.15513$ \\
\hline Gas for gasohol $-5.7 \%$ & $\$ 0.16248$ & $\$ 0.16248$ & $\$ 0.16248$ & $\$ 0.16308$ \\
\hline \multicolumn{5}{|c|}{ Portion of tax rate for non-HTF (cents per gallon) } \\
\hline \multicolumn{5}{|l|}{ Gasohol sold } \\
\hline Gasohol sold - $10 \%$ & $\$ 0.02600$ & $\$ 0.02600$ & $\$ 0.02600$ & $\$ 0.02600$ \\
\hline Gasohol sold $-7.7 \%$ & $\$ 0.02600$ & $\$ 0.02600$ & $\$ 0.02600$ & $\$ 0.02600$ \\
\hline Gasohol sold $-5.7 \%$ & $\$ 0.02600$ & $\$ 0.02600$ & $\$ 0.02600$ & $\$ 0.02600$ \\
\hline \multicolumn{5}{|l|}{ Gas for gasohol } \\
\hline Gas for gasohol - $10 \%$ & $\$ 0.02600$ & $\$ 0.02600$ & $\$ 0.02600$ & $\$ 0.02600$ \\
\hline Gas for gasohol $-7.7 \%$ & $\$ 0.02600$ & $\$ 0.02600$ & $\$ 0.02600$ & $\$ 0.02600$ \\
\hline Gas for gasohol $-5.7 \%$ & $\$ 0.02600$ & $\$ 0.02600$ & $\$ 0.02600$ & $\$ 0.02600$ \\
\hline
\end{tabular}

Table 8. Estimated total U.S. gasohol consumption, CY2001

\begin{tabular}{|c|r|}
\hline Fuel type & $\begin{array}{c}\text { Consumption estimates } \\
\text { (thousand gallons) }\end{array}$ \\
\hline Gasohol sold (total) & $\mathbf{1 7 , 7 3 2 , 1 9 4}$ \\
\hline Gasohol sold $-10 \%$ & $14,060,229$ \\
\hline Gasohol sold $-7.7 \%$ & $1,237,897$ \\
\hline Gasohol sold $-5.7 \%$ & $2,434,068$ \\
\hline Gas for gasohol (total) & $\mathbf{1 , 5 3 7 , 0 1 2}$ \\
\hline Gas for gasohol $-10 \%$ & $1,495,657$ \\
\hline Gas for gasohol $-7.7 \%$ & 41,186 \\
\hline Gas for gasohol $-5.7 \%$ & 170 \\
\hline Total gasohol gallons (thousands) & $\mathbf{1 9 , 2 6 9 , 2 0 6}$ \\
\hline
\end{tabular}




\subsubsection{Determining the States with Zero Gasohol Usage}

The status of "zero State" was determined based on results from contacts with State W\&MD (see Section 5.3.7) and information from the Highway Statistics 2001, Table MF-27 for the latest year, and Table MF-33GLA for the last three years. In addition, EIA and EPA data regarding RFG or oxygenated fuel requirements were also considered in this process. When results from all sources agreed that there was no gasohol usage in the State, it is considered as a reliable "zero State." This process confirmed that 13 States are in this category, including Arkansas, Delaware, the District of Columbia, Georgia, Hawaii, Maine, Mississippi, New Hampshire, Oklahoma, South Carolina, Tennessee, Vermont, and Wyoming. Information used and the resulting status of States are listed in Table 9.

\begin{tabular}{|c|c|c|c|c|c|c|}
\hline \multicolumn{7}{|c|}{ Table 9. Method for determining "zero" States } \\
\hline State & \begin{tabular}{|c|} 
\\
FHWA \\
zero States $^{a}$ \\
\end{tabular} & $\begin{array}{c}\text { State gasoline } \\
\text { testing } \\
\text { program } \\
\text { zero States }^{b}\end{array}$ & $\begin{array}{l}\text { Reporting } \\
\text { zero in the } \\
\text { latest year }\end{array}$ & $\begin{array}{l}\text { Reporting } \\
\text { zero in last } \\
\text { three years }{ }^{d}\end{array}$ & $\begin{array}{c}\text { RFG or } \\
\text { oxygenated } \\
\text { fuel area } \\
\text { using gasohol }^{e}\end{array}$ & Consistent? \\
\hline Alabama & $\mathrm{N}$ & $\mathrm{N}$ & $\mathrm{Y}$ & $\mathrm{N}$ & & \\
\hline Alaska & $\mathrm{N}$ & & $\mathrm{N}$ & $\mathrm{N}$ & RFG/OXY & non-zero \\
\hline Arizona & $\mathrm{N}$ & $\mathrm{N}$ & $\mathrm{Y}$ & $\mathrm{Y}$ & RFG/OXY & \\
\hline Arkansas & $\mathbf{Y}$ & $\mathbf{Y}$ & $\mathbf{Y}$ & $\mathbf{Y}$ & & ZERO \\
\hline California & $\mathrm{N}$ & & $\mathrm{Y}$ & $\mathrm{Y}$ & RFG/OXY & \\
\hline Colorado & $\mathrm{N}$ & & $\mathrm{N}$ & $\mathrm{N}$ & RFG/OXY & non-zero \\
\hline Connecticut & $\mathrm{N}$ & & $\mathrm{N}$ & $\mathrm{N}$ & RFG/OXY & non-zero \\
\hline Delaware & $\mathbf{Y}$ & - & $\mathbf{Y}$ & $\mathbf{Y}$ & & ZERO \\
\hline $\begin{array}{l}\text { District of } \\
\text { Columbia }\end{array}$ & $\mathbf{Y}$ & $\mathbf{Y}$ & $\mathbf{Y}$ & $\mathbf{Y}$ & & ZERO \\
\hline Florida & $\mathrm{N}$ & $\mathrm{N}$ & $\mathrm{N}$ & $\mathrm{N}$ & & non-zero \\
\hline Georgia & $\mathbf{Y}$ & $\mathbf{Y}$ & $\mathbf{Y}$ & $\mathbf{Y}$ & & ZERO \\
\hline Hawaii & $\mathbf{Y}$ & $\mathbf{Y}$ & $\mathbf{Y}$ & $\mathbf{Y}$ & & ZERO \\
\hline Idaho & $\mathrm{Y}$ & $\mathrm{N}$ & $\mathrm{Y}$ & $\mathrm{Y}$ & & \\
\hline Illinois & $\mathrm{N}$ & & $\mathrm{N}$ & $\mathrm{N}$ & RFG/OXY & non-zero \\
\hline Indiana & $\mathrm{N}$ & & $\mathrm{N}$ & $\mathrm{N}$ & RFG/OXY & non-zero \\
\hline Iowa & $\mathrm{N}$ & & $\mathrm{N}$ & $\mathrm{N}$ & & non-zero \\
\hline Kansas & $\mathrm{N}$ & & $\mathrm{N}$ & $\mathrm{N}$ & & non-zero \\
\hline Kentucky & $\mathrm{N}$ & & $\mathrm{N}$ & $\mathrm{N}$ & RFG/OXY & non-zero \\
\hline Louisiana & $\mathrm{N}$ & & $\mathrm{N}$ & $\mathrm{N}$ & & non-zero \\
\hline Maine & $\mathbf{Y}$ & $\mathbf{Y}$ & $\mathbf{Y}$ & $\mathbf{Y}$ & & ZERO \\
\hline Maryland & $\mathrm{N}$ & - & $\mathrm{Y}$ & $\mathrm{Y}$ & & \\
\hline Massachusetts & $\bar{Y}$ & & $\mathrm{Y}$ & $\bar{Y}$ & RFG/OXY & \\
\hline Michigan & $\mathrm{N}$ & & $\mathrm{N}$ & $\mathrm{N}$ & & non-zero \\
\hline Minnesota & $\mathrm{N}$ & & $\mathrm{N}$ & $\mathrm{N}$ & RFG/OXY & non-zero \\
\hline Mississippi & $\mathbf{Y}$ & $\mathbf{Y}$ & $\mathbf{Y}$ & $\mathbf{Y}$ & & ZERO \\
\hline Missouri & $\mathrm{N}$ & & $\mathrm{N}$ & $\mathrm{N}$ & RFG/OXY & non-zero \\
\hline Montana & $\mathrm{N}$ & & $\mathrm{N}$ & $\mathrm{N}$ & RFG/OXY & non-zero \\
\hline Nebraska & $\mathrm{N}$ & & $\mathrm{N}$ & $\mathrm{N}$ & & non-zero \\
\hline Nevada & $\mathrm{N}$ & & $\mathrm{N}$ & $\mathrm{N}$ & RFG/OXY & non-zero \\
\hline New Hampshire & $\mathbf{Y}$ & $\mathbf{Y}$ & $\mathbf{Y}$ & $\mathbf{Y}$ & & ZERO \\
\hline
\end{tabular}




\begin{tabular}{|c|c|c|c|c|c|c|}
\hline \multicolumn{7}{|c|}{ Table 9. Method for determining "zero" States } \\
\hline State & \begin{tabular}{|c|} 
\\
FHWA \\
zero States $^{a}$ \\
\end{tabular} & $\begin{array}{c}\text { State gasoline } \\
\text { testing } \\
\text { program } \\
\text { zero States } \\
b\end{array}$ & $\begin{array}{l}\text { Reporting } \\
\text { zero in the } \\
\text { latest year }\end{array}$ & $\begin{array}{l}\text { Reporting } \\
\text { zero in last } \\
\text { three years }{ }^{d}\end{array}$ & $\begin{array}{c}\text { RFG or } \\
\text { oxygenated } \\
\text { fuel area } \\
\text { using gasohol }\end{array}$ & Consistent? \\
\hline New Jersey & \begin{tabular}{|l|}
$\mathrm{N}$ \\
\end{tabular} & & $\mathrm{Y}$ & $\mathrm{Y}$ & RFG/OXY & \\
\hline New Mexico & $\mathrm{N}$ & $\mathrm{N}$ & $\mathrm{N}$ & $\mathrm{N}$ & RFG/OXY & non-zero \\
\hline New York & $\mathrm{N}$ & $\mathrm{N}$ & $\mathrm{Y}$ & $\mathrm{Y}$ & RFGOXY & \\
\hline North Carolina & $\mathrm{N}$ & $\mathrm{Y}$ & $\mathrm{N}$ & $\mathrm{N}$ & & \\
\hline North Dakota & $\mathrm{N}$ & & $\mathrm{N}$ & $\mathrm{N}$ & & non-zero \\
\hline Ohio & $\mathrm{N}$ & & $\mathrm{N}$ & $\mathrm{N}$ & & non-zero \\
\hline Oklahoma & $\mathbf{Y}$ & & $\mathbf{Y}$ & $\mathbf{Y}$ & & ZERO \\
\hline Oregon & $\mathrm{N}$ & & $\mathrm{Y}$ & $\mathrm{Y}$ & RFG/OXY & \\
\hline Pennsylvania & $\mathrm{N}$ & - & $\mathrm{Y}$ & $\mathrm{Y}$ & & \\
\hline Rhode Island & $\mathrm{Y}$ & & $\mathrm{Y}$ & $\mathrm{Y}$ & RFG/OXY & \\
\hline South Carolina & $\mathbf{Y}$ & $\mathbf{Y}$ & $\mathbf{Y}$ & $\mathbf{Y}$ & & ZERO \\
\hline South Dakota & $\mathrm{N}$ & & $\mathrm{N}$ & $\mathrm{N}$ & & non-zero \\
\hline Tennessee & $\mathbf{Y}$ & $\mathbf{Y}$ & $\mathbf{Y}$ & $\mathbf{Y}$ & & ZERO \\
\hline Texas & $\mathrm{N}$ & $\mathrm{N}$ & $\mathrm{N}$ & $\mathrm{N}$ & RFG/OXY & non-zero \\
\hline Utah & $\mathrm{N}$ & $\mathrm{N}$ & $\mathrm{Y}$ & $\mathrm{Y}$ & RFG/OXY & \\
\hline Vermont & $\mathbf{Y}$ & $\mathbf{Y}$ & $\mathbf{Y}$ & $\mathbf{Y}$ & & ZERO \\
\hline Virginia & $\mathrm{N}$ & $\mathrm{N}$ & $\mathrm{N}$ & $\mathrm{N}$ & & \\
\hline Washington & $\mathrm{N}$ & $\mathrm{N}$ & $\mathrm{N}$ & $\mathrm{N}$ & RFG/OXY & non-zero \\
\hline West Virginia & $\mathrm{N}$ & & $\mathrm{N}$ & $\mathrm{N}$ & & non-zero \\
\hline Wisconsin & $\mathrm{N}$ & & $\mathrm{N}$ & $\mathrm{N}$ & RFG/OXY & non-zero \\
\hline Wyoming & \begin{tabular}{|l|}
$\mathbf{Y}$ \\
\end{tabular} & & $\mathbf{Y}$ & $\mathbf{Y}$ & & ZERO \\
\hline \multicolumn{7}{|c|}{$\begin{array}{l}{ }^{a} \text { From Highway Statistics, 2001, Table MF-27. } \\
{ }^{d} \text { Based on phone interviews conducted by ORNL, 2003. A “-“ in this column implies that the } \\
\text { interview provided inconclusive results. } \\
{ }^{c} \text { From Highway Statistics, 2001, Table MF-33GLA. } \\
{ }^{d} \text { From Highway Statistics, 1999-2001, Table MF-33GLA. } \\
{ }^{e} \text { If a State has an RFG or oxygenated fuel requirement and uses gasohol to meet the requirement, } \\
\text { then it cannot be considered a zero State (see Tables } 2 \text { and 3). }\end{array}$} \\
\hline
\end{tabular}

\subsubsection{Determining the States with Reliable Data on Gasohol Usage}

The method for selecting the States with "reliable" data is based on the process described below. It should be noted that "reliable" can imply verifiable zero usage. Therefore, the 13 States identified through the process described above are also "reliable" States. The States identified in the following paragraphs have gasohol usage, and sufficient data exists to determine their gasohol usage.

\subsubsection{RFG/Oxy Areas and Gasohol Use}

EPA data on RFG areas and areas requiring oxygenated fuels were used to determine whether or not a State had RFG or oxygenate requirements. For the 27 States that include RFG/oxy areas, RFG survey data obtained from the EPA were used to estimate percent shares of gasohol blends used in each of these States. These shares were then applied to the oxygenated and RFG total gallons published by EIA to estimate gasohol uses in RFG/oxy 
areas within these States. States containing RFG areas or oxygenated fuel requirements and are using gasohol as oxygen in their fuel are noted in Table 9.

\subsubsection{Comparison of State-reported Gallons and EIA/EPA-based Estimates}

State-reported gasohol gallons from MF-33GLA for States with RFG/oxy areas were compared to the gallons derived from the previous step. If the State-reported gallons were greater than or equal to the EIA/EPA-based estimate for a given State, the gasohol gallons submitted by the State are accepted as they are reported. For the 2001 analysis year, ten States were in this category (Alaska, Connecticut, Illinois, Indiana, Minnesota, Missouri, Montana, Nevada, Texas, and Wisconsin).

If the State-reported gasohol gallons are less than the EIA/EPA-based estimate, the EIA/EPA-based estimate is used as a part of the State gasohol consumption. The assumption is that the EIA/EPA-based estimate is the minimum requirement and, therefore, a State with RFG/Oxy areas should at least use as much gasohol as this amount (i.e., EIA/EPA-based). For these States, additional estimation is needed to account for gasohol used outside the required RFG/oxy areas. This is further discussed in the next section.

\subsubsection{Use of Gasohol in RFG/Oxy States in Areas Outside the RFG/Oxy Areas}

Based on information obtained from the State contacts, States (with RFG/oxy areas) that reported less gallons than the amounts estimated from EIA/EPA-based method were classified into two categories. States being classified in the "not using gasohol outside RFG/oxy areas" were assigned gasohol consumption amounts equal to their EIA/EPA-based estimated gallons. For the 2001 analysis year, seven States (Arizona, California, Massachusetts, New Jersey, New Mexico, Rhode Island, and Utah) received this classification.

States that were classified as "using gasohol outside RFG/oxy areas" were assigned their EIA/EPA-based estimated gallons as part of their consumption. These States were also flagged as being incomplete because further computation is needed to account for the gasohol gallons used outside the RFG/oxy areas. For the 2001 analysis year, five States (Colorado, Kentucky, New York, Oregon, and Washington) received this classification.

All State consumption totals (either whole or partial) are tracked and summed to an "accounted-for" total for later use.

\subsubsection{Tax Incentives and/or Good Documentation}

It is assumed that States with gasohol tax incentives for consumers have some gasohol usage. That is, States that provide tax incentives on gasohol use, whether or not they contain RFG/oxy areas, are believed to have better tracking records of their gasohol consumption data. Therefore, gasohol gallon values as reported by these States were accepted.

States that have published, well-documented fuel consumption reports, or evidence of maintaining reliable data on historical fuel uses, were also considered to be accurately tracking their gasohol consumption data. Therefore, gasohol gallon values as reported by these States were also accepted. 
For the 2001 analysis year, seven States (Florida, Iowa, Idaho, Nebraska, North Dakota, Ohio, and South Dakota) were categorized as either having tax incentives or good documentation.

\subsubsection{Determining the "Not-Accounted-For" Gallons}

Quarterly HTF revenue data provided by IRS are arithmetically converted to gallons using appropriate tax rates for the three federally defined gasohol blends (Section 5.4.1). Refunds and credits (also from IRS) were deducted from the revenue data, and the portion of the tax rate that goes to non-HTF accounts was removed before the conversion to gallons. The resulting gasohol gallon total was then used as the U.S. control total.

Up to this point, gasohol gallons for all but 14 States (including five States that have been assigned a partial total) have been allocated, as described in Sections 5.4.2 and 5.4.3. The total "accounted-for" gallons (summing all amounts determined from the above processes up to this point) are then subtracted from the U.S. control total. The difference, the total "notaccounted-for" gallons, is the amount to be distributed among the 14 States that did not meet the criteria as described above.

The "not-accounted-for" gallons are distributed based on shares computed as described in next section. At the conclusion of this distribution, estimated gasohol consumption for all States in the analysis-year will be complete.

\subsubsection{Computing Gasohol Usage for Not-Accounted-for States}

For the 2001 analysis year, nine States (Alabama, Kansas, Louisiana, Maryland, Michigan, North Carolina, Pennsylvania, Virginia, and West Virginia) failed all rules used thus far. Five additional States (Colorado, Kentucky, New York, Oregon, and Washington) that failed certain rules were assigned with a partial gasohol allocation (Section 5.4.3.3). Gasohol consumption by each of these 14 States required to be estimated by the model.

The weights that were used in estimating the gasohol consumption for these States are as follows:

- All States were assigned an initial weight of 1 (i.e., equally weighted among all 14 States).

- A factor of 0.1 was multiplied to the above initial weight to assign gasohol usage to those States that used gasohol outside their RFG/oxy areas (i.e., those with a "partial" assignment of gallons). The resulting gasohol gallons are the extra amounts to be added to the EIA/EPA-based estimates for those States.

- For the States without EIA/EPA-based estimates (i.e., 9 States in 2001), a factor of 0.5 was added to the initial weight to assign gasohol usage to those States located within a 100-mile radius of an ethanol production plant (see Figure 2). The rational of this heavier weight is that being closer to a ethanol plant would increase the likelihood of using gasohol. An exception, as explained in Section 5.3.6, is for the ethanol plant in Tennessee. 
Thus, for the 14 States that require estimation for their gasohol usage, the conventional gasoline consumptions in these States were summed together to a total (e.g., T). An initial share amount (e.g., $S_{i}$ for State $i$ ) was computed by dividing its gallons (i.e., amount of conventional gasoline) by this total $\boldsymbol{T}$. These initial shares were then adjusted by weights assigned to each of the States involved, as described above.

By re-adjusting these weighted shares so they sum to $100 \%$, the final State shares for these 14 States were produced. The non-accounted for gallons (from Section 5.4.4) are then distributed to these 14 States using the shares obtained from this process. For a State that already has partial assignment, the gasohol amount obtained from this distribution is added to derive a final estimation of gasohol consumption for this State. Otherwise, the distributed amount is the gasohol consumption for the State.

\subsubsection{Process Flow}

The process flow described in Sections 5.4.2-5.4.5 is illustrated in Figures 5-7. Figure 5 shows the processes for determining zero States and for assigning gasohol gallons to States that have RFG or oxygenated fuel areas. Figure 6 shows the flows for evaluating the remaining States for reliable data and arriving at the "not-accounted-for" gallons from the U.S. control total. Figure 7 shows the data flows for computing the shares for the 14 States described in Section 5.4.5 - i.e., States that failed all of the rules. 


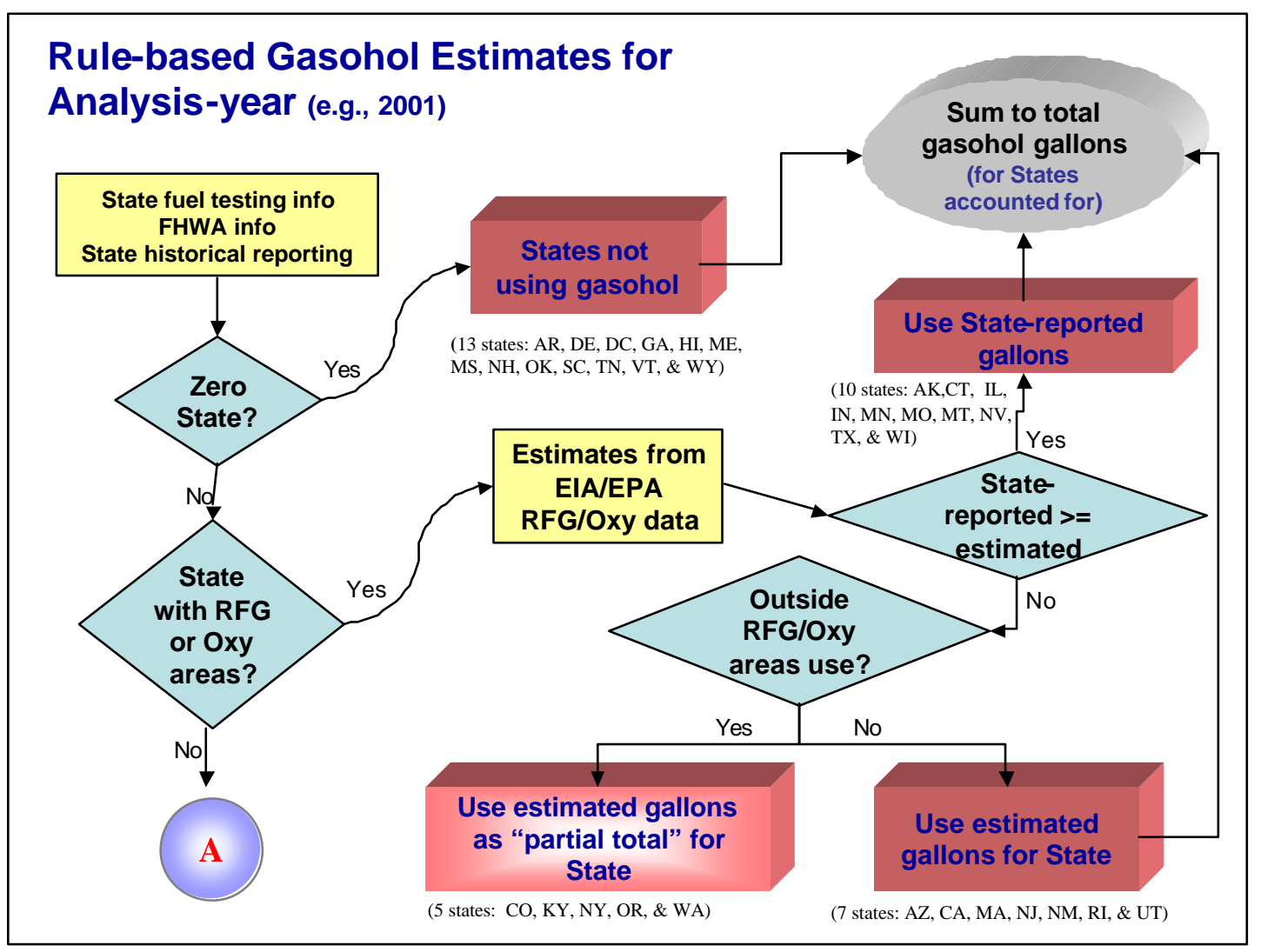

Figure 5. Flow chart of rule-based gasohol estimation model, Part 1:

determining zero States. Note that the States listed on this chart as fitting particular rules represent the data for the 2001 analysis year. Also note that "A" on this chart leads to Figure 6. 


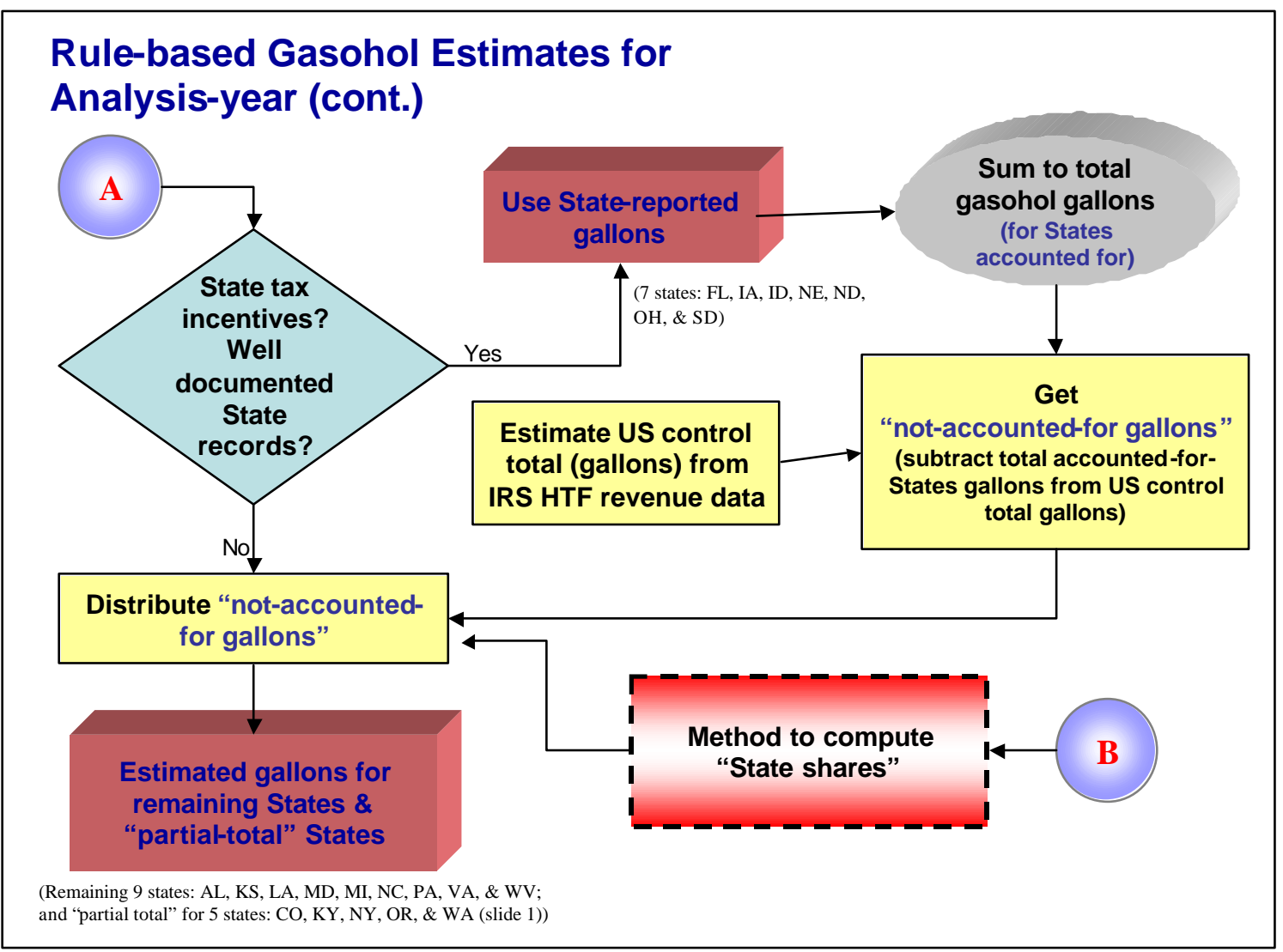

Figure 6. Flow chart of rule-based gasohol estimation model, Part 2: determing States with reliable gasohol data. Note that the States listed on this chart as fitting particular rules represent the data for the 2001 analysis year. Also note that "B" on this chart is represented in Figure 7. 


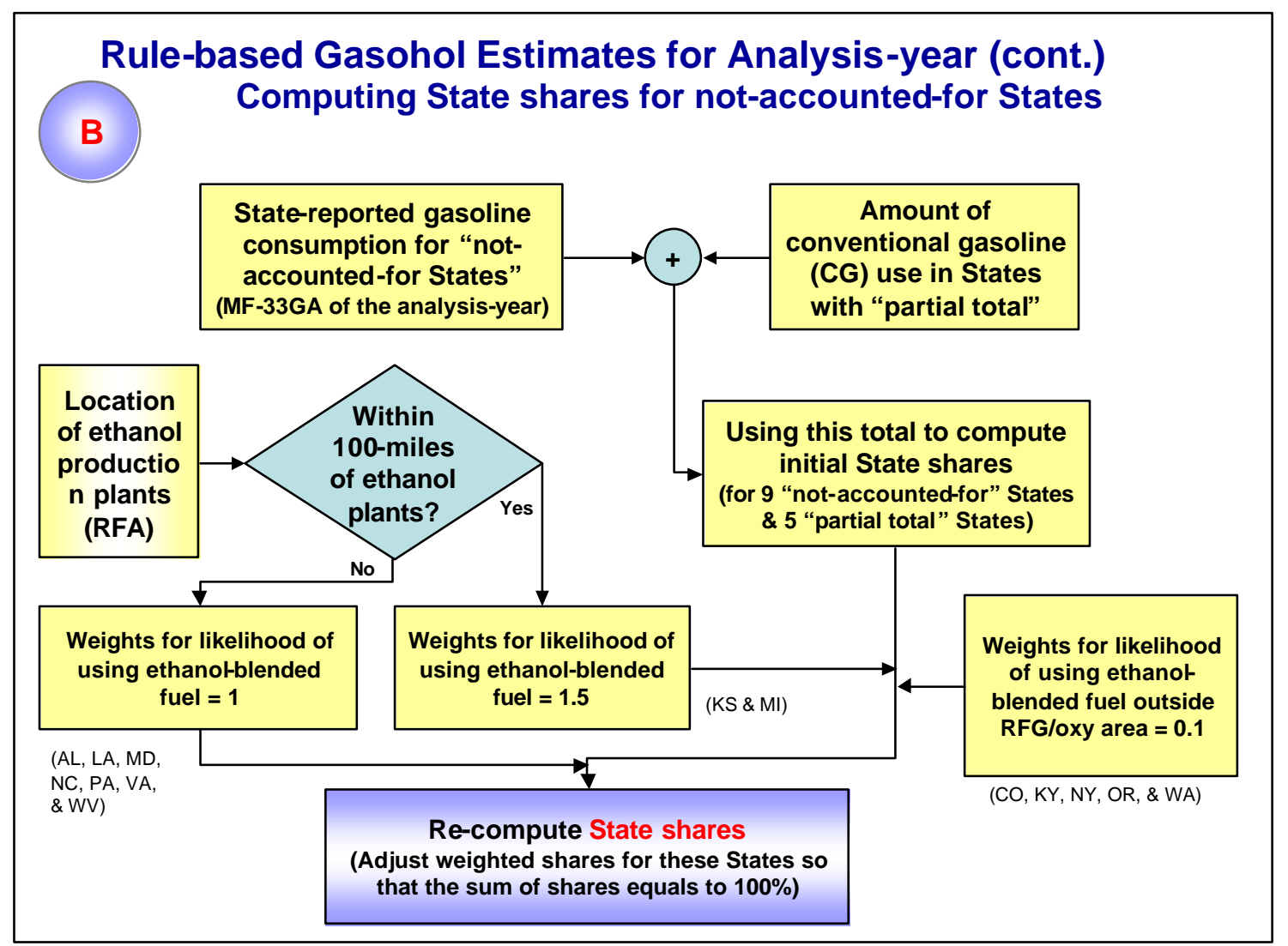

Figure 7. Flow chart of rule-based gasohol estimation model, Part 3: computing State shares for "not-accounted-for" States. Note that the States listed on this chart as fitting particular rules represent the data for the 2001 analysis year.

\subsubsection{Considering the Impact of MTBE Bans}

As discussed in Section 5.3.9, several States have proposed bans on the use of MTBE as an oxygenate. A gasohol blend of 5.7\% ethanol will be required to meet the RFG oxygen content requirement set forth in the 1990 CAA Amendments, Section 211(k). It is assumed that $100 \%$ of the gallons currently using MTBE will be replaced by ethanol. Currently, the model assumes that any phase-out of MTBE will occur at an even rate throughout the years before the ban's effective date as specified in State legislation (see Table 6). This assumption will be reevaluated under a follow-up study to estimate the impacts of MTBE bans.

Note that in the current model, the year in which the MTBE ban becomes effective is set to the given year if the month in which the ban becomes effective is before July; otherwise, the year in which the MTBE ban becomes effective is set to the year following the given year.

Figure 8 shows the approach used to estimate additional gasohol consumption in the year immediately following the analysis-year (e.g., 2002 for the analysis-year of 2001) to reflect possible impacts from State bans of MTBE. This approach also relies on EIA/EPA data for 


\section{Additional gasohol use due to MTBE ban, estimated for the year following the analysis-year (e.g., 2002 as "year+1")}

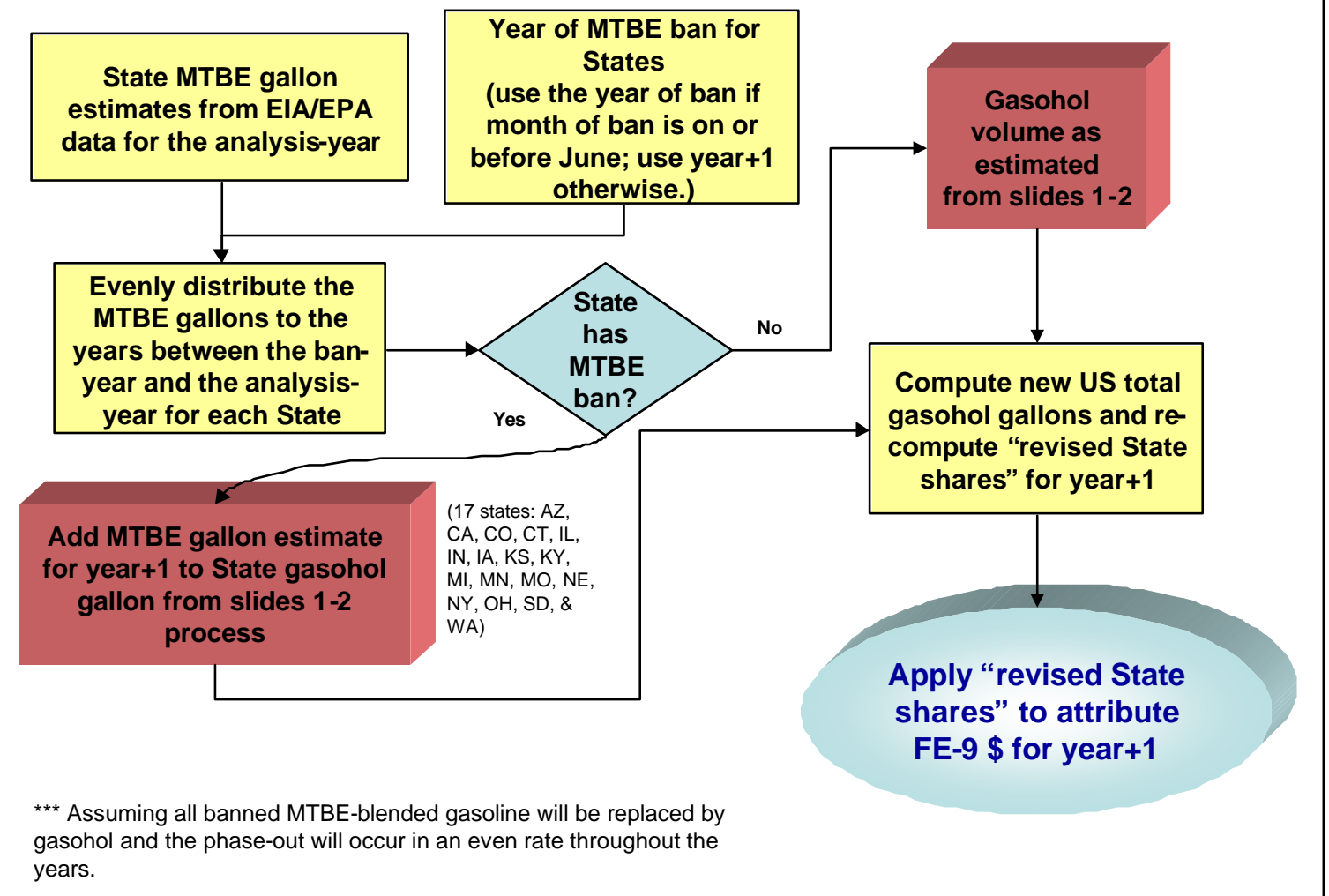

Figure 8. Flow chart of rule-based gasohol estimation model, Part 4: additional gasohol use due to MTBE ban, estimated for the year following the analysis year. Note that the States listed on this chart represent the data for 2002, the year following the 2001 analysis year considered throughout this document.

RFG/oxy areas. Total MTBE-blended gasoline gallons used by the State in the analysis-year are estimated based on these datasets.

The estimated gallons of MTBE-ban-induced gasohol for a State will be added to the State gasohol estimates derived as described in Sections 5.4.2-5.4.5, if there is a ban in its legislation. No changes will be made to States that do not ban MTBE. New totals and revised State shares will then be re-calculated. These revised State shares are used to attribute Federal tax collections by State (as found in the FHWA Table FE-9) for the year following the analysis-year.

\subsubsection{Summary}

In summary, the processes for the new rule-based gasohol estimation model use appropriate and reliable data sources and, based on a set of rules, determine whether the State-submitted data for gasohol consumption should be accepted as reported. If not, then the gasohol usage 
for the State is estimated using additional data sources. The results of the model for analysis year 2001 are shown in Table 10.

\begin{tabular}{|c|c|c|c|c|c|c|c|}
\hline \multicolumn{8}{|c|}{ Table 10. Estimates of gasohol consumption $(4 / 30 / 2003)$ for analysis year 2001} \\
\hline State & \begin{tabular}{|c|} 
First \\
estimate of \\
gasohol \\
use \\
(thousand \\
gallons) \\
\end{tabular} & $\begin{array}{c}\text { State- } \\
\text { reported } \\
\text { gasohol } \\
2001 \\
\text { (thousand } \\
\text { gallons) } \\
\end{array}$ & 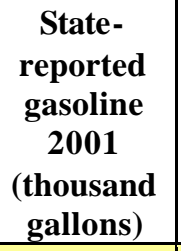 & \begin{tabular}{|c|} 
EIA/EPA- \\
based gasohol \\
consumption \\
estimates \\
(thousand \\
gallons) \\
\end{tabular} & \begin{tabular}{|c|} 
Estimate d \\
State \\
share for \\
2001 \\
\end{tabular} & \begin{tabular}{|c|} 
EIA/EPA- \\
based \\
consumption \\
+ MTBE ban \\
estimates \\
\end{tabular} & \begin{tabular}{|c|} 
Revised \\
shares for \\
attribution \\
purpose for \\
year 2002 \\
\end{tabular} \\
\hline Alabama $^{a}$ & FALSE & 0 & $2,458,241$ & 297,418 & $1.5 \%$ & 297,418 & $1.2 \%$ \\
\hline Alaska & 50,031 & 50,031 & 283,510 & 50,031 & $0.3 \%$ & 50,031 & $0.2 \%$ \\
\hline Arizona & 139,832 & 0 & $2,493,038$ & 139,832 & $0.7 \%$ & 139,832 & $0.6 \%$ \\
\hline Arkansas & 0 & 0 & $1,436,566$ & 0 & $0.0 \%$ & 0 & $0.0 \%$ \\
\hline California & $1,746,265$ & 0 & $14,966,704$ & $1,746,265$ & $9.1 \%$ & $6,103,923$ & $24.1 \%$ \\
\hline Colorado $^{b}$ & 639,006 & 475,835 & $2,139,619$ & 656,568 & $3.4 \%$ & 656,568 & $2.6 \%$ \\
\hline Connecticut & 11,009 & 11,009 & $1,496,468$ & 11,009 & $0.1 \%$ & 502,294 & $2.0 \%$ \\
\hline Delaware & 0 & 0 & 398,017 & 0 & $0.0 \%$ & 0 & $0.0 \%$ \\
\hline Dist. of Col. & 0 & 0 & 165,552 & 0 & $0.0 \%$ & 0 & $0.0 \%$ \\
\hline Florida & 9,716 & 9,716 & $7,713,972$ & 9,716 & $0.1 \%$ & 9,716 & $0.0 \%$ \\
\hline Georgia & 0 & 0 & $4,835,056$ & 0 & $0.0 \%$ & 0 & $0.0 \%$ \\
\hline Hawaii & 0 & 0 & 419,491 & 0 & $0.0 \%$ & 0 & $0.0 \%$ \\
\hline Idaho & 0 & 0 & 650,214 & 0 & $0.0 \%$ & 0 & $0.0 \%$ \\
\hline Illinois & $2,940,546$ & $2,940,546$ & $5,128,346$ & $2,940,546$ & $15.3 \%$ & $2,940,546$ & $11.6 \%$ \\
\hline Indiana & 984,201 & 984,201 & $3,227,409$ & 984,201 & $5.1 \%$ & 984,201 & $3.9 \%$ \\
\hline Iowa & 869,516 & 869,516 & $1,563,487$ & 869,516 & $4.5 \%$ & 869,516 & $3.4 \%$ \\
\hline Kansas $^{a}$ & FALSE & 21,751 & $1,312,618$ & 238,216 & $1.2 \%$ & 238,216 & $0.9 \%$ \\
\hline Kentucky $^{b}$ & 182,905 & 36,037 & $2,180,570$ & 202,700 & $1.1 \%$ & 272,811 & $1.1 \%$ \\
\hline Louisiana $^{a}$ & FALSE & 37 & $2,303,199$ & 278,659 & $1.4 \%$ & 278,659 & $1.1 \%$ \\
\hline Maine & 0 & 0 & 611,865 & 0 & $0.0 \%$ & 0 & $0.0 \%$ \\
\hline Maryland $^{a}$ & FALSE & 0 & $2,529,630$ & 306,055 & $1.6 \%$ & 306,055 & $1.2 \%$ \\
\hline Massachusetts & 43,481 & 0 & $2,806,176$ & & $0.2 \%$ & 43,481 & $0.2 \%$ \\
\hline Michigan $^{a}$ & FALSE & 201,889 & $5,074,963$ & & $4.8 \%$ & 921,014 & $3.6 \%$ \\
\hline Minnesota & $2,667,610$ & $2,667,610$ & $2,673,114$ & $2,667,610$ & $13.8 \%$ & $2,667,610$ & $10.5 \%$ \\
\hline Mississippi & 0 & 0 & $1,553,810$ & 0 & $0.0 \%$ & 0 & $0.0 \%$ \\
\hline Missouri & 235,968 & 235,968 & $3,115,135$ & 235,968 & $1.2 \%$ & 347,840 & $1.4 \%$ \\
\hline Montana & 13,215 & 13,215 & 499,609 & 13,215 & $0.1 \%$ & 13,215 & $0.1 \%$ \\
\hline Nebraska & 239,371 & 239,371 & 869,948 & 239,371 & $1.2 \%$ & 239,371 & $0.9 \%$ \\
\hline Nevada & 275,853 & 275,853 & 975,478 & 275,853 & $1.4 \%$ & 275,853 & $1.1 \%$ \\
\hline New Hampshire & 0 & 0 & 690,660 & 0 & $0.0 \%$ & 0 & $0.0 \%$ \\
\hline New Jersey & 11,865 & 0 & $3,998,940$ & 11,865 & $0.1 \%$ & 11,865 & $0.0 \%$ \\
\hline New Mexico & 112,055 & 79,154 & 936,373 & 112,055 & $0.6 \%$ & 112,055 & $0.4 \%$ \\
\hline New York ${ }^{b}$ & 8,269 & 0 & $5,679,011$ & 38,346 & $0.2 \%$ & $1,095,312$ & $4.3 \%$ \\
\hline North Carolina $^{a}$ & FALSE & 2,139 & $4,243,692$ & 513,436 & $2.7 \%$ & 513,436 & $2.0 \%$ \\
\hline North Dakota & 66,979 & 66,979 & 367,984 & 66,979 & $0.3 \%$ & 66,979 & $0.3 \%$ \\
\hline Ohio & $1,853,558$ & $1,853,558$ & $5,234,476$ & $1,853,558$ & $9.6 \%$ & $1,853,558$ & $7.3 \%$ \\
\hline Oklahoma & 0 & 0 & $1,830,320$ & 0 & $0.0 \%$ & 0 & $0.0 \%$ \\
\hline Oregon $^{b}$ & 380,111 & 0 & $1,546,270$ & 394,238 & $2.0 \%$ & 394,238 & $1.6 \%$ \\
\hline
\end{tabular}




\begin{tabular}{|c|c|c|c|c|c|c|c|}
\hline \multicolumn{8}{|c|}{ Table 10. Estimates of gasohol consumption $(4 / 30 / 2003)$ for analysis year 2001} \\
\hline State & \begin{tabular}{|c|} 
First \\
estimate of \\
gasohol \\
use \\
(thousand \\
gallons)
\end{tabular} & \begin{tabular}{|c|} 
State- \\
reported \\
gasohol \\
2001 \\
(thousand \\
gallons)
\end{tabular} & $\begin{array}{c}\text { State- } \\
\text { reported } \\
\text { gasoline } \\
2001 \\
\text { (thousand } \\
\text { gallons) }\end{array}$ & \begin{tabular}{|c|} 
EIA/EPA- \\
based gasohol \\
consumption \\
estimates \\
(thousand \\
gallons)
\end{tabular} & $\mid \begin{array}{c}\text { Estimate d } \\
\text { State } \\
\text { share for } \\
2001\end{array}$ & \begin{tabular}{|c|} 
EIA/EPA- \\
based \\
consumption \\
+ MTBE ban \\
estimates
\end{tabular} & $\begin{array}{c}\text { Revised } \\
\text { shares for } \\
\text { attribution } \\
\text { purpose for } \\
\text { year 2002 }\end{array}$ \\
\hline Pennsylvania $^{a}$ & FALSE & 0 & $5,148,222$ & 622,873 & $3.2 \%$ & \begin{tabular}{|r|}
622,873 \\
\end{tabular} & $2.5 \%$ \\
\hline Rhode Island & 6,120 & 0 & 409,510 & 6,120 & $0.0 \%$ & 6,120 & $0.0 \%$ \\
\hline South Carolina & 0 & 0 & $2,289,858$ & 0 & $0.0 \%$ & 0 & $0.0 \%$ \\
\hline South Dakota & 195,236 & 195,236 & 439,774 & 195,236 & $1.0 \%$ & 195,236 & $0.8 \%$ \\
\hline Tennessee & 0 & 0 & $2,935,176$ & 0 & $0.0 \%$ & 0 & $0.0 \%$ \\
\hline Texas & 311,693 & 311,693 & $10,937,243$ & 311,693 & $1.6 \%$ & 311,693 & $1.2 \%$ \\
\hline Utah & 50,772 & 0 & 997,214 & 50,772 & $0.3 \%$ & 50,772 & $0.2 \%$ \\
\hline Vermont & 0 & 0 & 342,691 & 0 & $0.0 \%$ & 0 & $0.0 \%$ \\
\hline Virginia $^{a}$ & FALSE & 44 & $3,862,056$ & 467,262 & $2.4 \%$ & 467,262 & $1.8 \%$ \\
\hline Washington $^{b}$ & 639,736 & 16,300 & $2,710,606$ & 665,106 & $3.5 \%$ & 665,106 & $2.6 \%$ \\
\hline West Virginia $^{a}$ & FALSE & 47,085 & 840,233 & 101,658 & $0.5 \%$ & 101,658 & $0.4 \%$ \\
\hline Wisconsin & 730,766 & 730,766 & $2,536,012$ & 730,766 & $3.8 \%$ & 730,766 & $2.9 \%$ \\
\hline Wyoming & 0 & 0 & 356,845 & 0 & $0.0 \%$ & 0 & $0.0 \%$ \\
\hline Total & $15,415,682$ & $12,335,540$ & $134,214,971$ & $19,269,206$ & $100.0 \%$ & $25,357,100$ & $100.0 \%$ \\
\hline \multicolumn{8}{|c|}{\begin{tabular}{|l|l|} 
IRS control total $=19,269,206$ & \\
\end{tabular}} \\
\hline \multicolumn{8}{|c|}{ Difference $=3,853,524$} \\
\hline \multicolumn{8}{|c|}{$\%$ to be distributed $=20.0 \%$} \\
\hline $\begin{array}{c}{ }^{a} \text { States label } \\
\text { consumption wa } \\
{ }^{b} \text { States label }\end{array}$ & with an " $a$ " a & are States th & at failed all rul & ales used in the & estimation $\mathrm{p}$ & rocess and their & ddition, \\
\hline
\end{tabular}

\subsection{DESCRIPTION OF THE USER INTERFACE}

The gasohol model was implemented as an Excel spreadsheet application and currently consists of six worksheets. These worksheets perform various operations and are briefly described as follows:

- Input-IRS data - this worksheet allows the FHWA analyst to enter quarterly revenue data and appropriate tax rates to be used for the model. All conversions, from dollars to gallons, are done automatically by the computer system.

- EPA data - this worksheet contains the EPA annual RFG-survey-derived percentages of MTBE and 5.7\%, 7.7\%, and 10\% ethanol in fuels in RFG areas by State.

- EIA data - this worksheet contains data from Table 48 of the EIA Petroleum Marketing Annual and applies EPA shares, from the EPA data worksheet, to derive the amount of fuel used in RFG/oxy areas by State.

- State information - this worksheet includes input data from MF-33GLA and MF33GA (FHWA-551M-based data) and several flags, for the "zero" States, States with tax incentives, States with good gasohol usage documentation, States within 
100 miles of an ethanol production plant, and States with RFG/oxy areas that also use ethanol outside the RFG/oxy areas.

- Output - this is the final result worksheet. It provides the final estimation of the gasohol gallons for the analysis year as well as State shares of the gasohol usage.

- MTBE information - this worksheet contains results from an assessment for States that have banned the use of MTBE. The estimated amount of gasohol use by States, which results from the MTBE ban for the year following the analysis year, is provided. This amount is to be added to the gasohol estimates obtained from the Output sheet to estimate State shares for HTF attribution purpose in the year following the analysis year.

Computations and cell linkages are automated whenever possible within the rule-based gasohol model spreadsheet application. Data entries have been kept to a minimum and all formulas are protected against accidental overwrites. In addition, a color-coding scheme is used throughout the worksheets. The color codes represent areas in which annual data entry is required (e.g., the IRS quarterly revenue statements), data entry that is only required when changes occur (e.g., updates to tax rates), and cells that are automatically filled in by the model (i.e., no data entries required).

The spreadsheet file is fully documented, and annotations on certain cells also provide reminders to FHWA concerning the data and/or process.

\subsection{SENSITIVITY ANALYSIS OF THE RULE-BASED MODEL}

To ensure the robustness of results generated from the rule-based gasohol model, ORNL has conducted a sensitivity analysis to evaluate several assumptions used in the model. Eight different scenarios were evaluated and compared with the base case scenario (Scenario 1). These scenarios are:

Scenario 1: Base case, the model as documented in this report.

Scenario 2: Assumption of 150-mile radius around an ethanol plant instead of 100 miles.

Scenario 3: Assumption of 200-mile radius around an ethanol plant instead of 100 miles.

Scenario 4: Assumption of 250-mile radius around an ethanol plant instead of 100 miles.

Scenario 5: Weight factor of 0.2 instead of 0.1 for the partially allocated States.

Scenario 6: Weight factor of 1.2 instead of 1.5 for States within 100-mile of ethanol plant.

Scenario 7: Weight factor of 2 instead of 1.5 for States within 100-mile of ethanol plant.

Scenario 8: Weight factor of 0.2 instead of 0.1 for the partially allocated States AND 2 instead of 1.5 for States within 100-mile of ethanol plant.

Scenario 9: Weight factor of 0.2 instead of 0.1 for the partially allocated States AND 1.2 instead of 1.5 for States within 100-mile of ethanol plant.

Results generated based on each of these scenarios are summarized and presented in tables included in Appendix E of this report. Differences from the base case are also listed in these tables. 
As noted above, three scenarios were selected to evaluate the distance assumption concerning proximity of a State to an ethanol production plant. Based on results summarized in Appendix E, changing the radius assumption from the base case of 100 miles to 150 or 200 miles has no impact on estimated State shares produced from the rule-based gasohol model. When changing the radius to 250 miles, some impact appears; almost all States are touched by the "circles" at this level. The only exceptions are Louisiana and the New England States.

Scenarios 5 through 9 were designed to evaluate the sensitivity of varying the "likelihood" weights used in the rule-based gasohol model. These weights only affect States that have their gasohol usage estimated because they fail all other rules. Under the base case scenario, if a State is categorized as a "partially allocated" State, it receives a weight of 0.1 for the "likelihood of ethanol use." This value was changed to 0.2 under scenarios 5, 8, and 9. Also, under the base case scenario, States within 100 miles radius of an ethanol plant are given a weight of 1.5 in the "likelihood of ethanol use" column. This value was changed to 1.2 under Scenarios 6 and 9, and changed to 2.0 under Scenarios 7 and 8.

As shown in Appendix E, Scenario 5 has very limited impacts on the States; the greatest percent difference from the base case is only $0.15 \%$. Changes for Scenarios 6-7 show slightly more variation. Michigan is affected the most under these two scenarios. The difference, however, is still relatively small, at about $1 \%$ under Scenario 7.

Note that none of the results presented in Appendix E included any extra MTBE estimates. The scenarios were designed to evaluate certain assumptions used in rules within the gasohol model. The additional gasohol usage induced from the MTBE ban does not use these assumptions and, therefore, are not considered in these comparisons. 



\section{SUMMARY AND CONCLUSIONS}

Gasohol usage has been increasing over the past ten years and, because of environmental concerns, it is expected to continue to increase. With the upcoming reauthorization of the TEA-21 (i.e., SAFETEA), Congress is also taking more notice of gasohol issues. A growing concern of data quality in general, and a commitment to its improvement, has prompted FHWA to initiate critical reviews on various data collection methods and estimation models used in its operations. On the gasohol side, this includes a review of the consumption estimation process and the identification of reliable alternatives (data and methodology). Particularly, FHWA needs to have a way to capture gasohol increases due to the policy changes in MTBE. As noted by participants in the Gasohol Model Improvement Workshop, revisions to the model might also be necessary to reflect future Federal emission policy mandates or changes.

The technical assessment of the regression-based model noted that the regression equation lacked robustness because of an overemphasis on the importance of the proximity to an ethanol production plant. This made the gasohol model overly sensitive to a slight change on the variable. In addition, the model allowed negative values for ethanol consumption, which is illogical. Finally, there were several mathematical errors in the model. These included the following:

- The appropriate reference locations for each quarterly spreadsheet did not accurately reflect the percentages for blend separations for refunds and credits.

- The tax rates in the model were not revised as changes occurred to the tax rate.

- Gallons representing refunds and credits for ethanol used for blending were added to, rather than subtracted from, overall gasohol consumption.

- Non-HTF taxes were not removed before converting the IRS revenue to gallons of gasohol.

After a thorough review of the earlier estimation model, ORNL reviewed potential new data sources, many of which were recommended by participants at the Gasohol Model Improvement Workshop. ORNL then developed a new rule-based model. The rule-based model employs the following rules:

- Determine whether gasohol is NOT used by a State (i.e., is this a "zero" State?).

- Determine whether the State has RFG/oxy areas, and, if so, estimate the amount of gasohol use in these areas (i.e., EIA/EPA-based estimates).

- Compare State-reported gasohol gallons to EIA/EPA-based estimates.

- Determine if gasohol is used outside the RFG/oxy areas.

- Determine whether tax incentives are provided by a State or whether the State has well-documented records.

- Convert the HTF revenue data provided by IRS to gallons, and determine the total gallons that have not yet been accounted for. 
- Compute State shares for distributing the "not-accounted-for" gallons, applying weights based on likelihood factors.

- Incorporate impacts of MTBE bans for the year following the analysis year, and recalculate the State shares.

Based on a sensitivity analysis on the new rule-based gasohol estimation model, State shares (on gasohol usage) estimated from this model were found to be reasonably robust. Further research on model procedures and relevant data will be pursued by FHWA as needed. Refinements to the gasohol consumption estimates will then be made if warranted. FHWA is continuing its efforts to solicit comments and inputs from all interested parties.

Finally, it is recommended that in future revisions of the gasohol estimation model, the new IRS systems, ExFIRS and ExSTARS, when fully operational, should be evaluated to assess their potential in determining gasohol usage. 


\section{REFERENCES}

Andress, David, Ethanol Tax Incentives and Issues, a report prepared by David Andress \& Associates, Inc., under contract with Oak Ridge National Laboratory, April 1998.

Battelle, Gasohol Estimation Model Review, report submitted to Federal Highway Administration, April 30, 1999.

Battelle, Gasohol Estimation Model Review, State Responses to Questionnaire, report submitted to Federal Highway Administration, April 30, 1999.

Department of Agriculture, "Economic Analysis of Replacing MTBE with Ethanol in the United States," http://www.ethanolrfa.org/usda.html, January 2000.

Department of Energy, "Alternative Fuel Vehicle Fleet Buyer's Guide Incentives and Laws," http://www.fleets.doe.gov/fleet_tool.cgi?27519,benefits, 2,3957 .

Department of the Treasury, Internal Revenue Service, official correspondence containing Highway Trust Fund (HTF) certification for processing quarters during various time frames.

Downs, Joe, Ethanol Production Supervisor at A.E. Staley, Loudon, Tennessee, personal communication with Stacy Davis, Oak Ridge National Laboratory, May 20, 2003.

Downstream Alternatives Inc., The Current Fuel Ethanol Industry Transportation, Marketing, Distribution, and Technical Considerations, Phase I Project Report Prepared for Oak Ridge National Laboratory, May 2000.

Downstream Alternatives Inc., Infrastructure Requirements for an Expanded Fuel Ethanol Industry, Phase II Project Report Prepared for Oak Ridge National Laboratory, January 15, 2002.

Energy Information Administration, Petroleum Supply Annual 2001, Volume 1, DOE/EIA-0340(01)/1, June 2002. [Current monthly data available at http://www.eia.doe.gov/oil_gas/petroleum/data_publications/petroleum_supply_mont $\underline{\mathrm{hly} / \mathrm{psm} . \mathrm{html}}$ ]

Energy Information Administration, Petroleum Marketing Annual 2001, DOE/EIA-0487 (2001), September 2002. [Current monthly data available at http://www.eia.doe.gov/oil_gas/petroleum/data_publications/petroleum_marketing_m onthly/pmm.html ]

Energy Information Administration, Supply Impacts of an MTBE Ban, http://tonto.eia.doe.gov/FTPROOT/service/question1.pdf, September 2002. 
Environmental Protection Agency, "Green Book," http://www.epa.gov/oar/oaqps/greenbk/, February 2003.

Environmental Protection Agency, "State Winter Oxygenated Fuel Program Requirements for Attainment or Maintenance of CO NAAQS," http://www.epa.gov/otaq/regs/fuels/oxy-area.pdf.

Environmental Protection Agency, "USA Air Quality Nonattainment Areas," http://www.epa.gov/airs/nonattn.html .

Environmental Protection Agency, "Information on Reformulated Gasoline (RFG) Properties and Emissions Performance by Area and Season - Methodology and Explanation," http://www.epa.gov/otaq/regs/fuels/rfg/properf/perfmeth.htm .

Federal Highway Administration, "The Buck Starts Here, Motor Fuel Attribution: FHWA Estimation of Highway Trust Fund Tax Receipts from Each State," presentation for Gasohol Workshop, February 2003.

Hwang, Ho-Ling, "Summary of the Gasohol Model Improvement Workshop, Held at Washington, DC, January 7, 2003," February 2003.

Jennings, Randy, Tennessee Weights and Measures Office, personal communication with Stacy Davis, Oak Ridge National Laboratory, February 26, 2003.

Lidderdale, Tancred, Energy Information Administration, personal communication with Stacy Davis, Oak Ridge National Laboratory, March 13, 2003.

McCarthy, James E., and Mary Tiemann, "MTBE in Gasoline: Clean Air and Drinking Water Issues," Congressional Research Service Report for Congress, 98-290 ENR, February 2000.

Oak Ridge National Laboratory, Center for Transportation Analysis, "Summary of the Motor Fuel Modeling Workshop, Alexandria, Virginia, on March 7-8, 2002," May 2002.

Oil Price Information Service, Petroleum Terminal Encyclopedia, $14^{\text {th }}$ Edition, http://www.opisnet.com/market/directories/pte.asp, 2002/2003.

Platts, “Alternative to MTBE," http://www.platts.com/features/mtbe/alternative.shtml, N.D.

RFG Survey Association, Inc., "2003 Complex Model RFG Compliance Survey Plan" submitted to the United States Environmental Protection Agency, August 27, 2002.

Renewable Fuels Association, Ethanol Industry Outlook 2001: Clean Air, Clean Water, Clean Fuel, http://www.ethanolrfa.org/rfareport2001.html?NS-search-

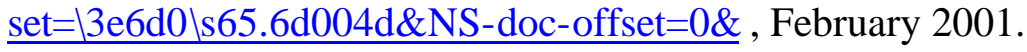


Renewable Fuels Association, "Ethanol Production Facilities," http://www.ethanolrfa.org/eth_prod_fac.html , 2002, [last updated: March 2003].

Romanow, Stuart, Environmental Protection Agency, personal communication with Stacy Davis, Oak Ridge National Laboratory, and transmittal of RFG Survey Data, January 24, 2003.

Shirley, Chuck, Energy Information Administration, Oxygenates Price Master spreadsheet, personal communication with and email to Stacy Davis, Oak Ridge National Laboratory, 2003.

Urbanchuk, John M., "Ability of the U.S. Ethanol Industry to Replace MTBE," AUS Consultants, Moorestown, New Jersey, March 2000. 



\section{APPENDIX A \\ ACRONYMS AND ABBREVIATIONS}

$\begin{array}{ll}\text { CAA } & \text { Clean Air Act } \\ \text { CO } & \text { Carbon Monoxide } \\ \text { CY } & \text { Calendar Year } \\ \text { DOE } & \text { Department of Energy } \\ \text { DOT } & \text { Department of Transportation } \\ \text { EIA } & \text { Energy Information Administration } \\ \text { EPA } & \text { Environmental Protection Agency } \\ \text { ExFIRS } & \text { Excise Files Information Retrieval System } \\ \text { ExSTARS } & \text { Excise Files Summary Terminal Activity Reporting System } \\ \text { FHWA } & \text { Federal Highway Administration } \\ \text { HTF } & \text { Highway Trust Fund } \\ \text { IFTA } & \text { International Fuel Tax Agreement } \\ \text { IM } & \text { Interstate Maintenance } \\ \text { IRS } & \text { Internal Revenue Service } \\ \text { LUST } & \text { Leaking Underground Storage Tank } \\ \text { MTBE } & \text { Methyl Tertiary Butyl Ether } \\ \text { N.D. } & \text { No Date } \\ \text { NHS } & \text { National Highway System } \\ \text { OHPI } & \text { Office of Highway Policy Information } \\ \text { ORNL } & \text { Oak Ridge National Laboratory } \\ \text { OXY } & \text { Oxygenated } \\ \text { PADD } & \text { Petroleum Administration for Defense District } \\ \text { RFA } & \text { Renewable Fuels Association } \\ \text { RFG } & \text { Reformulated Gasoline } \\ \text { STP } & \text { Surface Transportation Program } \\ \text { SAFETEA } & \text { Safe, Accountable, Flexible and Efficient Transportation Equity Act of 2003 } \\ \text { TAME } & \text { Tertiary amyl methyl ether } \\ \text { TEA-21 } & \text { Transportation Equity Act for the 21 }{ }^{\text {st }} \text { Century } \\ \text { U.S. } & \text { United States } \\ \text { USDA } & \text { United States Department of Agriculture } \\ \text { VMT } & \text { Vehicle Miles Traveled } \\ \text { W\&MD } & \text { Weights and Measures Department } \\ & \end{array}$





\section{APPENDIX B \\ EXPLANATIONS OF TERMS}

\section{Ethanol}

A liquid oxygenate and octane enhancer that can be produced biologically from renewable products, such as agricultural crops or wood. When ethanol is used to produce gasohol, care must be exercised during the shipping and blending processes to avoid contact with water.

\section{Gasohol}

A blend of ethyl alcohol (ethanol) and gasoline, in blends containing 5.7\%, 7.7\%, or 10\% ethanol.

\section{Methyl Tertiary Butyl Ether}

An oxygen additive used in RFG. Because MTBE is very soluble in water, environmentalists are concerned about water pollution unless its use as a fuel additive is reduced.

\section{Motor gasoline}

A complex mixture of hydrocarbons, with or without additives, suitable for use in sparkignition engines. It includes "conventional" gasoline, reformulated gasoline, and all types of oxygenated gasoline but not aviation fuel.

\section{Nonattainment area}

An area, such as a city or county, which does not meet the U.S. Environmental Protection Agency's ambient air quality standards for certain pollutants (e.g., carbon monoxide or ozone).

\section{Oxygenate}

An additive blended with conventional motor gasoline to promote cleaner burning of the fuel, thereby reducing production of carbon monoxide.

\section{Reformulated gasoline}

Motor gasoline that meets the requirements of the U.S. Environmental Protection Agency Clean Air Act, Section 211(k). RFG is required in areas where toxins in the air are a problem. In the past, the primary oxygenate additive has been MTBE; in the future, it is expected to be ethanol.

\section{Reformulated gasoline area}

An ozone nonattainment area that requires the use of RFG.

\section{Winter-oxygenated gasoline}

A fuel used in areas where carbon monoxide from car exhausts, especially during winter months, is an issue. 



\section{APPENDIX C \\ DATA SOURCES USED IN THE GASOHOL MODELS}

The two tables below list the actual data sources used in the two gasohol models.

\begin{tabular}{|l|l|l|l|l|}
\hline \multicolumn{1}{|c|}{ Regression-Based Gasohol Model } \\
\hline \multicolumn{1}{|c|}{ Data source } & Data provider & Frequency & $\begin{array}{c}\text { Most } \\
\text { recent } \\
\text { update }\end{array}$ & $\begin{array}{c}\text { Data items or } \\
\text { other remarks }\end{array}$ \\
\hline $\begin{array}{l}\text { http://www.ethanolrf } \\
\text { a.org/index.shtml }\end{array}$ & $\begin{array}{l}\text { Renewable } \\
\text { Fuels } \\
\text { Association }\end{array}$ & annual & 2001 & $\begin{array}{l}\text { U.S. ethanol } \\
\text { production capacity } \\
\text { by company; ethanol } \\
\text { incentives by State }\end{array}$ \\
\hline Form FHWA-551M & FHWA & annual & 2002 & $\begin{array}{l}\text { State reported } \\
\text { gasohol and total } \\
\text { gasoline data }\end{array}$ \\
\hline $\begin{array}{l}\text { IRS tax revenue and } \\
\text { tax rates data }\end{array}$ & IRS & annual & 2002 & $\begin{array}{l}\text { Total gasohol and } \\
\text { ethanol tax revenue } \\
\text { for U.S. }\end{array}$ \\
\hline $\begin{array}{l}\text { The Clean Fuels } \\
\text { Report }\end{array}$ & $\begin{array}{l}\text { J.E. Sinor } \\
\text { Consultants Inc. }\end{array}$ & annual & 2001 & $\begin{array}{l}\text { Ethanol incentives by } \\
\text { State }\end{array}$ \\
\hline $\begin{array}{l}\text { Nonattainment areas } \\
\text { data }\end{array}$ & EPA & 1999 & $\begin{array}{l}\text { Use of gasohol as } \\
\text { and VMT level of blends, } \\
\text { data quality, etc. }\end{array}$ \\
\hline $\begin{array}{l}\text { State responses to } \\
\text { gasohol questionnaire }\end{array}$ & Battelle report & once & & \\
\hline
\end{tabular}




\begin{tabular}{|c|c|c|c|c|}
\hline \multicolumn{5}{|c|}{ Rule-Based Gasohol Model } \\
\hline Data source & $\begin{array}{c}\text { Data } \\
\text { provider }\end{array}$ & Frequency & $\begin{array}{c}\text { Most } \\
\text { recent } \\
\text { update }\end{array}$ & $\begin{array}{l}\text { Data items or } \\
\text { other remarks }\end{array}$ \\
\hline Form FHWA-551M & FHWA & annual & 2002 & $\begin{array}{l}\text { State reported } \\
\text { gasohol and total } \\
\text { gasoline data }\end{array}$ \\
\hline $\begin{array}{l}\text { IRS tax revenue and } \\
\text { tax rates data }\end{array}$ & IRS & annual & 2002 & $\begin{array}{l}\text { Total gasohol and } \\
\text { ethanol tax revenue } \\
\text { for U.S. }\end{array}$ \\
\hline $\begin{array}{l}\text { Petroleum Marketing } \\
\text { Annual }\end{array}$ & EIA & annual & 2002 & $\begin{array}{l}\text { Supplier sales of } \\
\text { oxygenated fuel and } \\
\text { RFG by State }\end{array}$ \\
\hline $\begin{array}{l}\text { Highway Statistics } \\
\text { Table MF-121T }\end{array}$ & FHWA & annual & 2001 & $\begin{array}{l}\text { Gasohol fuel tax } \\
\text { exemptions }\end{array}$ \\
\hline $\begin{array}{l}\text { State Winter } \\
\text { Oxygenate Fuel } \\
\text { Program data }\end{array}$ & EPA & annual & 2001 & $\begin{array}{l}\text { Oxygen content and } \\
\text { type of oxygenate } \\
\text { used in each area }\end{array}$ \\
\hline RFG Survey Data & EPA & annual & 2002 & $\begin{array}{l}\text { Share of RFG which } \\
\text { uses ethanol/MTBE } \\
\text { and at what volume }\end{array}$ \\
\hline $\begin{array}{l}\text { State Weights \& } \\
\text { Measures Office } \\
\text { contacts }\end{array}$ & ORNL & Once & 2002 & $\begin{array}{l}\text { "Zero State" } \\
\text { confirmation }\end{array}$ \\
\hline $\begin{array}{l}\text { http://www.ethanolrfa. } \\
\text { org/index.shtml }\end{array}$ & $\begin{array}{l}\text { Renewable } \\
\text { Fuels } \\
\text { Association }\end{array}$ & annual & 2003 & $\begin{array}{l}\text { U.S. ethanol } \\
\text { production capacity } \\
\text { by company; ethanol } \\
\text { incentives by State }\end{array}$ \\
\hline
\end{tabular}




\section{APPENDIX D \\ NOTES FROM CONTACTS WITH STATE WEIGHTS AND MEASURES PROGRAMS AND OTHER STATE INFORMATION SOURCES}

AL-Said that approximately $1 \%$ of gasoline samples taken were gasohol.

$\mathrm{AR}$ - State testing program said that there is definitely no gasohol in the State. No companies are registered to sell gasohol.

AZ - State testing program said that there is no gasohol used outside of the mandated Winter Oxy areas.

CT-There is no conventional gasoline sold in the State.

DC-There is no fuel testing program in the District. There is no conventional gasoline sold in the State.

DE-There is no fuel testing program in the State. There is no conventional gasoline sold in the State.

FL-State report shows monthly gasohol use (gallons) from 1981-2000. State testing program indicated that the only terminal that carried gasohol within the State notified them in 2003 that they would no longer carry gasohol. So after 2003 FL should be a zero state.

GA-State testing program said there is no gasohol in the State.

$\mathrm{HI}$ - State testing program said there is no gasohol in the State.

ID-State testing program said that gasohol was prevalent in small quantities throughout the State.

$\mathrm{KS}$ - There is no evidence from the State website that they can separate gasohol from gasoline data.

MA-There is no conventional gasoline sold in the State.

MD-There is no fuel testing program in the State. Data on State website indicates that they are a zero State. According to FHWA, they use some.

ME-There is no fuel testing program in the State, but they do not believe there is any gasohol in the State (they would see it when they test the pumps).

MI-State website indicates that gasohol sales in the state are increasing (2002 estimate of 80 million gallons of ethanol.) (www.michigan.gov/mda)

MS-State testing program said that there is no gasohol in the State.

$\mathrm{NC}$ - State testing program said that there had been no fuel samples of gasohol in over a year. A terminal in Greensboro used to carry it, but they quit last year and now there is no gasohol in NC.

ND-State website shows annual gasohol tax dollars in State Tax Commissioner's Biennial Report (http://www.state.nd.us/taxdpt/genpubs/45thbiennialreport.pdf )

NE-State website shows monthly gasohol use (dollars and gallons) from 1999-2002 (www.revenue.state.ne.us/fuels/stats.htm)

$\mathrm{NH}-$ There is no fuel testing program in the State.

$\mathrm{NJ}-$ There is no conventional gasoline sold in the State.

$\mathrm{NM}$ - State testing program said that there is no gasohol used outside of the mandated Winter Oxy Areas.

NY-State testing program said that gasohol was sold in 186 out of 6,400 stations. It is sold in the areas of Buffalo, Rochester, and the lower Hudson Valley. 
PA-There is no fuel testing program in the State. No idea if gasohol is used or not. No evidence on PA website that gasoline can be separated from gasohol.

$\mathrm{RI}-$ There is no fuel testing program in the State. There is no conventional gasoline sold in the State.

$\mathrm{SC}$ - State testing program said there is no gasohol in the State.

$\mathrm{TN}$-State testing program said there is no gasohol in the State. Ethanol made in TN is used elsewhere.

TX - State testing program said they don't use much gasohol at all.

UT-Gasohol is not used outside the Winter Oxy Area.

VA-State testing program said that there is not much gasohol outside RFG area. There is no evidence from the State website that they can separate gasohol from gasoline data.

VT-There is no fuel testing program in the State.

WA-State testing program said that there were outlets around the State that sell gasohol year round, but the Winter Oxy area goes back to conventional gasoline in the summer.

WV-There is no evidence from the State website that they can separate gasohol from gasoline data. 


\section{APPENDIX E SENSITIVITY ANALYSIS}

ORNL tested several assumptions used in the gasohol model to investigate what effect a change might have on the final State shares. Eight scenarios were evaluated against the base case scenario.

Differences between results from the base case and each of the scenarios are documented in this Appendix.

Three scenarios involving proximity to an ethanol production plant are shown in Table E.1. The changes of the "100 miles from an ethanol plant" to 150 or 200 miles have no impacts on the State shares. Though changing to 250 miles has some impact, the map shows that almost all States are touched, with the exception of Louisiana and the New England States.

Scenarios 5 through 9 on Tables E. 2 and E. 3 are designed to evaluate the sensitivity of varying the "likelihood" weights used in the rule-based gasohol model.

If a State is categorized as a "partially allocated" State, under the base scenario, it received a weight of 0.1 for the "likelihood of ethanol use." The value was changed to 0.2 under scenarios 5,8 , and 9 .

If a State is within 100 miles of an ethanol plant, it was given a weight of 1.5 in the "likelihood of ethanol use" column under the base case scenario. This value was changed to 1.2 under scenarios 6 and 9, and changed to 2.0 under scenarios 7 and 8 .

Note that none of these results included any extra MTBE estimates. Also, the ethanol plant in Tennessee was excluded from the "100 miles from an ethanol plant" criteria due to the fact that the ethanol made in Tennessee is not used for gasohol anywhere in the South (see Section 5.3.6 for details). 
Table E.1. Results from scenarios 2-4

Analysis Year: 2001

Difference from Base Case

\begin{tabular}{|c|c|c|c|c|c|c|c|}
\hline State & Base Case & Scenario 2 & Scenario 3 & Scenario 4 & Scenario 2 & Scenario 3 & Scenario 4 \\
\hline Alabama & $1.54 \%$ & $1.54 \%$ & $1.54 \%$ & $1.34 \%$ & & & $-0.21 \%$ \\
\hline Alaska & $0.26 \%$ & $0.26 \%$ & $0.26 \%$ & $0.26 \%$ & & & \\
\hline Arizona & $0.73 \%$ & $0.73 \%$ & $0.73 \%$ & $0.73 \%$ & & & \\
\hline Arkansas & $0.00 \%$ & $0.00 \%$ & $0.00 \%$ & $0.00 \%$ & & & \\
\hline California & $9.06 \%$ & $9.06 \%$ & $9.06 \%$ & $9.06 \%$ & & & \\
\hline Colorado & $3.41 \%$ & $3.41 \%$ & $3.41 \%$ & $3.40 \%$ & & & $-0.01 \%$ \\
\hline Connecticut & $0.06 \%$ & $0.06 \%$ & $0.06 \%$ & $0.06 \%$ & & & \\
\hline Delaware & $0.00 \%$ & $0.00 \%$ & $0.00 \%$ & $0.00 \%$ & & & \\
\hline District of Columbia & $0.00 \%$ & $0.00 \%$ & $0.00 \%$ & $0.00 \%$ & & & \\
\hline Florida & $0.05 \%$ & $0.05 \%$ & $0.05 \%$ & $0.05 \%$ & & & \\
\hline Georgia & $0.00 \%$ & $0.00 \%$ & $0.00 \%$ & $0.00 \%$ & & & \\
\hline Hawaii & $0.00 \%$ & $0.00 \%$ & $0.00 \%$ & $0.00 \%$ & & & \\
\hline Idaho & $0.00 \%$ & $0.00 \%$ & $0.00 \%$ & $0.00 \%$ & & & \\
\hline Illinois & $15.26 \%$ & $15.26 \%$ & $15.26 \%$ & $15.26 \%$ & & & \\
\hline Indiana & $5.11 \%$ & $5.11 \%$ & $5.11 \%$ & $5.11 \%$ & & & \\
\hline Iowa & $4.51 \%$ & $4.51 \%$ & $4.51 \%$ & $4.51 \%$ & & & \\
\hline Kansas & $1.24 \%$ & $1.24 \%$ & $1.24 \%$ & $1.07 \%$ & & & $-0.17 \%$ \\
\hline Kentucky & $1.05 \%$ & $1.05 \%$ & $1.05 \%$ & $1.04 \%$ & & & $-0.01 \%$ \\
\hline Louisiana & $1.45 \%$ & $1.45 \%$ & $1.45 \%$ & $1.25 \%$ & & & $-0.19 \%$ \\
\hline Maine & $0.00 \%$ & $0.00 \%$ & $0.00 \%$ & $0.00 \%$ & & & \\
\hline Maryland & $1.59 \%$ & $1.59 \%$ & $1.59 \%$ & $1.38 \%$ & & & $-0.21 \%$ \\
\hline Massachusetts & $0.23 \%$ & $0.23 \%$ & $0.23 \%$ & $0.23 \%$ & & & \\
\hline Michigan & $4.78 \%$ & $4.78 \%$ & $4.78 \%$ & $4.14 \%$ & & & $-0.64 \%$ \\
\hline Minnesota & $13.84 \%$ & $13.84 \%$ & $13.84 \%$ & $13.84 \%$ & & & \\
\hline Mississippi & $0.00 \%$ & $0.00 \%$ & $0.00 \%$ & $0.00 \%$ & & & \\
\hline Missouri & $1.22 \%$ & $1.22 \%$ & $1.22 \%$ & $1.22 \%$ & & & \\
\hline Montana & $0.07 \%$ & $0.07 \%$ & $0.07 \%$ & $0.07 \%$ & & & \\
\hline Nebraska & $1.24 \%$ & $1.24 \%$ & $1.24 \%$ & $1.24 \%$ & & & \\
\hline Nevada & $1.43 \%$ & $1.43 \%$ & $1.43 \%$ & $1.43 \%$ & & & \\
\hline New Hampshire & $0.00 \%$ & $0.00 \%$ & $0.00 \%$ & $0.00 \%$ & & & \\
\hline New Jersey & $0.06 \%$ & $0.06 \%$ & $0.06 \%$ & $0.06 \%$ & & & \\
\hline New Mexico & $0.58 \%$ & $0.58 \%$ & $0.58 \%$ & $0.58 \%$ & & & \\
\hline New York & $0.20 \%$ & $0.20 \%$ & $0.20 \%$ & $0.18 \%$ & & & $-0.02 \%$ \\
\hline North Carolina & $2.66 \%$ & $2.66 \%$ & $2.66 \%$ & $2.31 \%$ & & & $-0.36 \%$ \\
\hline North Dakota & $0.35 \%$ & $0.35 \%$ & $0.35 \%$ & $0.35 \%$ & & & \\
\hline Ohio & $9.62 \%$ & $9.62 \%$ & $9.62 \%$ & $9.62 \%$ & & & \\
\hline Oklahoma & $0.00 \%$ & $0.00 \%$ & $0.00 \%$ & $0.00 \%$ & & & \\
\hline Oregon & $2.05 \%$ & $2.05 \%$ & $2.05 \%$ & $2.04 \%$ & & & $-0.01 \%$ \\
\hline Pennsylvania & $3.23 \%$ & $3.23 \%$ & $3.23 \%$ & $4.20 \%$ & & & $0.97 \%$ \\
\hline Rhode Island & $0.03 \%$ & $0.03 \%$ & $0.03 \%$ & $0.03 \%$ & & & \\
\hline South Carolina & $0.00 \%$ & $0.00 \%$ & $0.00 \%$ & $0.00 \%$ & & & \\
\hline South Dakota & $1.01 \%$ & $1.01 \%$ & $1.01 \%$ & $1.01 \%$ & & & \\
\hline Tennessee & $0.00 \%$ & $0.00 \%$ & $0.00 \%$ & $0.00 \%$ & & & \\
\hline Texas & $1.62 \%$ & $1.62 \%$ & $1.62 \%$ & $1.62 \%$ & & & \\
\hline Utah & $0.26 \%$ & $0.26 \%$ & $0.26 \%$ & $0.26 \%$ & & & \\
\hline Vermont & $0.00 \%$ & $0.00 \%$ & $0.00 \%$ & $0.00 \%$ & & & \\
\hline Virginia & $2.42 \%$ & $2.42 \%$ & $2.42 \%$ & $3.15 \%$ & & & $0.73 \%$ \\
\hline Washington & $3.45 \%$ & $3.45 \%$ & $3.45 \%$ & $3.43 \%$ & & & $-0.02 \%$ \\
\hline West Virginia & $0.53 \%$ & $0.53 \%$ & $0.53 \%$ & $0.69 \%$ & & & $0.16 \%$ \\
\hline Wisconsin & $3.79 \%$ & $3.79 \%$ & $3.79 \%$ & $3.79 \%$ & & & \\
\hline Wyoming & $0.00 \%$ & $0.00 \%$ & $0.00 \%$ & $0.00 \%$ & & & \\
\hline Total & $100.00 \%$ & $100.00 \%$ & $100.00 \%$ & $100.00 \%$ & & & \\
\hline \multicolumn{8}{|c|}{ 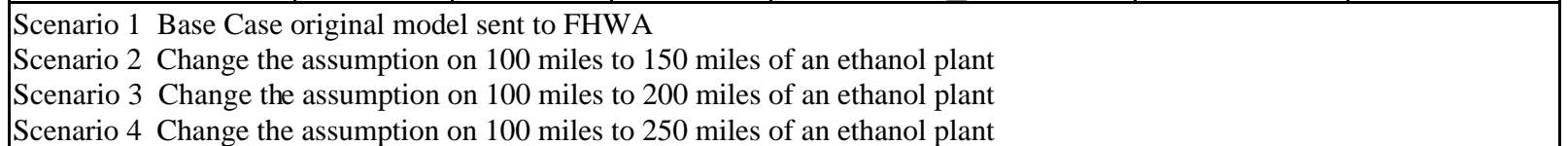 } \\
\hline
\end{tabular}


Table E.2. Results from scenarios 5-9

Analysis Year: 2001

\begin{tabular}{|c|c|c|c|c|c|c|}
\hline State & Base Case & Scenario 5 & Scenario 6 & Scenario 7 & Scenario 8 & Scenario 9 \\
\hline Alabama & $1.54 \%$ & $1.50 \%$ & $1.64 \%$ & $1.40 \%$ & $1.37 \%$ & $1.60 \%$ \\
\hline Alaska & $0.26 \%$ & $0.26 \%$ & $0.26 \%$ & $0.26 \%$ & $0.26 \%$ & $0.26 \%$ \\
\hline Arizona & $0.73 \%$ & $0.73 \%$ & $0.73 \%$ & $0.73 \%$ & $0.73 \%$ & $0.73 \%$ \\
\hline Arkansas & $0.00 \%$ & $0.00 \%$ & $0.00 \%$ & $0.00 \%$ & $0.00 \%$ & $0.00 \%$ \\
\hline California & $9.06 \%$ & $9.06 \%$ & $9.06 \%$ & $9.06 \%$ & $9.06 \%$ & $9.06 \%$ \\
\hline Colorado & $3.41 \%$ & $3.49 \%$ & $3.41 \%$ & $3.40 \%$ & $3.48 \%$ & $3.50 \%$ \\
\hline Connecticut & $0.06 \%$ & $0.06 \%$ & $0.06 \%$ & $0.06 \%$ & $0.06 \%$ & $0.06 \%$ \\
\hline Delaware & $0.00 \%$ & $0.00 \%$ & $0.00 \%$ & $0.00 \%$ & $0.00 \%$ & $0.00 \%$ \\
\hline District of Columbia & $0.00 \%$ & $0.00 \%$ & $0.00 \%$ & $0.00 \%$ & $0.00 \%$ & $0.00 \%$ \\
\hline Florida & $0.05 \%$ & $0.05 \%$ & $0.05 \%$ & $0.05 \%$ & $0.05 \%$ & $0.05 \%$ \\
\hline Georgia & $0.00 \%$ & $0.00 \%$ & $0.00 \%$ & $0.00 \%$ & $0.00 \%$ & $0.00 \%$ \\
\hline Hawaii & $0.00 \%$ & $0.00 \%$ & $0.00 \%$ & $0.00 \%$ & $0.00 \%$ & $0.00 \%$ \\
\hline Idaho & $0.00 \%$ & $0.00 \%$ & $0.00 \%$ & $0.00 \%$ & $0.00 \%$ & $0.00 \%$ \\
\hline Illinois & $15.26 \%$ & $15.26 \%$ & $15.26 \%$ & $15.26 \%$ & $15.26 \%$ & $15.26 \%$ \\
\hline Indiana & $5.11 \%$ & $5.11 \%$ & $5.11 \%$ & $5.11 \%$ & $5.11 \%$ & $5.11 \%$ \\
\hline Iowa & $4.51 \%$ & $4.51 \%$ & $4.51 \%$ & $4.51 \%$ & $4.51 \%$ & $4.51 \%$ \\
\hline Kansas & $1.24 \%$ & $1.20 \%$ & $1.05 \%$ & $1.50 \%$ & $1.46 \%$ & $1.02 \%$ \\
\hline Kentucky & $1.05 \%$ & $1.15 \%$ & $1.06 \%$ & $1.04 \%$ & $1.13 \%$ & $1.16 \%$ \\
\hline Louisiana & $1.45 \%$ & $1.41 \%$ & $1.54 \%$ & $1.31 \%$ & $1.28 \%$ & $1.49 \%$ \\
\hline Maine & $0.00 \%$ & $0.00 \%$ & $0.00 \%$ & $0.00 \%$ & $0.00 \%$ & $0.00 \%$ \\
\hline Maryland & $1.59 \%$ & $1.55 \%$ & $1.69 \%$ & $1.44 \%$ & $1.41 \%$ & $1.64 \%$ \\
\hline Massachusetts & $0.23 \%$ & $0.23 \%$ & $0.23 \%$ & $0.23 \%$ & $0.23 \%$ & $0.23 \%$ \\
\hline Michigan & $4.78 \%$ & $4.65 \%$ & $4.07 \%$ & $5.79 \%$ & $5.65 \%$ & $3.95 \%$ \\
\hline Minnesota & $13.84 \%$ & $13.84 \%$ & $13.84 \%$ & $13.84 \%$ & $13.84 \%$ & $13.84 \%$ \\
\hline Mississippi & $0.00 \%$ & $0.00 \%$ & $0.00 \%$ & $0.00 \%$ & $0.00 \%$ & $0.00 \%$ \\
\hline Missouri & $1.22 \%$ & $1.22 \%$ & $1.22 \%$ & $1.22 \%$ & $1.22 \%$ & $1.22 \%$ \\
\hline Montana & $0.07 \%$ & $0.07 \%$ & $0.07 \%$ & $0.07 \%$ & $0.07 \%$ & $0.07 \%$ \\
\hline Nebraska & $1.24 \%$ & $1.24 \%$ & $1.24 \%$ & $1.24 \%$ & $1.24 \%$ & $1.24 \%$ \\
\hline Nevada & $1.43 \%$ & $1.43 \%$ & $1.43 \%$ & $1.43 \%$ & $1.43 \%$ & $1.43 \%$ \\
\hline New Hampshire & $0.00 \%$ & $0.00 \%$ & $0.00 \%$ & $0.00 \%$ & $0.00 \%$ & $0.00 \%$ \\
\hline New Jersey & $0.06 \%$ & $0.06 \%$ & $0.06 \%$ & $0.06 \%$ & $0.06 \%$ & $0.06 \%$ \\
\hline New Mexico & $0.58 \%$ & $0.58 \%$ & $0.58 \%$ & $0.58 \%$ & $0.58 \%$ & $0.58 \%$ \\
\hline New York & $0.20 \%$ & $0.35 \%$ & $0.21 \%$ & $0.18 \%$ & $0.32 \%$ & $0.37 \%$ \\
\hline North Carolina & $2.66 \%$ & $2.59 \%$ & $2.84 \%$ & $2.42 \%$ & $2.36 \%$ & $2.75 \%$ \\
\hline North Dakota & $0.35 \%$ & $0.35 \%$ & $0.35 \%$ & $0.35 \%$ & $0.35 \%$ & $0.35 \%$ \\
\hline Ohio & $9.62 \%$ & $9.62 \%$ & $9.62 \%$ & $9.62 \%$ & $9.62 \%$ & $9.62 \%$ \\
\hline Oklahoma & $0.00 \%$ & $0.00 \%$ & $0.00 \%$ & $0.00 \%$ & $0.00 \%$ & $0.00 \%$ \\
\hline Oregon & $2.05 \%$ & $2.12 \%$ & $2.05 \%$ & $2.04 \%$ & $2.10 \%$ & $2.12 \%$ \\
\hline Pennsylvania & $3.23 \%$ & $3.15 \%$ & $3.44 \%$ & $2.94 \%$ & $2.87 \%$ & $3.34 \%$ \\
\hline Rhode Island & $0.03 \%$ & $0.03 \%$ & $0.03 \%$ & $0.03 \%$ & $0.03 \%$ & $0.03 \%$ \\
\hline South Carolina & $0.00 \%$ & $0.00 \%$ & $0.00 \%$ & $0.00 \%$ & $0.00 \%$ & $0.00 \%$ \\
\hline South Dakota & $1.01 \%$ & $1.01 \%$ & $1.01 \%$ & $1.01 \%$ & $1.01 \%$ & $1.01 \%$ \\
\hline Tennessee & $0.00 \%$ & $0.00 \%$ & $0.00 \%$ & $0.00 \%$ & $0.00 \%$ & $0.00 \%$ \\
\hline Texas & $1.62 \%$ & $1.62 \%$ & $1.62 \%$ & $1.62 \%$ & $1.62 \%$ & $1.62 \%$ \\
\hline Utah & $0.26 \%$ & $0.26 \%$ & $0.26 \%$ & $0.26 \%$ & $0.26 \%$ & $0.26 \%$ \\
\hline Vermont & $0.00 \%$ & $0.00 \%$ & $0.00 \%$ & $0.00 \%$ & $0.00 \%$ & $0.00 \%$ \\
\hline Virginia & $2.42 \%$ & $2.36 \%$ & $2.58 \%$ & $2.20 \%$ & $2.15 \%$ & $2.51 \%$ \\
\hline Washington & $3.45 \%$ & $3.58 \%$ & $3.46 \%$ & $3.44 \%$ & $3.55 \%$ & $3.59 \%$ \\
\hline West Virginia & $0.53 \%$ & $0.51 \%$ & $0.56 \%$ & $0.48 \%$ & $0.47 \%$ & $0.55 \%$ \\
\hline Wisconsin & $3.79 \%$ & $3.79 \%$ & $3.79 \%$ & $3.79 \%$ & $3.79 \%$ & $3.79 \%$ \\
\hline Wyoming & $0.00 \%$ & $0.00 \%$ & $0.00 \%$ & $0.00 \%$ & $0.00 \%$ & $0.00 \%$ \\
\hline Total & $100.00 \%$ & $100.00 \%$ & $100.00 \%$ & $100.00 \%$ & $100.00 \%$ & $100.00 \%$ \\
\hline
\end{tabular}

Scenario 5 Change the partially allocated State assumption to 0.2 instead of 0.1

Scenario 6 Change the within 100 miles of ethanol plant assumption to 1.2 instead of 1.5

Scenario 7 Change the within 100 miles of ethanol plant assumption to 2 instead of 1.5

Scenario 8 Change the partially allocated State assumption to 0.2 instead of 0.1 and change the within 100 miles of ethanol plant assumption to 2 instead of 1.5

Scenario 9 Change the partially allocated State assumption to 0.2 instead of 0.1 and change the within 100 miles of ethanol plant assumption to 1.2 instead of 1.5 
Table E.2 Results from Scenarios 5-9 (Continued)

Analysis Year: 2001

Difference from Base Case

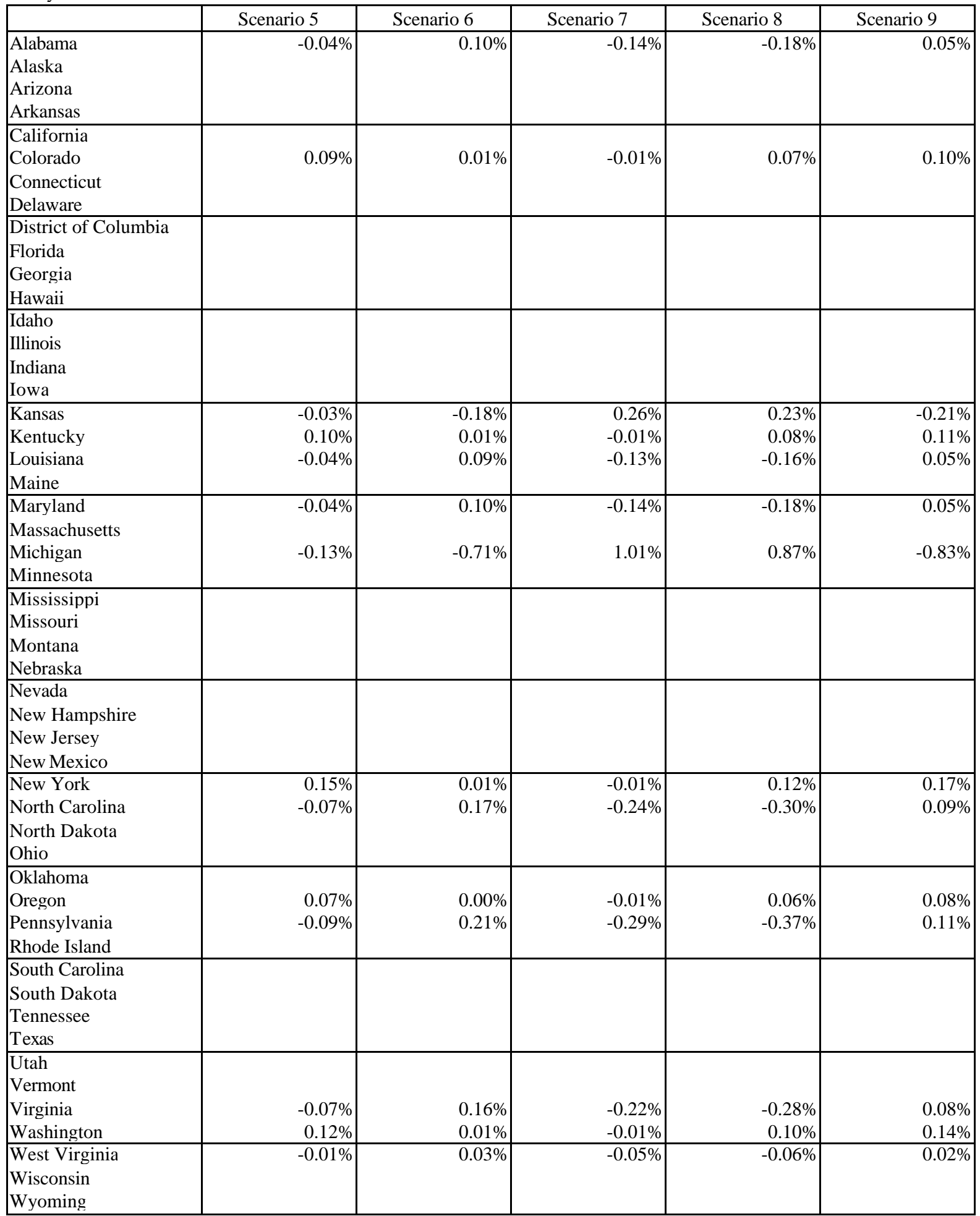

Scenario 5 Change the partially allocated State assumption to 0.2 instead of 0.1

Scenario 6 Change the within 100 miles of ethanol plant assumption to 1.2 instead of 1.5

Scenario 7 Change the within 100 miles of ethanol plant assumption to 2 instead of 1.5

Scenario 8 Change the partially allocated State assumption to 0.2 instead of 0.1 and change the within 100 miles of ethanol plant assumption to 2 instead of 1.5

Scenario 9 Change the partially allocated State assumption to 0.2 instead of 0.1 and change the within 100 miles of ethanol plant assumption to 1.2 instead of 1.5 


\section{INTERNAL DISTRIBUTION}

1. Stacy Davis

2. Pat $\mathrm{Hu}$

3. Ho-Ling Hwang

4. Lorena Truett
5. Central Research Library

6. ORNL Laboratory Records-RC

7. ORNL Laboratory Records-OSTI

\section{EXTERNAL DISTRIBUTION}

8-11. Ralph Erickson, U.S. Department of Transportation, Office of Highway Policy Information, 400 Seventh Street, S. W., Washington, D.C. 20590.

12. Tom Howard, U.S. Department of Transportation, Office of Highway Policy Information, 400 Seventh Street, S. W., Washington, D.C. 20590. 